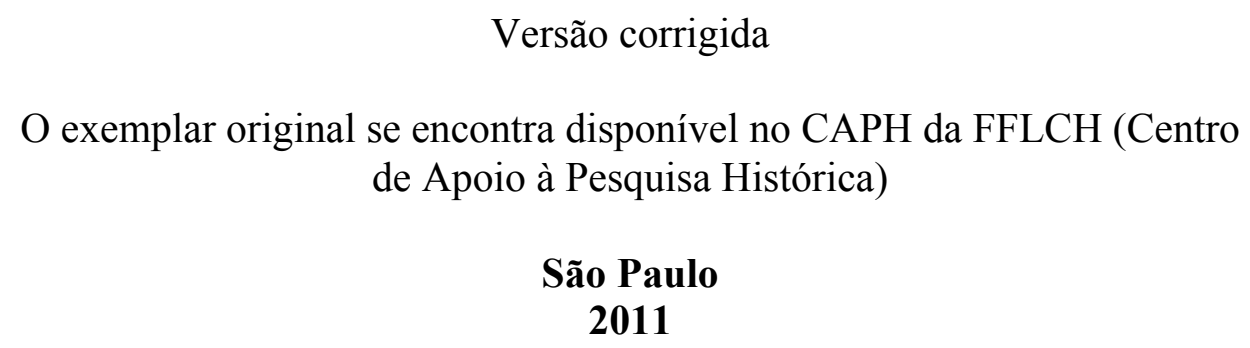




\title{
MAIORIAS, MINORIAS E OPOSIÇÃO: PARTICIPAÇÃO LEGISLATIVA NO PRESIDENCIALSMO DE COALIZÃO BRASILEIRO
}

Dissertação apresentada à Faculdade de Filosofia Letras e Ciências Humanas da Universidade de São Paulo para obtenção do Título de Mestre em Ciência Política

Orientador: Prof. Dr. Fernando Limongi

\author{
Versão corrigida \\ O exemplar original se encontra disponível no CAPH da FFLCH (Centro \\ de Apoio à Pesquisa Histórica) \\ São Paulo \\ 2011
}


Nome: MOURA, Samuel

Título: Maiorias, minorias e oposição: participação legislativa no presidencialismo de coalizão brasileiro.

Dissertação apresentada à

Faculdade Filosofia Letras e Ciências Humanas da

Universidade de São Paulo para obtenção do

título de Mestre em Ciência Política

Aprovado em:

Banca Examinadora

Prof. Dr.

Instituição:

Julgamento:

Assinatura:

Prof. Dr.

Instituição:

Julgamento:

Assinatura:

Prof. Dr.

Instituição:

Julgamento:

Assinatura: 
Para meu pai, Luiz. 


\section{Agradecimentos}

Ao meu pai, presente em todas as etapas da minha vida. À minha mãe. Ao Rafael Freitas, pelo incentivo, um amigo e companheiro de todas as jornadas. Ao professor Fernando Limongi, pela paciência e carinho. À minha Tia Marli, com toda compreensão, uma voz sabia de todos os momentos. À Jaqueline Zulini, um grande coração. Ao Dan Buscatto, pela sinceridade e apoio, das dez às dez. À Andréa Freitas, pela dedicação à ciência e aos seus pupilos, que nos serve de exemplo. Ao Centro Brasileiro de Análise e Planejamento (CEBRAP), minha segunda casa, e a todos amigos que lá fiz e me possibilitaram chegar até aqui. À professora Argelina Figueiredo, que me deu a oportunidade de ingressar no Cebrap. Ao Sérgio Simoni pela atenção e bem querer. Ao grupo de estudos Legislativos, ao Maurício Isumi, Samir de Luna e à Fernanda Machado. À Flávia Bolochuvas pelo apoio constante, entre tortas e tabelas.

À Capes pelo apoio à pesquisa. Ao Departamento de Ciências Políticas; à Rai, ao Vasne e a toda aquelas pessoas que contribuíram para que esse trabalho fosse possível, por vezes até mesmo em uma conversa de bar. 
MOURA, SAMUEL Maiorias, minorias e oposição: participação legislativa no presidencialismo de coalizão brasileiro. 2011, 87 p. Dissertação de Mestrado - Faculdade de Filosofia, Letras e Ciências Humanas, Universidade de São Paulo, São Paulo.

\section{Resumo}

Esta dissertação pretende discutir como se dá, em termos propositivos, a participação daqueles atores que se situam fora da coalizão ministerial de governo. Tendo por objeto a produção das leis, propõem-se observar como se resolvem institucionalmente os conflitos. Tomando por base que Presidentes buscam formar coalizões que contam com a maioria das cadeiras do parlamento - medida suficiente, em teoria, para aprovar sua agenda de governo - pretende-se questionar em que grau se dá a participação da minoria e daqueles atores que não fazem parte da coalizão de governo. Para tanto, faremos um contraponto com os governos minoritários, comparando as chances de participação efetiva dos dois blocos, em termos proporcionais, ou seja, em relação ao número de cadeiras que ocupam. O trabalho mostra como a participação dos atores que se situam fora da coalizão de governo pode indicar a existência de um consenso legislativo que extrapola os limites dos partidos que compõem o governo, independente deste compor coalizões majoritárias ou não - se estendendo até mesmo aos partidos tidos como de oposição. Ao final do trabalho, mostrarei como esses partidos, normalmente tidos como de oposição, também participam do processo de formulação das políticas. Pretende-se aqui suprir a lacuna deixada pela literatura especializada que, ao voltar seu foco de preocupação para a governabilidade do sistema presidencialista deixa a descoberto a participação positiva daqueles atores que não compõem a coalizão de governo.

Palavras-chave: relações entre Executivo e Legislativo, coalizões, minoria legislativa, oposição, participação, consensualismo, consociativismo. 
MOURA SAMUEL. Majorities, minorities and opposition: legislative participation in the Brazilian coalitional presidentialism. 2011, 87 p. Dissertação de Mestrado - Faculdade de Filosofia, Letras e Ciências Humanas, Universidade de São Paulo, São Paulo.

This dissertation intends to discuss, in propositional terms, the participation of those actors who are outside the ministerial coalition of the Brazilian government. With the focus on the production of laws, we propose to observe how institutional conflicts are solved. Considering that Presidents seek to form coalitions as a way to have a majority of seats in Parliament - a sufficient measure, in theory, to approve the governmental agenda - we question to what extent the minority and those actors that are outside of the government coalition are able to participate in this process. To this end, we contrast majority and minority governments, comparing the chances of effective participation of the two blocks, in proportional terms, which means taking into account the number of seats occupied by each side. The work shows how the participation of those actors who are outside the governmental coalition can indicate the existence of a legislative consensus that is bigger than the sum of the political parties that are members of the government coalition, regardless of the fact that this is a majority coalition or not - extending itself to parties that are regarded as opposition. At the end of the work, we show how the parties usually taken as the opposition are also able to participate in the formulation of policies. The intention here is to fill a gap left by the literature that, focusing on the success of presidential system of governance does not take into account the positive participation of those actors positioned outside the government coalition.

Key-words: Executive and Legislative relations, coalitions, legislative minority, opposition, participation, consociativism. 


\section{Lista de tabelas}

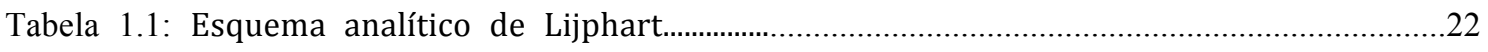

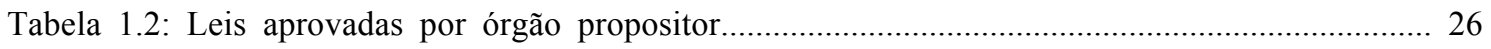

Tabela 1.3: Taxa de sucesso e dominância do Executivo.............................................................. 27

Tabela 1.4: Produção legal do Executivo, por tipo de lei e por governo........................................ 28

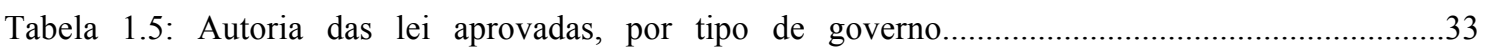

Tabela 1.6: Autoria de projetos de iniciativa compartilhada, por tipo de governo............................ 34

Tabela 2.1: Relatorias válidas nas leis aprovadas, por tipo de governo........................................ 47

Tabela 2.2: Média da proporção das cadeiras CD/SF ..................................................................... 48

Tabela 2.3: Relatorias válidas nas leis de iniciativa privativa do Executivo, por tipo de governo........... 51

Tabela 2.4: Relatorias válidas nas leis de iniciativa compartilhada, por tipo de governo..................... 51

Tabela 2.5: Relatorias válidas nas leis de autoria da não-coalizão, por tipo de governo 52

Tabela 2.6: Alterações nas leis aprovadas, por tipo de governo............................................ 57

Tabela 2.7: Alterações nas leis de iniciativa privativa do Executivo, por tipo de governo..................... 58

Tabela 2.8: Alterações nas leis de iniciativa compartilhada, por tipo de governo................................... 59

Tabela 2.9: Alterações nas leis da não-coalizão, por tipo de governo..................................... 59

Tabela 3.1: Coalizão vence com as próprias forças?................................................................ 79

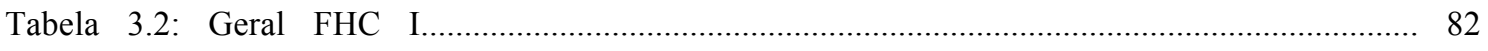

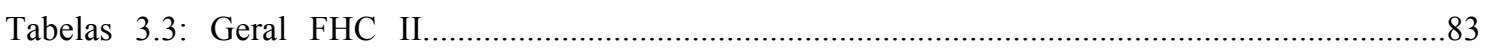

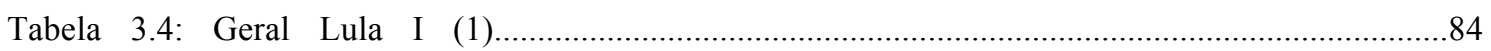

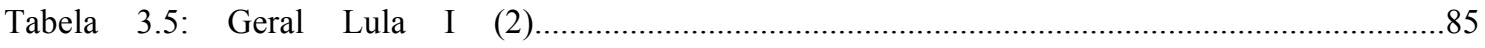

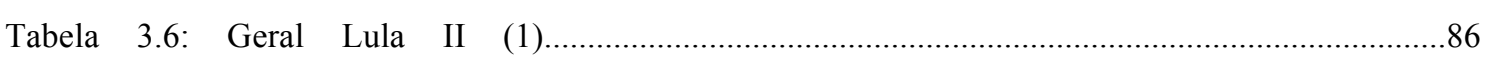

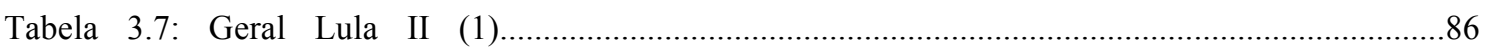

\section{Lista de gráficos}

Gráfico 1.1: Iniciativa compartilhada da não-coalizão vs. \% de cadeiras da não-coalizão....................... 36

Gráfico 2.1: Relatorias válidas da não-coalizão vs. \% cadeiras da não-coalizão...................................... 53

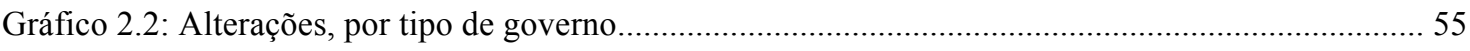

Gráfico 2.3: Alterações da não-coalizão vs \% cadeiras da não-coalizão..................................................60

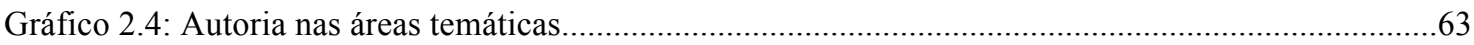

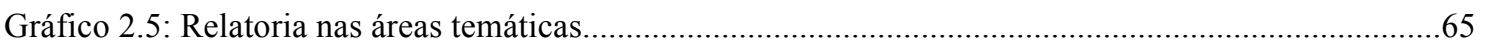

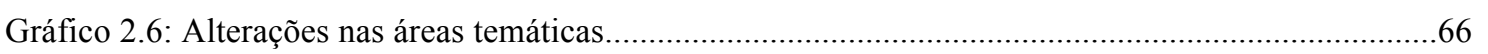

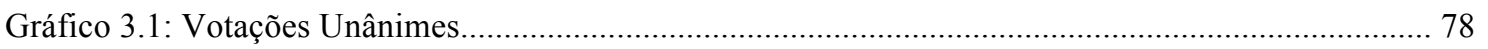




\section{Sumário}

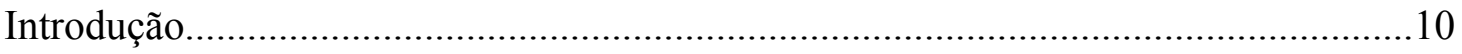

Capítulo 1 - Executivo, legislativo e a produção de leis ...............................................14

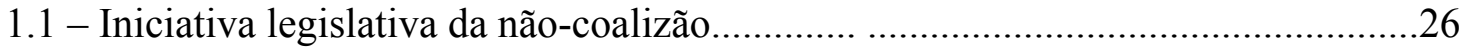

Capítulo 2 - A participação dos membros da não-coalizão na produção legislativa.....38

2.1 - Participação dos membros da não-coalizão na tramitação dos projetos............... 46

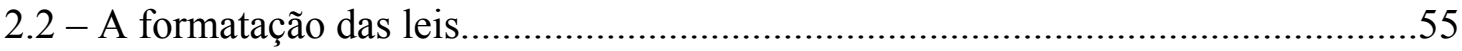

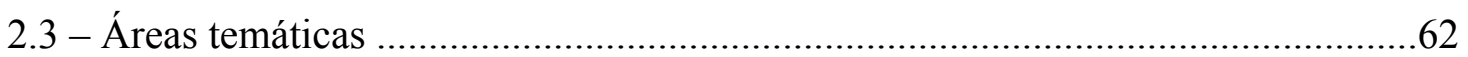

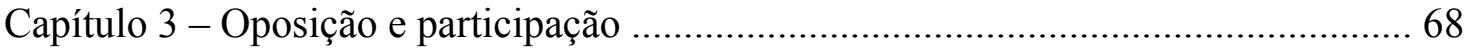

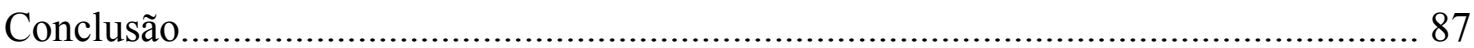

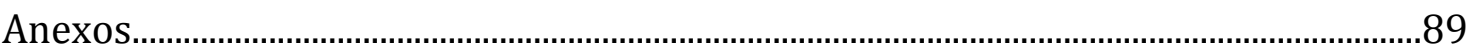

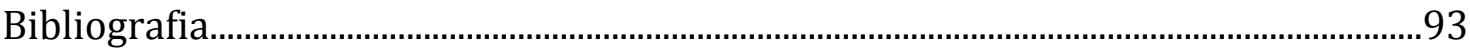




\section{Introdução}

No regime democrático brasileiro, os regimentos internos das casas legislativas requerem no mínimo a maioria simples dos votos para que uma lei seja aprovada. Governos devem então buscar maiorias para governar e é sabido que no período pós 1988, salvo poucas exceções, Presidentes formaram coalizões que contam com a maioria das cadeiras do parlamento, medida suficiente, em teoria, para aprovar sua agenda de governo ${ }^{1}$. Neste contexto, e tendo em vista os altos graus de disciplina partidária observados pela literatura especializada (Figueiredo e Limongi, 1995) não seria estranho esperar que restasse à minoria legislativa, e aos atores que se encontram fora da coalizão de governo, pouca ou nenhuma possibilidade de ter suas propostas aprovadas ou mesmo ter garantida sua participação naquelas instâncias que importam para moldar o processo legislativo. Assim, não seria estranho inferir que aos atores alijados do guarda-chuva do Executivo, caberia esperar a sua vez de ser governo para também participar do jogo democrático de forma cabal, como participante e formulador substantivo do processo político. Essa é uma perspectiva logicamente derivada das regras do processo democrático, mas pouca ou nenhuma atenção tem sido dada ao desempenho dos partidos que não participam da coalizão de governo para que isso possa ser empiricamente comprovado. Sua atuação, quando muito, é vista pelo lado negativo - obstruções e tentativas de veto - não passando de um elemento secundário da análise da atuação da maioria. Seu lado propositivo, seu desempenho efetivo, ainda não mereceram a atenção de nenhum estudo definitivo. Meu objetivo, ainda que sem pretender esgotar a análise, é avançar nesse sentido.

\footnotetext{
${ }^{1}$ Projetos de Lei Ordinária, Projetos Orçamentários e Medidas Provisórias exigem um quorum de Maioria Simples para que sejam aprovados, ou 50\% + 1 dos membros de cada casa legislativa. Nos Projetos de Lei Complementar é necessária a Maioria Absoluta dos votos para que um projeto seja aprovado, ou seja, os votos da maioria dos membros presentes em plenário. No caso dos Projetos de Emenda à Constituição é requerida maioria qualificada de $3 / 5$.
} 
Para tanto, antes de tudo é necessário diferenciar entre minoria e oposição, estabelecendo uma distinção dentro desse bloco de partidos que não fazem parte da coalizão formal de governo. Usualmente se toma como sinônimo não participar da coalizão e ser membro da oposição, mas essa não deve ser tomada como uma associação imediata. Nem todos os partidos que estão fora da coalizão devem ser entendidos como membros da oposição. Alguns podem não ser membros da coalizão, mas se comportar como se fossem, por seu alinhamento às propostas do governo. Há, então, uma importante distinção entre coalizão de governo e coalizão legislativa. E isso se torna bem explícito quando temos em conta a existência de coalizões minoritárias de governo. Pois, se coalizão de governo é minoritária e mesmo assim não há paralisia decisória, como já amplamente demonstrado pela literatura Figueiredo e Limongi $(1998,1999)$ e Santos $(1997,1999)$, tem de haver uma coalizão legislativa superposta e não coincidente com o conjunto de parlamentares aglutinados sob a coalizão formal de governo dando apoio ao governo ${ }^{2}$, sendo "a primeira constituída pelos partidos que recebem pastas ministeriais e apóiam formalmente o governo. [E] a segunda lhe assegura[ndo] votos para aprovar as matérias de seu interesse [do governo]" (Limongi, 2003).

Essa distinção entre os dois tipos de coalizão não se aplicam apenas aos casos de governo minoritário. A diferença é que estes, por definição, só existem quando essas coalizões não são idênticas, sendo o apoio da coalizão legislativa essencial. Mas, de fato, elas não precisam coincidir em nenhum caso. Mesmo quando o governo é majoritário ele pode contar com o apoio de partidos ou deputados que não fazem parte da coalizão, e esse, por vezes, pode ser necessário à aprovação dos projetos. Basta que os membros da coalizão de governos sejam minimamente indisciplinados, ou que haja

\footnotetext{
${ }^{2}$ Freitas (2009) mostra que, de fato, partidos formalmente fora do governo (sem pastas ministeriais) dão apoio sistemático à agenda governista. São os partidos chamados "satélites".
} 
um número elevado de faltas, por exemplo, para haver a necessidade do apoio de outros partidos situados fora da coalizão.

Estabelecer tal fato, no entanto, não implica necessariamente em dizer que maiorias legislativas são formadas caso a caso, como foi posto pelos primeiros estudos sobre o sistema político brasileiro, e que isto tenderia ao que foi cunhado de "paralisia decisória" (Lamounier, 1994) por esta corrente analítica. Ao contrário, significa dizer que existe certa coerência na atuação dos atores dentro do parlamento, que varia de acordo com seu peso. A participação constante dos atores que se situam fora da coalizão de governo denota a existência de uma coalizão legislativa que é maior que o governo que pode se estender até mesmo aos partidos tidos como de oposição -, independente deste compor coalizões majoritárias ou não. E isso pode ser melhor avaliado se levarmos a investigação para além do input inicial dos projetos que são aprovados (sua autoria), passando a computar todas as etapas do processo legislativo. O resultado é fruto do processo, e é no processo que podemos entender como se dá a participação. $\mathrm{O}$ objetivo amplo do trabalho é, assim, avançar nosso entendimento sobre as chances reais que os grupos ou partidos têm de serem ouvidos, de participar do processo de discussão e formatação das leis, componham eles a coalizão e governo ou não, sejam majoritários ou minoritários.

Em termos práticos, a investigação se inicia a partir do exame de como se dá a participação dos parlamentares que não compõem a base governista, seja ela majoritária ou minoritária, e, posteriormente, do estudo das possibilidades que os partidos tidos como de oposição têm de expressar suas preferências (seja avançando projetos de sua autoria, seja tendo suas posições acatadas em projetos de autoria do governo ou de membros de sua base formal) em um arranjo que lhes é desfavorável. 
Os dados que serão apresentados pretendem afirmar que de fato há participação substantiva desses membros ao longo do processo de tramitação das matérias. E mais, que essa participação, no que se refere a ajustes e inputs nas matérias transformadas em lei, se aproxima da proporcionalidade no que se refere ao peso que cada bloco. Também, como se verá no último capítulo, que essa proporcionalidade se reflete na participação dos partidos que estão alijados da coalizão de governo. O que, acredito, sirva para atestar a tese de que o sistema político brasileiro é na prática bastante inclusivo, operando em um grau de consenso razoavelmente alto. $\mathrm{O}$ que se pretende mostrar nessa dissertação é que o Congresso é mais importante do que se pensa, fazendo um contraponto à perspectiva lógica de que a coalizão de governo se bastaria por si só, dominando o processo legislativo - haja a vista que governo costuma formar coalizões majoritárias. 


\section{Capítulo 1}

\section{Executivo, Legislativo e a produção de leis}

Antes de iniciar a argumentação a respeito das condições de atuação do grupo de parlamentares que está fora da coalizão governamental, parece interessante retomar a linha mestra do debate que vem sendo travado no Brasil sobre a governabilidade, que circunscreve o espaço em que se insere a presente pesquisa.

$\mathrm{O}$ debate estabelecido entre aqueles que estudam os efeitos dos arranjos institucionais no sistema político brasileiro se divide em duas vertentes. De forma resumida, pode-se dizer que a primeira delas centra sua atenção nos potenciais elementos desagregadores gerados pelas escolhas institucionais brasileiras - como o presidencialismo, a representação proporcional com lista aberta e o federalismo -, enquanto a segunda corrente destaca o elevado grau de cooperação a que o Legislativo é induzido pela concentração de poderes nas mãos do presidente haja vista a lógica centralizada dos trabalhos legislativos.

Filiados à matriz teórica distributivista (Mayhew, 1974; Jacobson, 1992), os autores da primeira corrente descartam a relevância tanto do sistema partidário, quanto da estrutura institucional interna do Congresso como determinantes nos resultados políticos produzidos no âmbito do Legislativo. O ponto de partida desse modelo supõe que a explicação para produção e organização legislativas se localiza fora do Congresso, a saber, no momento eleitoral. Os supostos problemas advindos do arranjo institucional brasileiro infligiriam ao presidencialismo brasileiro altas penas no que tange à implementação de um governo eficaz na produção de políticas públicas. Faltariam assim incentivos institucionais para contrabalancear a dispersão gerada pelo sistema partidário, gerando assim um impasse na produção de soluções para os problemas vigentes. Nestes termos, a conjugação de fatores como presidencialismo, 
multipartidarismo, federalismo e sistema proporcional de lista aberta seria responsável por um arranjo institucional que tem como produto um Congresso Nacional conservador, indisciplinado, pouco coeso e clientelista, assentado em partidos fracos e incapazes de deter os interesses particulares de seus parlamentares (Mainwaring, 1991; Lamounier, 1994; Sartori, 1996).

Muitos analistas dessa corrente destacam que a lista aberta, impedindo o controle da seleção dos candidatos pelos partidos, acaba por falsear um ideário de princípios comuns aos atores aglutinados sob uma mesma sigla partidária, impossibilitando, pelo mesmo argumento, que os partidos criem raízes na sociedade. Isso porque, a escolha dos parlamentares, feita por essas agremiações, se daria mais em função das potencialidades que o candidato teria em angariar votos, em termos não mais que numéricos, do que de suas posições contíguas ao conteúdo programático do partido.

Nesse contexto, não seria anormal esperar que a indisciplina partidária vigorasse na arena parlamentar, dificultando as negociações dentro e entre as casas legislativas, de modo a afetar a estabilidade da coalizão presidencial e levar o Congresso à chamada paralisia decisória. Esses autores tendem a acreditar na existência de uma disjunção dentro do próprio sistema político, na qual a atuação do Legislativo, forte e autônomo, faz do Poder Executivo um refém dos interesses dos parlamentares. A lógica aqui é confrontacionista, resultando em uma espécie de competição entre os Poderes pelos recursos do Estado, em que de um lado se encontrariam os parlamentares em busca de seus interesses próprios e, do outro, o Poder Executivo.

Esse sistema multiplicaria os pontos de veto, sendo responsável por condenar ao fracasso relevantes temas de interesse nacional (Ames, 2001). E isso se daria em virtude dos poderes legalmente garantidos às minorias pela Constituição, que poderiam, ao fazer uso deles, obstruir a tramitação das propostas de lei contrárias aos seus interesses. 
De acordo com a linha de argumentação exposta, as escolhas institucionais brasileiras inviabilizariam a consolidação da democracia no país, uma vez que o Executivo seria incapaz de constituir as maiorias necessárias à implementação de uma agenda governamental. Na visão de todos esses autores, apenas reformas estruturais profundas, que fortalecessem os partidos políticos no interior das casas legislativas e emancipassem o Executivo do poder desagregador exercido pelo individualismo dos parlamentares, poderiam solucionar a situação de permanente crise de governabilidade a que essa divergência de agendas conduziria. Esse conjunto de teses aponta para a ingovernabilidade do modelo brasileiro, entendida como a extrema dificuldade em se produzir mudanças e decisões, a ver pela propalada dispersão do poder decisório.

O que guia a análise aqui é a ação individual dos atores, não havendo espaço para reflexões mais acuradas acerca da ação de grupos que compõem ou não o governo. Ainda, vale relembrar que estas críticas são exógenas ao próprio contexto que estudam, uma vez que as explicações para os fenômenos internos ao Congresso são dadas a partir de observações externas ao mesmo. Em linhas gerais, esse é o mote da tese da ingovernabilidade pela dispersão de poderes. Nas palavras de Figueiredo e Limongi (1998),

\footnotetext{
"Quer nas explicações centradas na legislação eleitoral, quer naquelas derivadas das características próprias à forma de governo presidencialista, inferências são feitas a partir de uma estrutura de incentivos determinada exogenamente. As estratégias dos parlamentares e presidentes são derivadas e totalmente definidas pelo que se passa no campo eleitoral. As análises encontradas na literatura comparada e aquelas sobre o sistema político nacional param, por assim dizer, às portas da primeira sessão legislativa" (Figueiredo e Limongi, 1998: p. 83).
} 
Nesta mesma linha, mas em sentido oposto, estão as interpretações que vêem na utilização por parte do Executivo dos expressivos poderes legislativos, administrativos e distributivos de que dispõe, a maneira encontrada para excluir os potenciais atores de veto (o Congresso, as unidades federativas e os partidos) do processo decisório e, assim, lidar com os impasses gerados pelo modelo institucional. Aqui, como se vê, também prevalece a perspectiva de que existe uma pauta conflitiva entre os Poderes, e a solução para isso (no limite, a usurpação dos poderes do Congresso pelo Executivo ${ }^{3}$ ) gera uma situação de instabilidade e conflitos permanentes, que tanto não é sustentável no longo prazo quanto põe em risco o próprio sistema representativo. É a linha da ingovernabilidade via concentração do poder decisório, nos termos de Palermo (2000).

Como se vê, essa perspectiva é bastante pessimista quanto às possibilidades de sucesso da atual democracia brasileira. Porém, a simples constatação, após mais de 20 anos de vigência do atual regime, de que o sistema não ruiu vítima de suas escolhas institucionais, mas, pelo contrário, se mostra relativamente bem-sucedido em seus resultados, tanto no que se refere à possibilidade de implementar reformas e manter coalizões operantes quanto na patente ausência de conflito aberto e insolúvel entre os Poderes, parece suficiente para contestar a interpretação aludida. De fato, parece evidente que o modelo institucional adotado pela Constituição de 1988 não inviabiliza a democracia. A dúvida que ainda persiste contempla a maneira pela qual o possível conflito entre os principais atores do processo decisório (Executivo e Legislativo) é resolvido, de modo a garantir que as decisões necessárias sejam tomadas.

A segunda corrente de pensamento traz indicativos importantes nesse sentido. De acordo com os autores que adotam essa perspectiva, regras constitucionais e regimentais vigentes impõem ao Legislativo um comportamento consoante com as

\footnotetext{
${ }^{3}$ Para mais, ver Diniz (1997) e Santos (1999a).
} 
decisões do Executivo em modelo que enfatiza a preponderância deste ator no processo de produção legislativa (Figueiredo e Limongi, 1996 e 1999; Santos, 1999; Ricci, 2003). A análise empírica realizada por Figueiredo e Limongi (1999), fundamentada no estudo sistemático das votações nominais na Câmara dos Deputados entre 1989 e 1998, demonstra que existe uma intensa cooperação do Legislativo com a agenda do Executivo, realidade esta mediada, principalmente, pelos amplos poderes legislativos outorgados ao presidente da República pela Constituição de 1988 e pelos Regimentos Internos das duas casas legislativas (Medida Provisória, urgência constitucional, veto total ou parcial ${ }^{4}$, exclusividade de proposição de projetos de leis orçamentárias ${ }^{5}$ e de administração pública).

Os dados apresentados pelos autores descrevem um Congresso extremamente disciplinado, composto por deputados que seguem as orientações dos líderes de seus partidos, o que torna o resultado das votações bastante previsível. Segundo Figueiredo e Limongi, a concentração dos recursos legislativos na Mesa Diretora e nos líderes partidários também contribui de forma decisiva para a preponderância do Executivo no processo legislativo ${ }^{6}$.

Denotando a força dos partidos políticos no interior do Legislativo, essa centralização do poder decisório nas mãos dos líderes partidários minimizaria os incentivos ao comportamento particularista dos parlamentares, tornando assim possível,

\footnotetext{
${ }^{4} \mathrm{O}$ Legislativo possui poderes constitucionais para derrubar o veto presidencial, medida que, no entanto, precisa ser sufragada pela maioria absoluta dos parlamentares reunidos em sessão conjunta do Congresso Nacional. Shugart e Carey (1992, p. 134) lembram que "embora seja tecnicamente um poder negativo, o veto parcial permite ao presidente dissecar a legislação e criar pacotes finais que são mais aceitáveis ao Executivo [...] como resultado, o poder presidencial se torna mais flexível e mais potente do que seria somente com o veto total".

${ }^{5} \mathrm{O}$ Congresso dispõe do direito de propor emendas às propostas de lei orçamentária apresentadas pelo Executivo, mas apenas nos casos em que essas emendas, além de respeitarem a Lei de Responsabilidade Fiscal, não entrarem em conflito como a Lei de Diretrizes Orçamentária (LDO) e com o Plano de Orçamento Plurianual elaborado pelo governo.

${ }^{6}$ Esse domínio do Executivo, deve-se notar, não é garantido, já que mesmo as Medidas Provisórias, instrumento legal considerado pela literatura como essencial na preponderância do Executivo, devem ser aprovadas por uma maioria dos congressistas para serem efetivadas em lei.
} 
mesmo em um regime presidencialista com eleições proporcionais por lista aberta, o estabelecimento de uma coalizão de governo estável, que daria respaldo a uma atuação dominante do Executivo, então levando a cabo a sua agenda. Aqui, como mostra Palermo (2000), a tese é a da governabilidade via concentração do poder decisório.

As duas linhas argumentativas apresentadas, que avançam interpretações opostas no que se refere às possibilidades de sucesso do modelo institucional brasileiro, ainda se aproximam ao suporem uma elementar separação entre as agendas dos dois poderes. Quando se trata de agenda, o debate varia entre a existência de uma agenda dual, de soma-zero, onde a vitória de um ator implica na derrota do outro; e a noção de prevalência de uma agenda do Executivo, institucionalmente induzida e que, apesar de não ser contrária à vontade da maioria (Figueiredo e Limongi, 1998, 1999), é sancionada quase que mecanicamente pelo Legislativo.

Todavia, é tempo de se questionar o real sentido de se tratar Executivo e Legislativo como entidades separadas, portadoras de agendas independentes. Isto porque muito da avaliação que se identifica com a noção de agenda do Executivo é advinda do conceito de poder de agenda definido nos trabalhos de Figueiredo e Limongi (1998, 1999). Ao tratarem das prerrogativas de poder acumuladas nas mãos da Mesa Diretora e das lideranças partidárias, assim como dos poderes legislativos do Poder Executivo, os autores afirmam a capacidade deste em determinar quais as propostas o Congresso Nacional deve considerar e, mais importante, quando as matérias serão analisadas. Contudo, os mesmos pesquisadores refinaram o foco analítico em artigo mais recente, delimitando com maior precisão sua leitura de "agenda do Executivo", distinta do "poder de agenda do Executivo". Na visão de Figueiredo e Limongi, o termo "agenda do Executivo" deve ser usado muito mais como um recurso analítico do que como um dado objetivo. Tal agenda, ou seja, "o conjunto de propostas, com razoável 
grau de integração, compondo algo muito próximo de um programa de governo", só poderia ser entendida assim se derivasse de uma "formulação exterior e prévia à sua submissão ao Poder Legislativo" (Figueiredo e Limongi, 2009, p.78) - conjuntura contestada pelos próprios especialistas.

Uma agenda do Executivo formulada nestes termos - exterior e anterior suporia necessariamente uma outra agenda que à ela se contrapusesse, "formada autonomamente no interior do Poder Legislativo, que responderia aos interesses eleitorais dos parlamentares" (idem). Ou seja, haveria uma agenda do Legislativo disputando por recursos escassos com à do Executivo, dado que somente uma delas seria implementada, em detrimento da outra. Esta, por definição, é a tese da agenda dual. Endossá-la perpassa supor que a mera existência de uma agenda do Executivo implicaria a efetivação das características negativas atribuídas por parte da literatura ao arcabouço institucional brasileiro, pois essa tese pensa a agenda dual como necessariamente gerada pela agenda do Executivo. Contudo, Figueiredo e Limongi (2009) descartam a tese da agenda dual (e, por conseqüência, também a da agenda do Executivo) com base em dados sobre aprovação e execução orçamentária, buscando demonstrar, através da distribuição e controle do gasto pela maioria legislativa, que Executivo e Legislativo "se interpenetram e se fundem" na execução da agenda (Figueiredo e Limongi, 2009, p. 100).

Deve-se dizer que essa concepção sobre o processo legislativo, esboçada em Figueiredo e Limongi (2009) e aqui avançada, não é nova. Ao contrário, ela é amparada pela ampla literatura debruçada ao exame do declínio dos Parlamentos europeus em sistemas parlamentaristas multipartidários (Huber, 1996; Thies, 2001; Heller, 2001; Huber e McCarty, 2001; Martin, 2004) - em um arcabouço, portanto, que não percebe Executivo e Legislativo como instituições separadas. Estudos de caso realizados na 
França (Kerrouche, 2006), Alemanha e Holanda (Martin e Vanberg, 2004, 2005) mostram, em diferentes medidas, o impacto substantivo (proposição de projetos e/ou alterações nos projetos do Executivo) que a ação do Legislativo tem sobre as políticas aprovadas, apontando para a existência de certa medida de compartilhamento da agenda entre Executivo e Legislativo.

Neste sentido, Freitas (2010) buscou na análise da formulação das leis aprovadas e iniciadas pelo Executivo no pós-Constituinte (1988-2009) a origem da agenda do governo. Para o autor, "os dados apresentados indicam que a agenda é substantivamente compartilhada entre os Poderes e que a maioria legislativa exerce forte participação nas propostas, seja ela parte da base formal do governo ou não" (Freitas, 2010, p. 96). O trabalho avança a idéia de que a agenda de governo aprovada pelo Executivo é composta no interior da maioria legislativa, contando com a participação direta do Legislativo (Figueiredo e Limongi, 2009). Mais do que isto, mostra como as instâncias internas do Congresso, como as Comissões Permanentes, privilegiam diretamente a maioria e abrem espaço para ajustes nas propostas de lei visando sanar as divergências existentes em torno das políticas.

Podemos também avançar essas análises ao fazer um contraponto com a perspectiva teórica, e aqui o modelo proposto por Lijphart nos será útil. Em Modelos de Democracia (2003), Arent Lijphart propõem um esquema analítico, já amplamente difundido, que permite classificar as democracias contemporâneas em dois tipos ideais de modelo político; majoritário e o consensual. Trata-se a princípio de elencar uma série regras institucionais que, separadas em dois eixos - Executivo/partidos e Federal /unitário - nos ajudariam a enquadrar as democracias modernas nos dois tipos normativos de governo. No modelo majoritário, (também chamado de Westminster) haveria a preponderância das regras institucionais favoráveis a prevalência das vontades 
majoritárias no processo político governamental, enquanto no modelo consensual (também chamado de consociativo) seriam marcantes a presença de regras favoráveis à expressão das diversas parcelas de uma sociedade e/ou sistema político. No que diz respeito à essência desses modelos, o autor traça as seguintes palavras:

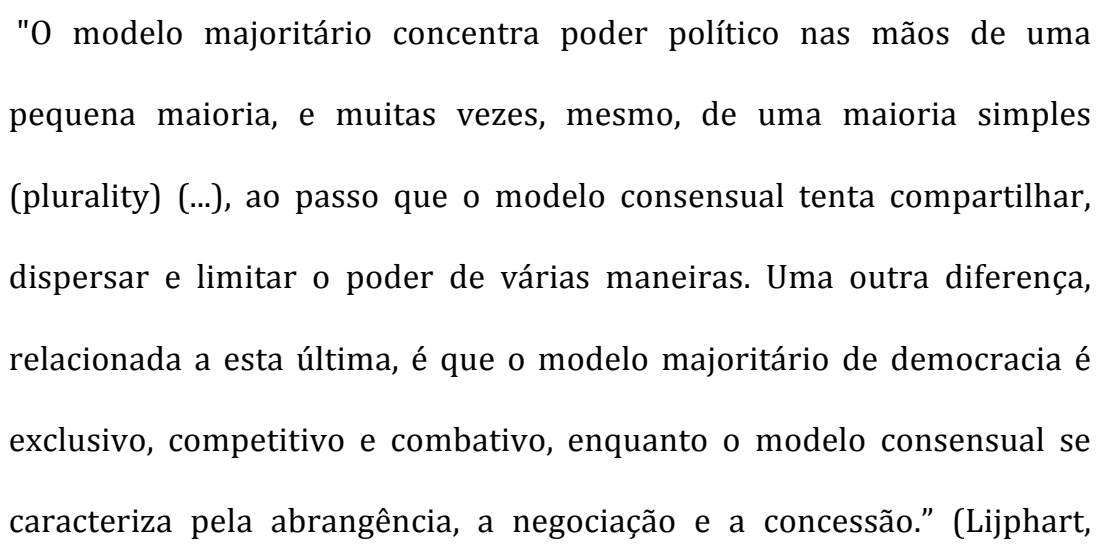
2003, p. 18)

A tabela abaixo, extraída de Anastásia e Nunes (2006), sintetiza o esquema analítico de Lijphart :

Tabela 1.1: Esquema analítico de Lijphart

\begin{tabular}{|c|c|c|c|c|c|c|c|c|c|c|}
\hline & \multicolumn{5}{|c|}{ Executivo / Partidos } & \multicolumn{5}{|c|}{ Federalismo / Unitarismo } \\
\hline & $\begin{array}{l}\text { Poder } \\
\text { Executivo }\end{array}$ & $\begin{array}{c}\text { Relaçäo entre } \\
\text { os Poderes }\end{array}$ & $\begin{array}{c}\text { Sistema } \\
\text { Partidário } \\
\end{array}$ & $\begin{array}{l}\text { Sistema } \\
\text { Eleitoral }\end{array}$ & $\begin{array}{c}\text { Grupos de } \\
\text { Interesse }\end{array}$ & $\begin{array}{c}\text { Poder } \\
\text { Legislativo }\end{array}$ & $\begin{array}{c}\text { Federalismo/ } \\
\text { Unitarismo }\end{array}$ & $\begin{array}{c}\text { Emenda } \\
\text { Const./ } \\
\text { Veto } \\
\end{array}$ & $\begin{array}{l}\text { Revisão } \\
\text { Constit. }\end{array}$ & $\begin{array}{l}\text { Banco } \\
\text { Central }\end{array}$ \\
\hline Consensual & $\begin{array}{l}\text { Grandes } \\
\text { Coalizōes }\end{array}$ & $\begin{array}{l}\text { Separaçãocom } \\
\text { checks and } \\
\text { balances }\end{array}$ & $\begin{array}{c}\text { Multi- } \\
\text { partidário }\end{array}$ & $\begin{array}{c}\text { Representação } \\
\text { Proporcional }\end{array}$ & Corporativistas & $\begin{array}{l}\text { Bicameral } \\
\text { Simétrico }\end{array}$ & Federalismo & $\begin{array}{l}\text { Maioria } \\
\text { Qualific. }\end{array}$ & Independ & Independ \\
\hline Majoritário & $\begin{array}{l}\text { Governo } \\
\text { unipartidário } \\
\text { com maioria } \\
\text { estrita }\end{array}$ & $\begin{array}{c}\text { Fusão e } \\
\text { predomínio } \\
\text { do Executivo }\end{array}$ & Bipartidário & Majoritário & Pluralistas & $\begin{array}{l}\text { Bicameral } \\
\text { Assimétrico } \\
\text { (ou } \\
\text { Unicameral) }\end{array}$ & Unitarismo & $\begin{array}{l}\text { Maioria } \\
\text { Absoluta }\end{array}$ & Depend & Depend \\
\hline
\end{tabular}

Como podemos notar, o sistema político institucional brasileiro computa quase todas as características do modelo consensual. Um Poder Executivo que conta com amplas coalizões multipartidárias de governo, na qual há separação dos poderes; federalismo; um Poder Legislativo bicameral simétrico; um sistema eleitoral de representação proporcional, com direito a revisão Constitucional por parte do Supremo 
Tribunal Federal, e a necessidade de maiorias qualificadas para a modificação da Carta Magna. Por fim, no que diz respeito aos grupos de interesse, os pluralistas trabalham em uma chave confrontacionista mais afeita ao lado majoritário, segundo Amorim (2009) privilegiando o embate entre diferentes correntes, de forma, em tese, mais restritiva ao consensualismo que poderia ser alcançado por um número menor de atores, os corporativistas.

No entanto, tudo somado, essas características fazem formalmente do nosso modelo um sistema consensual bastante pronunciado como tem sido atestado pelos especialistas que trataram do tema (Abranches, 88; Amorim, 2009; Anastásia et al., 2007; Anastásia et al., 2004; Anastásia e Nunes, 2006; Lamounier, 1992; 2003; Santos, 1987). Se anteriormente isso foi motivo para preocupação com a capacidade do modelo em garantir de fato as maiorias necessárias para que governo brasileiro conseguisse governar, as atenções hoje se voltam para o custo que dito modelo pode trazer à representação e à a atividade parlamentar. Dito de outro modo, existe "receio que o preço pago por nossa 'governabilidade' nos moldes atuais seja a concentração de competência legislativa na figura do Presidente da República - a um ponto que roça o aviltamento da atividade parlamentar, e arrisca desmoralizar o Congresso Nacional aos olhos da opinião pública” (Reis, 2007, p. 6).

O fator que gera insatisfações é que, se por um lado o sistema é capaz de produzir maiorias e decidir rotineiramente, evitando paralisias decisórias, como nos mostram convincentemente Figueiredo e Limongi, essa seria uma dimensão necessária, porém insuficiente para avaliar um sistema político que se queira democrático. Ou seja, a critica aqui não se volta para o imperativo de natureza decisionística, centrado na viabilização de decisões e do exercício do poder pela autoridade constituída pela maioria que a legitime - o princípio majoritarista, apontado por Lijphart. Mas sim pela 
ausência da garantia de que o princípio consensualista de fato tome corpo dentro do sistema de governo brasileiro. Trata-se, então, não somente de avaliar a capacidade do sistema político de governar, mas também de "fazê-lo sem prejuízo grave para o exercício do veto por minorias relevantes em pontos cruciais do processo - que force a eventual maioria a ouvi-las" (idem). Em linhas amplas, requere-se um certo equilíbrio entre as características centralizadoras da arena parlamentar e as características descentralizadoras da arena eleitoral.

Como exemplo disso, Fabiano Santos (2006), tem insistido na relevância de se reverem os instrumentos normativos que regulam a relação entre os poderes. $\mathrm{O}$ foco de sua preocupação é a concertação de um sistema que seja mais equânime, ora desconcentrando as prerrogativas centradas nas mãos do Poder Executivo, de forma a equalizar os instrumentos institucionais de cada um dos poderes. Mas será que se olharmos para o modo como se dá a participação dos atores "mais vulneráveis" - ou seja, com menor número de instrumentos institucionais ao seu dispor - encontraremos indícios de que sua participação é relegada a um segundo plano, por ser concretizada o dia em que se tornem governo? Participam menos que os atores governamentais, que soem compor a maioria? Veremos.

Se no caminho percorrido até aqui pudemos notar que a literatura especializada tem se focado na questão da operacionalidade do sistema, é digno de nota que se houve avanço além do eixo decisionísta, ele tem direcionado suas atenções mais para a análise de como opera a maioria legislativa que garante a governabilidade do sistema, sem se ater a que atores de fato compõem essa maioria, e mesmo como os que estão alijados dela participam do processo de toma de decisão. Estudos recentes (Figueiredo e Limongi, 2009; Freitas, 2010) mostram que a maioria legislativa é responsável por mover essa operacionalidade, mas não dizem nada a respeito da participação daqueles 
atores que esperaríamos que tivessem poucas chances de participar do processo - dados os incentivos que compõem as coalizões majoritáias de governo e mesmo a preponderância destas ao longo dos ultimo 20 anos.

Que o sistema funcione ninguém duvida, mas a que custo para a representação dos partidos e das minorias?

Seguindo no percalço das respostas para essas perguntas, pretende-se questionar, a partir de agora, se o espaço que encontra-se aberto à participação da maioria também está aberto aos parlamentares que não fazem parte do governo, tanto em coalizões governamentais majoritárias quanto minoritárias. Queremos entender em que grau se dá a participação desses atores na prática, uma vez que sabemos que institucionalmente eles têm garantida sua participação 


\section{1 - Iniciativa legislativa da não-coalizão}

Ao recapitularmos alguns dos achados da corrente da governabilidade com concentração de poder, podemos notar que a centralização do poder decisório nas mãos dos líderes partidários e as altas taxas de disciplina dos principais partidos brasileiros não apenas minimizariam os incentivos ao comportamento particularista dos parlamentares, tornando possível o estabelecimento de uma coalizão de governo estável, como dariam respaldo para uma atuação dominante do Executivo. Os dados abaixo, apresentados por Figueiredo e Limongi (1999) e aqui atualizados até o ano de 2010, ao fim do segundo mandato de Lula, demonstram a validade dessa proposição:

Tabela 1.2: Leis aprovadas por órgão propositor

\begin{tabular}{|c|c|c|c|c|}
\hline Presidente & Executivo & Legislativo & Judiciário & Total \\
\hline Sarney* & $266(69,1 \%)$ & $91(23,6 \%)$ & $28(7,3 \%)$ & $385(100 \%)$ \\
\hline Collor & $423(69,6 \%)$ & $139(22,9 \%)$ & $46(7,6 \%)$ & $608(100 \%)$ \\
\hline Itamar & $399(86,4 \%)$ & $44(9,5 \%)$ & $19(4,1 \%)$ & $462(100 \%)$ \\
\hline FHC I & $666(79,7 \%)$ & $157(18,8 \%)$ & $13(1,6 \%)$ & $836(100 \%)$ \\
\hline FHC II & $706(74,1 \%)$ & $227(23,8 \%)$ & $20(2,1 \%)$ & $953(100 \%)$ \\
\hline Lula I & $626(72,7 \%)$ & $213(24,7 \%)$ & $22(2,6 \%)$ & $861(100 \%)$ \\
\hline Lula II** & $407(80,6 \%)$ & $78(15,4 \%)$ & $20(3,9 \%)$ & $505(100 \%)$ \\
\hline Total & $3462(75,1 \%)$ & $977(21,2 \%)$ & $169(3,6 \%)$ & $4608(100 \%)$ \\
\hline
\end{tabular}

Fonte: Banco de Dados Legislativos - Cebrap

* A partir de 05 de outubro de 1988.

**Até 31 de dezembro de 2010.

Como pode se observar, o Executivo detêm amplo domínio sobre a produção legal brasileira desde a promulgação da Constituição de 1988. Isso pode ser notado também nos altos índices de sucesso e dominância expressos na tabela abaixo: 
Tabela 1.3: Taxa de sucesso e dominância do Executivo

\begin{tabular}{|c|c|c|}
\hline Governo & Sucesso (\%) & Dominância (\%) \\
\hline Sarney* & 73,6 & 76,1 \\
\hline Collor & 64,4 & 76,1 \\
\hline Itamar & 72,6 & 91,2 \\
\hline FHC I & 80,9 & 83,3 \\
\hline FHC II & 74,6 & 76,1 \\
\hline Lula I & 79,1 & 75 \\
\hline LulalI** & 68,1 & 83 \\
\hline Média & 73,3 & 80,1 \\
\hline
\end{tabular}

Fonte: Banco de Dados Legislativos Cebrap

*A partir de 05 de outubro de 1988.

**Até 31 de dezembro de 2010.

Uma interpretação simplificada desse contexto levaria à idéia de que o espaço de participação do Legislativo como um todo é restrito. Porém, um olhar mais acurado sobre a produção legal brasileira evidencia que a dominância do Executivo é insuflada pela aprovação de propostas de lei em que Executivo tem prerrogativa privativa na proposição, como se vê na tabela a seguir. 
Tabela 1.4 - Produção legal do Executivo, por tipo de lei e por governo

\begin{tabular}{|l|c|c|c|c|c|c|}
\hline Presidente & $\begin{array}{c}\text { Medidas } \\
\text { Provisórias }\end{array}$ & $\begin{array}{c}\text { Projetos } \\
\text { de Lei } \\
\text { Ordinária }\end{array}$ & $\begin{array}{c}\text { Projetos de } \\
\text { Lei } \\
\text { Orçamentária }\end{array}$ & $\begin{array}{c}\text { Projetos de Lei } \\
\text { Complementar }\end{array}$ & $\begin{array}{c}\text { Propostas } \\
\text { de Emenda } \\
\text { à } \\
\text { Constituição }\end{array}$ & Total \\
\hline Sarney* & $\begin{array}{c}107 \\
(44,2 \%)\end{array}$ & $\begin{array}{c}33 \\
(13,6 \%)\end{array}$ & $102(42,1 \%)$ & - & - & $\begin{array}{c}242 \\
(100 \%)\end{array}$ \\
\hline Collor & $66(19,2 \%)$ & $93(27 \%)$ & $181(52,6 \%)$ & $4(1,2 \%)$ & - & $\begin{array}{c}344 \\
(100 \%)\end{array}$ \\
\hline Itamar & $119(32 \%)$ & $\begin{array}{c}58 \\
(15,6 \%)\end{array}$ & $192(51,6 \%)$ & $3(0,8 \%)$ & - & $\begin{array}{c}372 \\
(100 \%)\end{array}$ \\
\hline FHCI & $\begin{array}{c}143 \\
(22,7 \%)\end{array}$ & $\begin{array}{c}89 \\
(14,1 \%)\end{array}$ & $384(61 \%)$ & $2(0,3 \%)$ & $11(1,7 \%)$ & $\begin{array}{c}629 \\
(100 \%)\end{array}$ \\
\hline FHC II & $\begin{array}{c}172 \\
(25,2 \%)\end{array}$ & $\begin{array}{c}78 \\
(11,4 \%)\end{array}$ & $418(61,2 \%)$ & $11(1,6 \%)$ & $4(0,6 \%)$ & $\begin{array}{c}683 \\
(100 \%)\end{array}$ \\
\hline Lula I & $\begin{array}{c}216 \\
(36,7 \%)\end{array}$ & $\begin{array}{c}78 \\
(13,2 \%)\end{array}$ & $292(49,6 \%)$ & - & $3(0,5 \%)$ & $\begin{array}{c}589 \\
(100 \%)\end{array}$ \\
\hline Lula II & $\begin{array}{c}134 \\
(31,1 \%)\end{array}$ & $\begin{array}{c}60 \\
(13,9 \%)\end{array}$ & $234(54,3 \%)$ & $1(0,2 \%)$ & $2(0,5 \%)$ & $\begin{array}{c}431 \\
(100 \%)\end{array}$ \\
\hline Total & $\begin{array}{c}957 \\
(100 \%)\end{array}$ & $\begin{array}{c}489 \\
(100 \%)\end{array}$ & $1803(100 \%)$ & $21(100 \%)$ & $20(100 \%)$ & $\begin{array}{c}3270 \\
(100 \%)\end{array}$ \\
\hline
\end{tabular}

Fonte: Banco de Dados Legislativos Cebrap

*A partir de 05 de outubro de 1988.

**Até 31 de dezembro de 2010.

A exclusividade na apresentação de Projetos de Lei Orçamentária, por exemplo, superestima o poder de iniciativa legislativa do Executivo, pois muitos desses projetos lidam com a administração miúda do governo. Somente a partir do estudo desse tipo de legislação específica, e dá análise detida dos recursos envolvidos nestas leis, seria possível afirmar se elas são de fato importantes ou não ${ }^{7}$. Os Projetos de Lei Orçamentária devem, portanto, ficar de fora da análise.

\footnotetext{
${ }^{7}$ No mais das vezes estes projetos têm a função de fazer valer os acordos que tomaram lugar quando da aprovação da LOA (Leis orçamentárias anuais), que por sua vez é balizada pela LDO (Lei de Diretrizes orçamentárias) e PPA(Plano Plurianual), balizados pelas decisões tomadas dentro do Congresso. Logo, pouca ou nenhuma participação é esperada nesse tipo de legislação de prerrogativa exclusiva do Poder Executivo. De forma mais ampla, a maior parte de tudo que editado por esse tipo de legislação não passam de verbas já empenhadas para o custeio da máquina pública. Colocamos dessa forma porque, uma pequena parte desse montante é destinado para valores que podem ser remanejados, os chamados investimentos.
} 
Do mesmo modo, não seria coerente somar na análise os Projetos de Emenda à Constituição (PEC) em função de seu regime de tramitação ser de caráter muito específico e díspar dos demais. No que interessa diretamente a esse estudo, o quorum estabelecido para que esse tipo de legislação seja aprovada ultrapassa os 50\% +1 que regem todos demais tipos, já que exige a anuência de $3 / 5$ dos presentes para que seja aprovada. As maiorias que têm de ser formadas aqui não são as mesmas que as exigidas na produção da legislação corrente. Da mesma forma, as regras também são diferentes, e não parecem exercer a mesma influência sobre os atores se comparadas com os outros tipos de legislação. Isso porque, seu rito de tramitação ${ }^{8}$, ao forçar que se alcance um consenso entre ambas as casas legislativas, provoca incentivos extras à participação dos atores. Um estudo, ou capítulo à parte para a investigação de como a não-coalizão participa desse tipo de legislação poderia ser relevante nesse estudo, não fosse o fato de que pouquíssimas leis desse tipo terem sido aprovadas desde a promulgação da Constituição para cá.

Um outro tipo de legislação que deve, e será excluída da análise, são as leis de homenagem $^{9}$, uma vez que não constituem objeto de disputa e tampouco moldam as políticas de Estado. Abarcar o estudo dessas leis aqui enviesaria o entendimento de como atua a não-coalizão, na medida em que aumentaria razoavelmente a sua participação. E, por fim, não parece coerente somar à análise os projetos de lei que, tendo sido apresentados, não foram aprovados. A justificativa é simples: não está sob questão o sucesso legislativo, mas sim a participação desses atores no processo de

\footnotetext{
${ }^{8}$ Segundo o artigo 60, § 2, da Constituição Federal que define as regras de como deve se dar a tramitação dos projetos de Emenda à Constituição "A proposta será discutida e votada em cada Casa do Congresso Nacional, em dois turnos, considerando-se aprovada se obtiver, em ambos, três quintos dos votos dos respectivos membros.". Resumindo: qualquer alteração, modificação empreendida pelo Senado ou Câmara no projeto, tem de ter a anuência de $3 / 5$ da outra casa para que o projeto seja aprovado. Logo o mesmo pode tramitar por ambas as casa indefinidamente, diferente do que acontece com os outros tipos de projetos de lei.

${ }_{9}^{9}$ Também chamados de "simbólicos", segundo a classificação de Ricci (2003), estes projetos tratam de dar nomes a ruas, avenidas, escolas etc.
} 
feitura das leis. Ademais, os legisladores, via o órgão de assessoria parlamentar das casas legislativas, têm custo praticamente nulo para apresentar um projeto de $1 \mathrm{ei}^{10}$. Por outro lado, somente olhando para a legislação que foi aprovada é possível constatar o modo como a não-coalizão participa efetiva e positivamente do processo. Afinal, apenas o resultado final - a transformação das propostas em norma jurídica - é capaz de ratificar cada uma das etapas anteriores do processo legislativo. Além disso, vale frisar que, mesmo sendo do interesse do parlamentar aprovar leis - se tivermos em conta que isto projeta sua atividade e respalda seu próprio trabalho enquanto legislador -, muitas vezes o legislador pode propor uma lei sem ter a intenção real de que esta seja aprovada. Neste caso, a iniciativa serviria somente para justificar o trabalho do representante perante seus próprios eleitores. Daí a necessidade de se focar apenas os projetos transformados em norma jurídica - único recorte capaz de indicar o sucesso real do empenho por parte dos parlamentares e, por extensão, permitir o acompanhamento das reais possibilidades de participação da não-coalizão na atividade legislativa.

Isto posto, vale sinalizar que o recorte analítico aqui discutido privilegiou os governos que tomaram lugar no período que vai da promulgação da Constituição de 1988 até o final de 2010. A justificativa para tal é que a partir da análise desse período podemos verificar não só os espaços abertos à participação da não-coalizão nos governos majoritários e minoritários, como também compreender em que medida nosso arcabouço institucional molda essas relações. Isso porque, dentro do período escolhido, verificam-se tipos diversos de composição de governo. Há governos minoritários e governos majoritários no início, meio e fim das legislaturas e ainda partidos rivais

\footnotetext{
${ }^{10} \mathrm{Na}$ maior parte dos casos, são os assessores parlamentares que redigem as propostas de lei de interesse dos parlamentares. Geralmente os parlamentares pedem as estes que redijam dois pareceres distintos sobre o tema em questão. Feito isso, o parlamentar analisa os pareceres e elege um deles para que o assessor redija um projeto de lei. Não cabe aqui discutir em que medida o projeto é de autoria do parlamentar ou não. No entanto esse processo é guiado sempre pelo deputado ou senador, que conta com $\mathrm{o}$ assessor para fundamentar juridicamente aquela proposta que acredita que deva se tornar lei.
} 
(PSDB e PT) intercalando-se nas coalizões de governo e fora delas. Isso permite agregar os dados sem criar grandes distorções nas médias obtidas, evitando assim enviesar o estudo da atuação da não-coalizão, seja ela numericamente majoritária ou não.

Seguindo os critérios de Figueiredo (2007), o período selecionado conta com 19 coalizões de governo, sendo seis (6) Minoritárias (Collor 1, 2, 3 e 4, FHC II 2, Lula I 1) e as demais Majoritárias (ver Anexo 1).

Para proceder à análise, separamos os grupos de parlamentares em dois blocos, em função de suas respectivas filiações a partidos que compuseram a coalizão de governo ou dela não tomaram parte. Isso porque os partidos que compõem a base de apoio do governo acabam por compartilhar com o mesmo de suas prerrogativas. No presidencialismo de coalizão brasileiro, o Executivo, na figura do governo, compartilha com sua base de apoio uma parcela dos cargos de governo e Ministérios (Figueiredo e Limongi, 2009; Figueiredo, 2008; Amorim Neto, 2006). Basta lembrar que além dos Projetos de Lei Orçamentária, o Executivo conta ainda com exclusividade na proposição de projetos que envolvam matérias lidam com o manejo da administração pública ${ }^{11}$. Em tal medida, não só a distribuição dos cargos da administração pública e nos Ministérios conta como um reforço para os partidos que participam da coalizão de governo, mas também os instrumentos legais de uso exclusivo da presidência (como as medidas provisórias) e as matérias de iniciativa privativa que, uma vez formatada pela agenda

\footnotetext{
${ }^{11}$ Como fixado pelo Artigo 61, $\S 1^{\circ}$ da Constituição Federal , "São de iniciativa privativa do Presidente da República as leis que: I - fixem ou modifiquem os efetivos das Forças Armadas; II - disponham sobre: a) criação de cargos, funções ou empregos públicos na administração direta e autárquica ou aumento de sua remuneração; b) organização administrativa e judiciária, matéria tributária e orçamentária, serviços públicos e pessoal da administração dos Territórios; c) servidores públicos da União e Territórios, seu regime jurídico, provimento de cargos, estabilidade e aposentadoria; d) organização do Ministério Público e da Defensoria Pública da União, bem como normas gerais para a organização do Ministério Público e da Defensoria Pública dos Estados, do Distrito Federal e dos Territórios; e ) criação, estruturação e atribuições dos Ministérios e órgãos da administração pública; f) militares das Forças Armadas, seu regime jurídico, provimento de cargos, promoções, estabilidade, remuneração, reforma e transferência para a reserva."
} 
desses partidos, dá aos parlamentares da coalizão governista artifícios extras para legislar (Figueiredo e Limongi, 2009).

Para fins de contagem, e como modo de diferenciar os grupos, levaremos em conta se os parlamentares estão filiados ou não a partidos que detém alguma pasta ministerial, segundo o critério de classificação feito por Figueiredo (2007). Dessa forma, pode-se medir o quanto ser ou não governo influi nas chances de participação dos grupos. Desse modo, denominarei "governos majoritários" aquelas coalizões de governo que contaram com partidos cujo número de membros somados é superior à metade das cadeiras de cada Casa, seja na Câmara ou no Senado - já que as maiorias em ambas as Casas são relativamente estáveis e coincidem no tempo, não existindo casos em que a coalizão governamental é majoritária na Câmara e minoritária no Senado, ou vice-versa (ver Anexo 1). Por extensão do raciocínio, o inverso disso passa a ser pensado como "governos minoritários". Logo, nos governos majoritários a não-coalizão é numericamente inferior à coalizão, enquanto nos governos minoritários ela é numericamente superior. Assim conseguiremos controlar o peso numérico dos grupos e ver que relevância eles têm no processo legislativo.

Procedida à caracterização dos grupos, agruparei toda a produção legislativa que se deu sob os governos majoritários e minoritários, separando a autoria dos projetos de lei entre parlamentares que faziam ou não parte das legendas componentes da coalizão. Já para averiguar a participação deles ao longo da formulação das leis, tomamos por base a data em que os pareceres dos relatores foram aprovados, assim como as datas em que as modificações empreendidas nos projetos de lei foram aprovadas. A opção por agregar leis aprovadas por ambos os poderes parte da opção de testar em que medida os parlamentares da não-coalizão de fato participam do processo de proposição e formatação das políticas que são aprovadas. 
Em um primeiro momento - foco desse capítulo -, o escopo se voltará para a autoria das leis apenas. Quando, porém, a observação se concentrar sobre o modo como se dá a participação intra-muros, isto é, ao longo da tramitação das matérias que vêm a se tornar lei, as matérias serão divididas entre a) aquelas que são de iniciativa privativa do presidente, b)aquelas que são de iniciativa conjunta dos poderes, e, finalmente, c) aquelas de autoria da não-coalizão.

Para tal, agregamos em nossa análise tantos os projetos cuja proposição é de iniciativa compartilhada entre os Poderes tanto quanto os de iniciativa exclusiva do Executivo.

Isto posto, é hora de checar se o espaço para a participação da não-coalizão seria escasso, dado o critério majoritário, as altas taxas de disciplina partidária e os artifícios institucionais da qual o Poder Executivo dispõe. Na tabela abaixo temos uma panorama geral da autoria de tudo que foi aprovado no período ${ }^{12}$.

Tabela 1.5: Autoria das leis aprovadas, por tipo de governo

\begin{tabular}{|c|c|c|c|}
\hline & Governos Majoritários & Governos Minoritários & Total \\
\hline Coalizão & $1592(89,4 \%)$ & $480(78,8 \%)$ & $2072(86,7,3 \%)$ \\
\hline $\begin{array}{c}\text { Não- } \\
\text { coalizão }\end{array}$ & $188(10,6 \%)$ & $129(21,2 \%)$ & $317(13,3 \%)$ \\
\hline Total & $1780(100 \%)$ & $609(100 \%)$ & $2389(100 \%)$ \\
\hline
\end{tabular}

Fonte: Banco de Dados Legislativos, Cebrap

Os números indicam como ser governo influencia, e muito, nas chances de aprovação de uma proposta. Note-se que, nos governos minoritários, a não-coalizão

\footnotetext{
${ }^{12}$ Das 2703 leis aprovadas, já excluídas daqui as leis orçamentárias do período, 281 delas tratavam eram de projetos de "homenagem", e em 35 delas (sendo duas de "homenagem") seria impossível imputar um autor, já que são leis provenientes ou das Comissões ou de parlamentares sem partido.
} 
aprova mais $(21.2 \%)$ que em governos majoritários (10.6\%). Outro fato a ser destacado é que mesmo quando os governos são majoritários - ou seja, contam com número de votos suficientes para rejeitar qualquer proposta da não-coalizão - ainda sim isso não acontece sempre.

No entanto, esses números podem enganar. Afinal, uma parcela razoável de tudo que é proposto e aprovado é de iniciativa privativa do Presidente da República. Por esse motivo, tomando por base o que dita a Constituição Federal, procedi à análise do conteúdo da ementa das leis aprovadas, separando as leis de iniciativa privativa do chefe do Executivo das demais, uma vez que nem deputados nem senadores podem propor esse tipo de legislação, sendo esses projetos, portanto, sempre da coalizão. Excluindo esses projetos da análise, o número de leis aprovadas cai consideravelmente, passando de 2389 para 1340. Com esse recorte tem-se o número real de projetos que possibilitam a participação equânime dos atores dentro do processo legislativo.

Como podemos notar na tabela abaixo, as porcentagens sofrem interessantes modificações quando se busca comparar as reais oportunidades de participação dos grupos na aprovação de leis de sua autoria.

Tabela 1.6: Autoria de projetos de iniciativa compartilhada, por tipo de governo

\begin{tabular}{|c|c|c|c|}
\hline & Governos Majoritários & Governos Minoritários & Total \\
\hline Coalizão & $792(81,7 \%)$ & $257(69,3 \%)$ & $1049(78,3 \%)$ \\
\hline Não-Coalizão & $177(18,3 \%)$ & $114(30,7 \%)$ & $291(21,7 \%)$ \\
\hline Total & $969(100 \%)$ & $371(100 \%)$ & $1340(100 \%)$ \\
\hline
\end{tabular}

Fonte: Banco de Dados Legislativos, Cebrap. 
Duas conclusões imediatas podem ser tiradas dos dados acima: 1) A nãocoalizão de fato participa do processo, mesmo nos governos majoritários; 2) Participar do governo parece ser de fundamental importância para aprovar leis. Os dados apontam que das 1340 leis aprovadas, 291 (21.7\%) são de autoria da não-coalizão. Nas coalizões de governo minoritário a participação da não-coalizão é sub-representada, mas mesmo assim fica na ordem de $30.7 \%$, mostrando que ser governo é importante para superar a inferioridade numérica, mas não suficiente para evitar que a não-coalizão aprove projetos de sua autoria. Já nos governos majoritários, a minoria aprova $18.3 \%$ das leis uma porcentagem pequena, porém interessante para um grupo que tem de lidar com as altas taxas de disciplinas dos partidos governistas. Mais além, o que esses resultados sugerem é que, primeiramente, independente de ser ou não majoritário o governo conta com poder de agenda, pois em ambos os casos ele se revela sempre responsável por aprovar a maior parte da legislação que é transformada em norma jurídica. O valor expressivo de $78.3 \%$ das autorias de tudo que foi aprovado no período indica que o governo de fato parece dispor de prerrogativas suficientes para ditar o rumo da maior parte dos temas que entraram na pauta de votações. No entanto, é digno de nota que a participação da não-coalizão (minoria em governos majoritários) ainda sim é expressiva se se considera que não conta nem com a superioridade numérica nem com o aparato estatal ao seu dispor. O fato de não poder contar com as prerrogativas do Executivo e ainda assim conseguir contrabalancear a superioridade numérica do governo majoritário faz pensar que a participação do Poder Legislativo é maior do que poderia se supor.

Pensando na tese da agenda dual, o esperado aqui seria que a não-coalizão não aprovasse coisa alguma. Haja visto que isso não acontece, vale o questionamento: o flanco aberto para a participação da minoria é, de fato, pequeno? Uma coisa é deter artifícios tão poderosos (como a edição das Medidas Provisórias) e com isso pautar a 
agenda que vai ser debatida e aprovada, a outra é estar à margem dos dois maiores recursos regimentais (quantidade numérica e prerrogativas exclusivas) para avançar projetos e mesmo assim conseguir fazê-lo. Pelos dados, há mais espaços para consensos e participação na dinâmica parlamentar do que seria de se pressupor.

Tratar de valores relativos e porcentagens do que vem a se tornar lei perpassa por considerar o tamanho relativo dos grupos para entender em que medidas estes se fazem representar dentro do parlamento. Sua capacidade real de participação deve ser ponderada frente ao seu tamanho - 50 deputados alteram mais que 5 . O propósito do gráfico abaixo é contrastar a porcentagem de aprovação nos projetos de iniciativa compartilhada de autoria da não-coalizão com a proporção de cadeiras que a mesma ocupa, a contar pela porcentagem de cadeiras que detinha na data inicial de cada coalizão.

Gráfico 1.1: Iniciativa compartilhada da não-coalizão vs \% cadeiras da não-coalizão

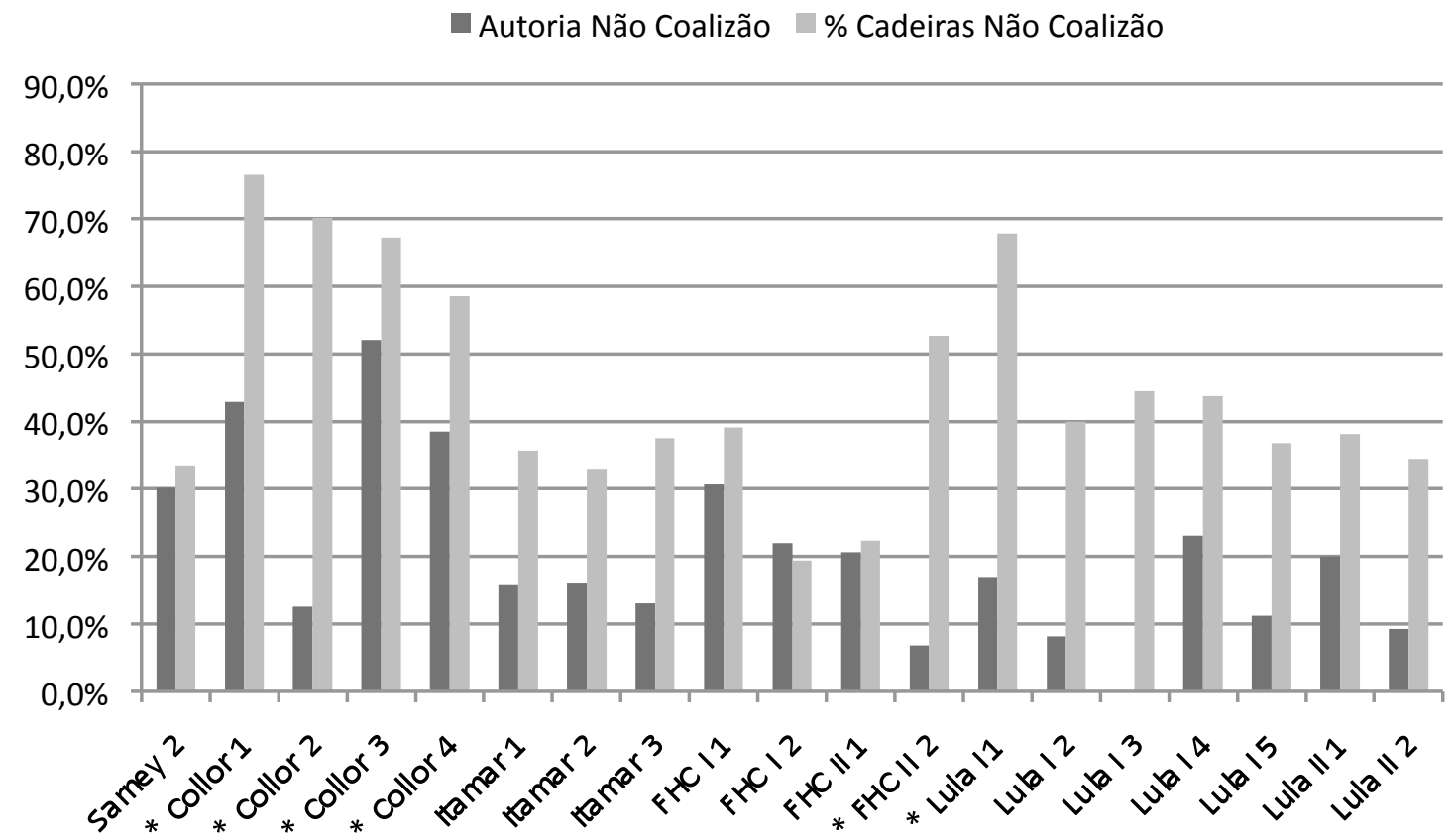

Fonte: Banco de Dados Legislativos, Cebrap 
Novamente os dados confirmam que quem não participa da coalizão de governo tem chances menores de aprovar projetos de sua autoria - são subrepresentados na hora de pautar a agenda. É notável como entre a segunda coalizão de governo do primeiro mandato de Fernando Henrique Cardoso e a primeira coalizão de seu segundo mandato a participação na autoria das leis da não-coalizão é proporcional ao seu tamanho. Em teoria, esses dados nos mostram que a chance de um partido da não-coalizão ditar a agenda dentro dessas coalizões foi igual à possibilidade de partidos da coalizão, guardadas as proporções. A coalizão "Lula I 3" também salta aos olhos, pela falta absoluta de projetos da não-coalizão aprovados no período. Vale lembrar, todavia, que foi nesse período em que estourou o chamado "Mensalão", na qual as atividades do Congresso praticamente pararam. Essa é a coalizão de governo com menor produção de leis do período todo analisado (18 leis aprovadas), e a terceira menor em duração, como pode ser visto no Anexo 1.

No entanto, dizer que a proporção de aprovações está abaixo do esperado tomando por base somente a autoria das leis não é suficiente para definir que participação tem a não-coalizão no processo legislativo. Para fazê-lo, é necessário olhar para dentro do parlamento e averiguar como se dá a participação dos atores para além do processo de apresentação das leis, indo de encontro ao momento onde se dá sua formulação. Eis o foco do próximo capítulo. 


\section{Capítulo 2}

\section{A participação dos membros da não-coalizão na produção legislativa}

No capítulo precedente, vimos que a participação da não-coalizão na aprovação de projetos de sua autoria não pode ser desprezada. Agora é hora de entendermos quais as chances que estão postas para esse grupo em termos de atuação parlamentar positiva. Afinal, trata-se da etapa da feitura das leis mais apropriada ao exame da participação dos parlamentares no processo legislativo, e um sistema político que se queira democrático deve permitir a participação de todos os atores do parlamento. Como já foi destacado, um projeto de lei pode ser completamente desfigurado ao longo da tramitação das matérias. Mesmo que um parlamentar não tenha um projeto seu aprovado, ou que a não-coalizão, como vimos, aprove abaixo da proporção de cadeiras que ocupa, sua participação efetiva e positiva pode se dar, na prática, se o espaço à sua opinião for na prática garantido, nos temas que são regulamentados. Poder influenciar nos rumos do que será aprovado é o que se esperaria de um sistema que aceita divergências e as absorve - é o esperado de um sistema inclusivo e democrático.

Com exceção do trabalho de Freitas (2010), desconheço outro estudo que tenha tratado de observar a instituição parlamentar brasileira através dos mecanismos de uso compartilhado que se encontram abertos à participação dos parlamentares ao longo da tramitação das matérias. Noutras palavras, mecanismos de uso restrito, como a urgência constitucional $^{13}$ que o Executivo pode pedir a projetos de sua iniciativa privativa, têm sido foco de análise dos estudos legislativos desde meados da década de 90 (Figueiredo

\footnotetext{
${ }^{13}$ Cf. art. 64 da Constituição Federal.
} 
e Limongi, 1995), mas o mesmo não pode ser dito de mecanismos como o acesso às relatorias ou a possibilidade concreta de alterar o que está na pauta de votações.

O processo parlamentar é composto de várias outras etapas, sendo o input inicial somente uma delas. Raros, porém, são os trabalhos que se dedicaram a olhar para o processo de participação dos parlamentares no processo legislativo, na formatação das matérias que ganham corpo ao transcorrer do longo percurso que percorrem até angariarem apoio necessário para virar lei. Basta notar que dificilmente propostas de lei são aprovadas com o mesmo conteúdo sugerido por seu propositor (Freitas, 2010).

Se o objetivo é compreender como a atividade legislativa pode nos ajudar nessa empreitada, será útil atentar para a discussão que vê nas comissões da Câmara e do Senado um dos lócus mais importantes da atividade parlamentar. Isso porque, como é sabido, no Brasil as comissões constituem a primeira instância pela qual os projetos de lei são debatidos após serem distribuídos pela Mesa Diretora das casas legislativas. Em um segundo momento, as propostas de lei podem vir a passar pelo crivo do plenário, onde também a comissão não se furta de participar ativa e diretamente do processo (Freitas, Medeiros e Moura, 2008; Freitas, 2010) ${ }^{14}$. Em suma, constituem elas instâncias da maior importância na atividade legislativa, se fazendo presente em todas as etapas do processo de apreciação das matérias. Assim, parte da literatura inserida no debate das décadas de 1990 e 2000 tenta apreender sua importância frente sua relação com o Poder Executivo.

Inseridos nesse debate, autores como Pereira e Mueller (2000) afirmam, por exemplo, que a importância e a efetividade das Comissões Permanentes variam em

${ }^{14}$ Uma das novidades que vieram na esteira da promulgação da Carta de 1988, o poder conclusivo ou terminativo, dotou as Comissões de importância ainda mais substantiva na atividade legislativa. Essa mudança constitucional e regimental possibilitou que, por uma questão de ordem prática - acelerar o processo de avaliação e aprovação de uma lei, com fins a aumentar a eficiência do trabalho legislativo -, as comissões pudessem deliberar sobre as matérias sem a necessidade de que as mesmas fossem avaliadas pelo plenário. Esse instituto aumentou ainda mais o poder das comissões, fazendo delas, nesses casos, a instância única da atividade legislativa.

(http://www.senado.gov.br/portaldoservidor/jornal/jornal118/processo_legislativo.aspx) 
relação direta ao seu grau de alinhamento à agenda do Executivo. Se, por um lado, divergências entre as preferências destes órgãos técnicos e os desejos do governo diminuem a margem de manobra das mesmas sobre as propostas legislativas, por outro, no predomínio de consenso, as comissões passam a ser valorizadas pelo Executivo. Tanto seria assim que, nas palavras dos autores, "a existência e o funcionamento do sistema de comissões está subordinado às preferências do Executivo" (Pereira e Muller, 2000, p. 46). Argumentam que em virtude dos amplos poderes de que dispõe o Executivo para contornar as Comissões, ou forçá-las a cooperar, "ou as comissões estão cumprindo uma tarefa que é do interesse do Executivo, ou esta tarefa lhe é indiferente" (Pereira e Mueller, 2000, p. 46). Isso porque supõem que as preferências do Executivo expressas na maioria formada por ele - devem se refletir no princípio de proporcionalidade que rege a composição das comissões.

Ora, se tal análise não pode ser descartada a priori - dado que nem mesmo sabemos ainda se, na prática, as comissões dão espaço para a atuação positiva da nãocoalizão $^{15}$, , vale frisar que outros pesquisadores formulam a hipótese contrária para o caso norte-americano. Esses autores afirmam que são as comissões que se sobrepõem às preferências do Executivo, com as maiorias nelas trabalhando para fazer valer suas próprias preferências (Cox e McCubbins, 1993).

Também no Brasil, a literatura especializada aponta que as comissões constituem um importante lócus para a participação das minorias. Abrucio (1998) enfatiza que um dos problemas que afeta o Executivo Federal está diretamente relacionado à incapacidade deste em controlar os cargos em comissão. Assim, ao comentar os primeiros anos de nosso mais recente período democrático, o autor afirma que "o presidente não controlava grande parte das comissões no que tange à distribuição

\footnotetext{
${ }^{15}$ Para a atuação positiva da maioria legislativa nas comissões, ver Freitas (2010).
} 
e ao posterior exercício dos cargos" (Abrucio, 1998, p. 182-83). Como se vê, as comissões podem ser um foco de atuação importante para aqueles que se encontram na não-coalizão façam frente ao governo, fazendo uso destas para moldar as leis que vem a ser aprovadas.

Freitas, Medeiros e Moura (2008) apontam que, dentre todas as propostas do Poder Executivo aprovadas entre 1988 e 2006, 60\% delas sofreram alterações. O recorte que abrange somente as medidas propostas pelo Executivo Federal tem escopo claro: se o governo é tido como o legislador por excelência, é nos projetos de sua autoria que podemos notar de que maneira o Legislativo participa do processo de formatação das leis. Neste caminho, se, por um lado, esses dados mostram haver espaço para que alterações tomem lugar na arena legislativa, denotando a importância dessa instância e dos ajustes que nela se dão, nada foi dito a respeito de quem empreende essas alterações. As evidências levantadas no artigo citado apontam para o fato de que a maior parte das alterações se dá no interior do processo legislativo, mas especificamente no âmbito das comissões. E isso acontece dessa forma mesmo quando é feito uso da urgência ${ }^{16}$. Vale lembrar que o instituto da urgência tem a peculiaridade de retirar os projetos das Comissões na qual se encontram sendo debatidas e levá-las ao plenário.

\footnotetext{
${ }^{16}$ A questão do rito de tramitação é um dos elementos mais destacados pela literatura ao afirmar a preponderância do Executivo e do plenário sobre as matérias submetidas ao Legislativo. O Presidente da República tem assegurado pelo artigo 64 da Constituição Federal o direito de solicitar regime de urgência constitucional para os projetos de sua autoria. A urgência constitucional estabelece prazo de 45 dias para a votação na Câmara e mais 45 dias para a votação no Senado, passando a trancar a pauta legislativa quando expirado este prazo. Desse modo, a medida reduz significativamente o tempo de tramitação das matérias nas comissões, que têm, assim, sua atuação restringida. Além disso, o art. 155 do RICD estabelece o direito do Legislativo de solicitar urgência urgentíssima aos projetos. Esta medida, quando aprovada, retira imediatamente a matéria das comissões e a submete ao plenário da Casa. O requerimento de urgência urgentíssima pode ser feito por dois terços da Mesa Diretora, dois terços dos membros da comissão relevante e por um terço dos membros do plenário ou por líderes que representem este número. Uma vez aprovada à urgência, a proposta só pode receber emendas da comissão, de um quinto dos membros da Câmara ou de líderes que representem esse número. Deve se ressaltar, no entanto - e este ponto é fundamental -, que o pedido de urgência não retira a prerrogativa das comissões a que o projeto foi despachado de apresentar seu parecer, sendo este elaborado, em uma sessão, e proferido oralmente em plenário. Assim, para projetos de lei ordinária, tanto o Executivo quanto o Legislativo podem alterar o rito ordinário de tramitação solicitando urgência para as matérias.
} 
Diz-se que este mecanismo constitui uma arma do Executivo para acelerar os projetos de seu interesse (Figueiredo e Limongi, 1998), ao passo que também pode ser empregado como uma ferramenta estratégica, já que seu uso possibilita ao Presidente da República driblar as comissões, caso o queira. No entanto, mesmo com o uso desse artifício, o trabalho identifica que a maior parte das alterações empreendidas nos projetos tem origem nas comissões (uma média de 73.3\% para todo período analisado).

Outros estudiosos da arena parlamentar vão no mesmo caminho ao afirmar a importância dessa instância. Krehbiel (1988), por exemplo, mostra que o poder das Comissões pode se dar tanto na forma negativa como na positiva. Já para Shepsle e Weingast (1987), são as regras que pautam a seqüência do processo legislativo, e dessa forma fazem das Comissões uma instância relevante. Neste sentido, o poder negativo das comissões se assentaria na sua habilidade de se impor como obstáculo, paralisando ou rejeitando a apreciação das matérias em debate. Por outro lado, o poder positivo se constituiria na capacidade efetiva de influenciar os rumos das políticas (Smith e Deering, 1997, p. 9). Para os fins desta pesquisa, importa a interpretação aventada por Mattson e Strom (1995), alegando que dentre as prerrogativas positivas formais das Comissões encontram-se o direito de iniciar legislação, o controle sobre a pauta das comissões, a possibilidade de reescrever os projetos de lei, assim como sua capacidade de obter informação dos demais atores via pedidos de informação. No Brasil, as Comissões contam com todas essas prerrogativas, mas seu controle sobre a pauta não é garantido, em virtude do pedido de urgência ter a prerrogativa de retirar as matérias da comissão e colocá-las em votação no plenário.

Mas de que maneira os atores podem atuar no sistema de comissões do Parlamento brasileiro? Dado que as chances reais de participação dos atores depende das normas em vigor, falaremos um pouco sobre isso. 
No sistema de comissões brasileiro as minorias têm um espaço de participação constitucionalmente garantido ${ }^{17}$. Seus membros podem tanto ocupar cargos ordinários dentro da mesma, como também cargos de chefia das atividades. Nesse sentido, o relator da comissão ocupa o posto mais importante, pois é ele quem dá o relatório final debatido por seus membros, aceita ou não as alterações propostas e propõe ou não alterações aos projetos.

Para dar um dado inicial que denota a força que esse cargo tem, de todas as 2024 alterações empreendidas nos projetos que vieram a se tornar lei no período, 1424 delas, ou seja, $70.4 \%$, foram empreendidas por relatores. Logo, tendo em vista o poder que esse cargo dá a seus ocupantes, seria natural esperar que o governo fizesse o máximo para ocupar todas as relatorias, e de fato tivesse sucesso nessa empreitada, já que sua base de apoio costuma constituir a maioria formal das cadeiras.

Visto por outro ângulo, se o sistema pluripartidário brasileiro induz o Executivo a formar coalizões para obter a maioria legislativa necessária à aprovação de seus projetos, e não há certeza que seus parlamentares votarão $100 \%$ das vezes de acordo com suas diretrizes do Governo, nada mais normal que a Coalizão tivesse interesse real em monopolizar estes cargos. Seria uma forma de afiançar que os resultados das políticas de interesse dos partidos da Coalizão fossem garantidos. Mais que isso, se o parecer do relator é sempre a palavra final da comissão, e na maioria dos casos as alterações provindas desta constituem a maior parte das modificações feitas nos projetos de lei aprovados, garantir esse cargo seria uma forma de garantir os ajustes necessários para que os anseios dos partidos da Coalizão fossem contemplados. Por outro lado, serviria como um artifício para assegurar que a unidade da própria coalizão fosse

\footnotetext{
${ }^{17}$ Segundo a Constituição de 1988, a distribuição dos cargos que comporão as comissões deve ser feita de maneira proporcional. Assim, todos parlamentares têm a chance de atuar nessa esfera (Art. 8, § 3; Art. $25 \S 1^{\circ}$, RICD).
} 
mantida. Isso porque, em certa medida, a divisão dos cargos e pastas ministeriais entre participantes da Coalizão os possibilita moldar a agenda proposta pelo partido do presidente, de forma a "acertar os ponteiros" que possibilitem que os interesses de todos partidos abaixo do "guarda-chuva" da Coalizão sejam garantidos. Posto de outra forma, não seria estranho pensar que a unidade dos partidos da Coalizão presidencial gire em torno de consensos mínimos acerca das políticas a serem adotadas. Assim, como bem colocou a literatura, "quando a política se encontra longe do ponto ideal de um partido [do partido do presidente, formador da coalizão], este tem interesse em trocar ministérios por uma política mais próxima de seu ponto ideal (...), embora não haja incerteza quanto à distribuição de pastas, os resultados de políticas específicas são incertos e os partidos são avessos aos riscos" (Cheibub, Przeworski e Saiegh, 2002, p. 191).

Ao dissertarem sobre a formação da agenda do governo, Figueiredo e Limongi (2009) afirmam que "qualquer que seja o modelo que se assuma do processo decisório no interior de uma coalizão, (...) de alguma forma os partidos da coalizão participam da elaboração dessa agenda" (Figueiredo e Limongi, 2009, p. 88). O que estou querendo enfatizar é que não seria estranho pressupor que o controle das propostas que saem dos ministérios, e a formatação que permite trazê-las mais próximas dos pontos ideais dos atores em jogo, fosse alvo de grande interesse dos membros da coalizão - pois deles dependeria sua estabilidade e permanência. Se a unidade das coalizões é importante para sua estabilidade e, sobretudo, para o Executivo colocar em prática seu plano de governo, os ajustes que possibilitam a permanência deste agrupamento são fundamentais para tal desenrolar. Neste sentido, as alterações feitas nos projetos constituem-se em uma ferramenta que pode minimizar os custos de coordenação da coalizão. 
A relatoria, assim, parece ser mais importante para os membros da coalizão, dado que estes, assim como o Executivo, parecem ter mais a perder com a falta de unidade do que os membros da não-coalizão. Visto por outro lado, se para o governo majoritário este posto é importante para evitar problemas de coordenação indesejados, também seria esperado que a não-coalizão buscasse ocupar esses cargos. Isso porque através deles está aberto não só um caminho eficaz para participar do processo de formatação das leis, mas também um caminho para desestabilizar o governo e, com isso, suas chances de permanência no poder. Assim, o esperado é que o governo tente bloquear o acesso da não-coalizão a este posto. Mas será que isso ocorre?

Para encontrar essa resposta é importante observar se estes parlamentares da não-coalizão são de fato indicados para relatar as matérias. Sendo indicados, só conseguimos aferir se, de fato, têm relevância sua indicação quando estes relatores conseguem ir até o final do processo; é dizer, têm seu parecer aprovado - seja proferido oralmente em plenário ou não -, ou rejeitado. 


\subsection{Participação dos membros da não-coalizão na tramitação dos projetos}

Neste estudo ficaram de fora as Medidas Provisórias (MPs) anteriores à Emenda Constitucional $n^{0} 32$, de $2001^{18}$, uma vez que sob a regra antiga as MPs podiam ser reeditadas indefinidamente, e as modificações que estas sofriam apareciam muitas vezes como "reedição com alterações", sem que as alterações, e quem as propunham, fossem explicitadas. Daí a exclusão das autorias de relatorias das MPs que vigoravam com a regra antiga das análises que tomarão lugar daqui em diante. Isso não foi feito antes porque, no cálculo das autorias dos projetos, considerou-se apenas a primeira edição das Medidas Provisórias que foram editadas no período anterior à EC $\mathrm{n}^{\mathrm{o}} 32$, evitando o "inchaço" na autoria de projetos da coalizão de governo. Agora, porém, aqueles casos são contados com as relatorias indicadas aos 2668 projetos que foram transformados em lei.

Neste período, dos 10584 relatores indicados para dar parecer sobre as matérias aprovadas, 1904 deles não se pronunciaram, e aqui os motivos podem ser diversos, desde morte, troca inusitada, esgotamento do prazo para que o parecer fosse dado até fim da legislatura. Assim, o foco da análise se restringiu apenas àqueles pareceres tomados por válidos (os que foram aprovados, rejeitados ou dados oralmente em plenário), com intuito de averiguar em que medida os parlamentares da não-coalizão puderam participar do processo. Chamei essas relatorias de "relatorias válidas".

Para contabilizar e agrupar os parlamentares, por sua vez, a opção foi considerar os partidos a que estes estavam filiados na data de aprovação ou rejeição dos pareceres. Isso porque agrupar os parlamentares naqueles partidos em que se encontravam no dia

\footnotetext{
${ }^{18}$ A partir dessa data foram alteradas as regras de tramitação das Medidas Provisórias, limitando a uma o número de reedições possíveis e levando a matéria, quando não apreciada no período de 60 dias (prorrogáveis por mais 60), a trancar a pauta, forçando assim sua votação.
} 
da posse seria mais arriscado, dado que as migrações de partido não são incomuns no Brasil (Freitas, 2009).

Assim, nosso universo compreende as 7677 relatorias válidas (aprovadas, rejeitadas ou proferidas oralmente em plenário) de todos os Projetos de Lei Ordinária (PL), Medidas Provisórias (MP) posteriores à Emenda Constitucional $\mathrm{n}^{\mathrm{o}} 32$ e Projetos de Lei Complementar (PLP) aprovados no período. A tabela abaixo mostra como as indicações das relatorias válidas foram distribuídas entre os grupos ao longo das legislaturas.

Tabela 2.1: Relatorias válidas nas leis aprovadas, por tipo de governo

\begin{tabular}{|c|c|c|}
\hline & Governo Majoritário & Governo Minoritário \\
\hline Coalizão & $4194(71,2 \%)$ & $651(36,5 \%)$ \\
\hline Não-Coalizão & $1699(28,8 \%)$ & $1133(63,5 \%)$ \\
\hline Total & $5893(100 \%)$ & $1784(100 \%)$ \\
\hline
\end{tabular}

Fonte: Banco de Dados Legislativos, Cebrap.

Como podemos notar, quando olhamos para as indicações de relatorias que tiveram parecer válido, o espaço aberto para a participação da não-coalizão é nítido. Sua participação no processo é proporcionalmente ainda maior que a quantidade de projetos de sua autoria que são aprovados. Das 7677 indicações de relatorias válidas dos projetos que vieram a se tornar lei, $2832(36,9 \%)$ delas foram ocupadas por parlamentares da não-coalizão. Mas se na autoria dos projetos ficou evidente que o governo detém poder de agenda, dado que a maior parte dos projetos aprovados tanto nos governos majoritários quanto nos minoritários eram sempre de autoria do governo, aqui a coisa muda um pouco de figura. Como podemos notar, a maior parte das relatorias exercidas 
tanto em governos majoritários (71.2\%) quanto em governos minoritários (63.5\%) se concentram exatamente nas mãos do grupo de partidos que, fazendo parte ou não da coalizão de governo, detêm a maioria formal das cadeiras. Esses dados já foram apresentados por Freitas (2010), que trata, no entanto, apenas dos projetos apresentados pelo Executivo.

É de se notar um indicativo da proporcionalidade existente entre participação e tamanho dos atores é notável como mostra a tabela abaixo. Nela se observa a proporção de cadeiras que o grupo obteve no Congresso, revelando que parlamentares da nãocoalizão têm um nível de participação muito próximo ao seu tamanho relativo. Neste ponto do processo, a participação dos atores faz jus à proporção de cadeiras que representam $^{19}$, ao invés de depender diretamente da lógica coalizão/não-coalizão (governo/oposição).

Tabela 2.2: Média da proporção das cadeiras $\mathrm{CD} / \mathrm{SF}$

\begin{tabular}{|c|c|c|}
\hline & $\begin{array}{c}\text { \% cadeiras do Governo } \\
\text { Majoritário }\end{array}$ & $\begin{array}{c}\text { \% cadeiras do Governo } \\
\text { Minoritário }\end{array}$ \\
\hline Coalizão & $65,9 \%$ & $34,5 \%$ \\
\hline Não-Coalizão & $34,1 \%$ & $65,5 \%$ \\
\hline Total & $100 \%$ & $100 \%$ \\
\hline
\end{tabular}

Fonte: Banco de Dados Legislativos, Cebrap.

\footnotetext{
${ }^{19}$ A média da proporção de cadeiras de cada um dos grupos expostos na tabela acima foi contabilizada tiramndo-se a porcentagem do número de cadeiras dentro de cada coalizão e cada casa legislativa. Assim somam-se as porcentagens dos partidos da não-coalizão e coalizão em cada uma das coalizões minoritárias e majoritárias

Somam-se as porcentagens do tamanho de cada um dos grupos na câmara e no senado e tira-se amédia entre ambas as casas.
} 
Ambas as tabelas sinalizam que a participação dos atores nesse estágio do processo legislativo está muito próxima de seu tamanho relativo.

Nos governos minoritários, onde a não-coalizão ajuda o governo a obter a maioria legislativa para governar, a proporção entre número de relatorias ocupadas e tamanho do grupo é levemente abaixo do seu tamanho. A não-coalizão ocupa $63.5 \%$ das relatorias, pouco abaixo da proporção de cadeiras que ocupa (65.5\%). Nos governos majoritários, onde em tese maioria de governo e maioria para governar seriam coincidentes, mesmo assim, a não-coalizão, que ocupa $34.1 \%$ da cadeiras, é responsável por $28.8 \%$ da relatorias. Assim, mesmo que o governo seja responsável por ocupar mais relatorias do que, proporcionalmente, lhe caberiam, a atuação da não-coalizão é marcante.

Se a indicação de parlamentares da não-coalizão para relatar as matérias indica abertura de espaço à participação desses atores, ela por si só não garante que seus pareceres serão levados em conta. E é justamente a aprovação destes pareceres que faria da atuação da não-coalizão promissora na perspectiva da inclusividade do sistema.

Não se trata de descartar, aqui, a hipótese de que os debates travados dentro da comissão e os pareceres dos relatores, mesmo tendo sido rejeitados, moldem o que vem a se tornar lei, apesar de somente ser possível se confirmar a efetividade de sua participação quando seu parecer é aceito, e, em grande medida, quando de fato resulta na alteração dos projetos a redundar em normas jurídicas. A questão tampouco é afirmar que a anuência do relator ao teor dos projetos propostos, sem interpor alterações, possa significar sua omissão no processo legislativo, pois não temos motivos para desacreditar na ocorrência de temas consensuais. Aliás, um consenso mínimo é o esperado para que uma proposição de iniciativa conjunta venha se tornar lei. 
Seguindo a lógica de que, em governos majoritários, a coalizão de governo não precisaria contar com o apoio da não-coalizão para formar a maioria legislativa para aprovar seus projetos, esperamos que grande parte dos pareceres dos relatores desse grupo seja rejeitado. Quando o governo é minoritário, já que conta com a não-coalizão para formar a maioria legislativa necessária, esperamos que uma parcela menor dos pareceres da não-coalizão seja aceita, mas que o governo se faça prevalecer já que sabemos a força que esse cargo tem, e quão importante é seu monopólio.

A pergunta que deve ser feita é: por que a base de governo majoritária deixaria espaço para participação da não-coalizão? Colocamos a questão, pois, se, como vimos, um parlamentar da minoria tem praticamente a mesma chance de ser indicado a relatar uma matéria, será que a aprovação de seu parecer segue o mesmo caminho?

Dos 7677 pareceres válidos, apenas 38 deles foram rejeitados. Sendo $28(0.5 \%)$ nos governos majoritários e $10(0.6 \%)$ nos minoritários. Não há praticamente diferenças nesses números quando se trata de pareceres rejeitados dos membros da não-coalizão $(0.5 \%)$ ou da coalizão $(0.5 \%)$ em governos majoritários, tanto quanto nos governos minoritários $-(0.4 \%)$ e $(0.8 \%)$ respectivamente. Isso indica que seguem válidas as chances de participação da não-coalizão, conforme descrevemos acima.

As indicações das relatorias, como se vem mostrando até então, parecem apontar para existência de certa proporcionalidade na participação dos atores ao longo do processo de formatação de um projeto que se tornará lei. Mas poderíamos dizer que a participação dos relatores segue uma lógica diferente nos projetos de iniciativa privativa do Executivo? Tratando-se de matérias de cunho muitas vezes administrativo, seria de se esperar que o espaço aberto àqueles que não se filiam aos partidos da base do governo fosse vetada. Mas não é isso que na prática acontece. 
Tabela 2.3: Relatorias válidas nas leis de iniciativa privativa do Executivo, por tipo de governo

\begin{tabular}{|c|c|c|}
\hline & Governo Majoritário & Governo Minoritário \\
\hline Coalizão & $1264(70,5 \%)$ & $250(36,2 \%)$ \\
\hline Não-Coalizão & $528(29,5 \%)$ & $441(63,8 \%)$ \\
\hline Total & $1792(100 \%)$ & $691(100 \%)$ \\
\hline
\end{tabular}

Fonte: Banco de Dados Legislativos, Cebrap.

O panorama segue o mesmo que o exposto anteriormente, com a não-coalizão participando um pouco menos $(29.5 \%)$ do que lhe poderia ser proporcionalmente exigido frente a porcentagem de cadeiras que ocupa (34.1\%), nos governos majoritários, e um pouco a mais quando (63.8\% e $65.5 \%$ respectivamente) quando o governo é minoritários. Em governos minoritários a coalizão tem sobre-representada sua participação nas relatorias. Mesmo assim, nesses governos participa em $63.8 \%$ das relatorias , contra $65,5 \%$ das cadeiras que ocupa. Mas e nas leis de iniciativa conjunta? Dá-se a mesma coisa? A reposta é: sim.

Tabela 2.4: Relatorias válidas nas leis de iniciativa compartilhada, por tipo de governo

\begin{tabular}{|c|c|c|}
\hline & Governo Majoritário & Governo Minoritário \\
\hline Coalizão & $2930(71,4 \%)$ & $401(36,7 \%)$ \\
\hline Não-Coalizão & $1171(28,6 \%)$ & $692(63,3 \%)$ \\
\hline Total & $4101(100 \%)$ & $1093(100 \%)$ \\
\hline
\end{tabular}

Fonte: Banco de Dados Legislativos, Cebrap. 
Continua havendo uma participação da não-coalizão no processo, da mesma forma que havíamos descrito anteriormente. Mas, e nas leis que são propostas pelos partidos da não-coalizão? Em teoria, segundo uma lógica do conflito, estas representam interesses diferentes das leis propostas por parlamentares dos partidos que compõem a coalizão de governo. Será que devemos esperar mudanças aqui?

Tabela 2.5: Relatorias válidas nas leis de autoria da não-coalizão, por tipo de governo

\begin{tabular}{|c|c|c|}
\hline & Governo Majoritário & Governo Minoritário \\
\hline Coalizão & $674(66,4 \%)$ & $109(34,2 \%)$ \\
\hline Não-Coalizão & $341(33,6 \%)$ & $210(65,8 \%)$ \\
\hline Total & $1015(100 \%)$ & $319(100 \%)$ \\
\hline
\end{tabular}

Fonte: Banco de Dados Legislativos, Cebrap.

Qual a novidade em como participam os atores da não-coalizão nos projetos de autoria deles mesmos? O que chama a atenção aqui é paridade quase perfeita entre porcentagem de cadeiras que o os parlamentares da coalizão/não-coalizão ocupam e sua participação. Assim, quando os governo são majoritários, a minoria tem $34.1 \%$ das cadeiras e $33.6 \%$ das relatorias, e, quando o governo é minoritário a nãocoalizão tem $65.5 \%$ das cadeiras e $65.8 \%$ das relatorias.

O Gráfico 2, a seguir, mostra qual a porcentagem de relatorias é angariada pelos partidos que estão fora da coalizão de governo, frente à proporção de assentos que 
ocupam no período, nos projetos de autoria dos diferentes grupos que mostramos acima, a contar pela porcentagem de cadeiras na data inicial de cada coalizão.

Gráfico 2.1: Relatorias válidas da não-coalizão vs \% cadeiras da não-coalizão

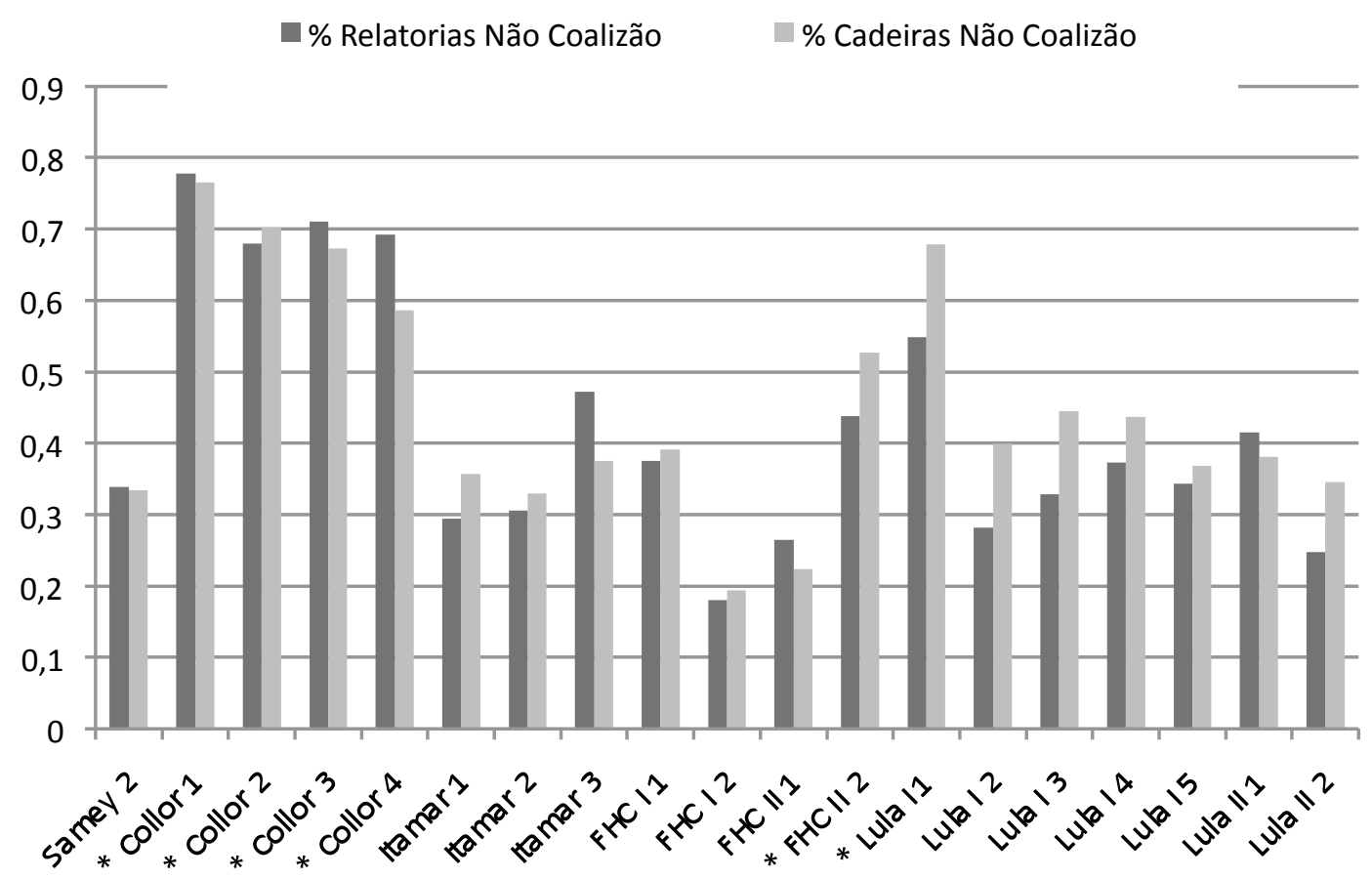

Fonte: Banco de Dados Legislativos, Cebrap.

Se ao participar das discussões dos projetos a não-coalizão tem a chance de emitir sua opinião de forma proporcionalmente muito similar ao número de cadeiras que ocupa, aqui temos um ponto. No que tange a participação, os atores são ouvidos, podem expressar sua opinião e essa é levada em conta na grande maioria das vezes.

Apesar da indicação das relatorias se constituir em uma importante ferramenta para entender como se dão os debates dentro do Congresso brasileiro, ele é apenas um 
indicador das expressões dos parlamentares. É dizer, ser ouvido é importante, mas disso não podemos concluir que suas opiniões são levadas em conta.

Se muitos dos pareceres dos relatores são pela aprovação do projeto original, poderiam estar eles não mais que ratificando o que foi proposto por seu autor. Se como vimos, a maior parte do que é proposto vem das mãos da coalizão, talvez esse indicador não nos dissesse muita coisa. Mas não é isso que ocorre. Como notaremos, quando comparamos o que propõem esses relatórios que opinam sobre os projetos, veremos que muitas das vezes a não-coalizão propõem alterações aos mesmos, e na mesma ordem, proporcionalmente, ao que o faz a coalizão. Logo, através das alterações que modificam o conteúdo do que é proposto, poderemos notar como os parlamentares da não-coalizão atuam de forma positiva e mensurável no processo parlamentar. É o que veremos agora. 


\subsection{A formatação das leis}

Das 1919 leis aprovadas no período ${ }^{20}, 1205$ foram alteradas, ou $62.8 \%$ do total. No gráfico abaixo podemos ver as leis alteradas nos governos majoritários e minoritários. Podemos notar que a maior parte de tudo que virou lei no período foi modificado pelo parlamento antes de ser aprovado.

\section{Gráfico 2.2: Alterações, por tipo de governo}

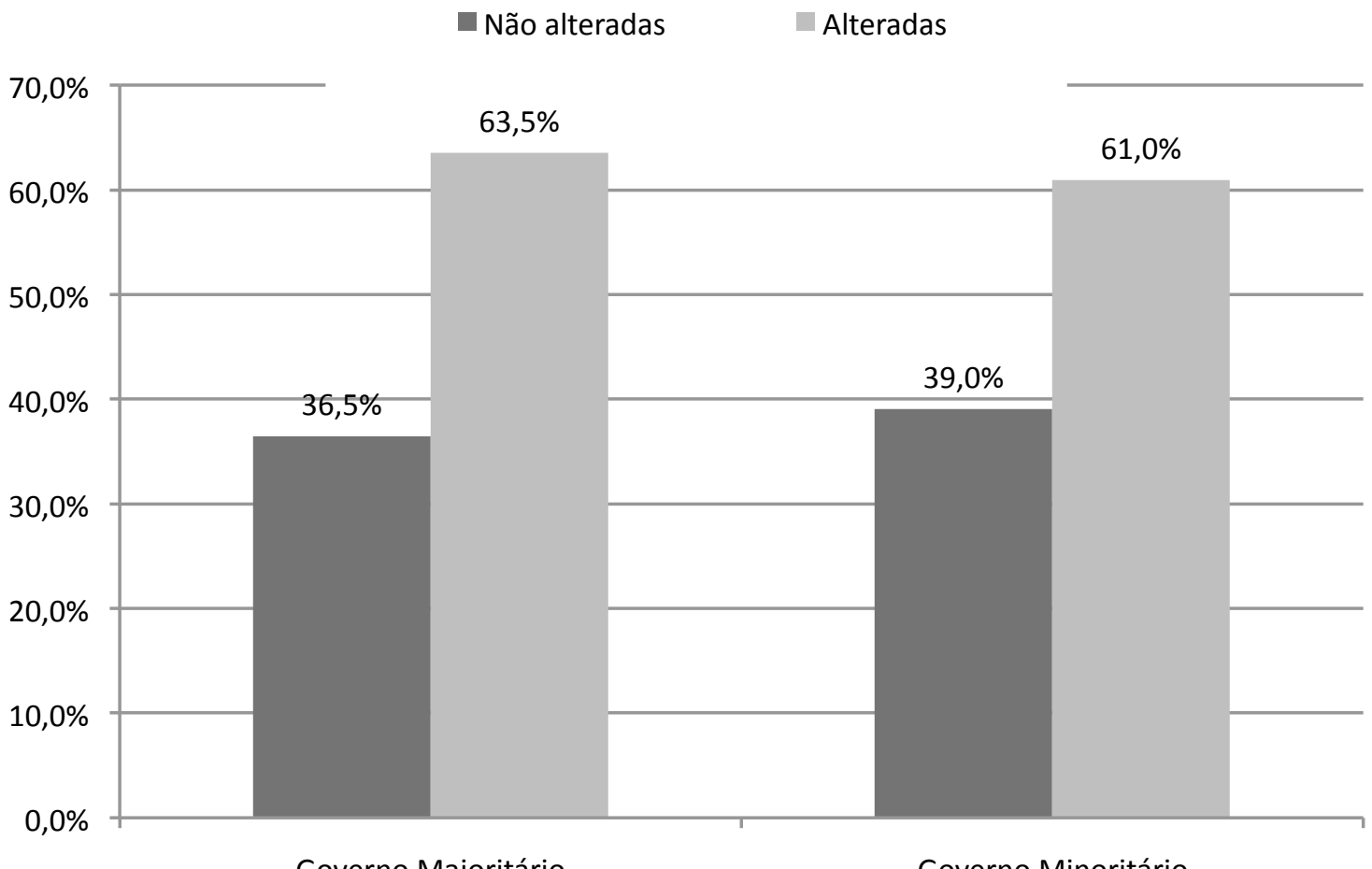

Fonte: Banco de Dados Legislativos, Cebrap.

Não há praticamente diferenças entre os tipos de governos quando o assunto é alteração, em ambos governos se altera muito. O gráfico acima vem a reafirmar que a atuação dos parlamentares é grande. Mas que tipo de alterações são essas? Quem as fazem, e, projetos de quais grupo são passíveis de sofrer mais alterações?

\footnotetext{
${ }^{20}$ Nesse cálculo incluímos todos os projetos de lei com exceção dos projetos de "homenagem". Excluímos as Medidas Provisórias anteriores a Emenda Constitucional número 32, pelo motivo exposto anteriormente.
} 
Para entendermos se os parlamentares da não-coalizão participam positivamente nas leis aprovadas, temos de saber se os pareceres dos relatores ou dos parlamentares seja na comissão ou no plenário das casas legislativas de fato foram imputaram mudanças nas leis aprovadas. Isso porque, muitas vezes alterações são propostas em uma comissão e derrubadas em outra, ou mesmo no plenário. Também, alterações são aprovadas na Câmara e são derrubadas no Senado, e vice-versa a depender do rito de tramitação de cada tipo de matéria.

O processo parlamentar de tramitação das matérias é composto por várias etapas distintas. De forma sucinta, um projeto pode receber e ter aprovada ao longo do processo mais de uma alteração. Na prática, alterações vão sendo aprovadas e, em grande parte das vezes, ao final do processo, quando o projeto sofre uma quantidade grande de alterações, costuma-se apresenta as diversas alterações na forma de um projeto substitutivo ao projeto original. Este, no mais das vezes, engloba as alterações que angariaram consenso ao longo da tramitação dos projetos de lei. Mas tanto o substitutivo quanto emendas, podem ser propostos em diversos momentos da tramitação das matérias ${ }^{21}$. O modo como se nomeiam as alterações não faz referência direta a seu conteúdo. Ao melhor dizendo, a probabilidade de uma emenda desconfigurar o teor do projeto de lei apresentado é tão grande quanto a de um substitutivo ou uma emenda proposta a um substitutivo. Sem uma análise mais detida do teor de cada uma dessas

\footnotetext{
21 Como exposto no artigo 118, § 4o do Regimento Interno da Câmara dos Deputados: "Emenda substitutiva é a apresentada como sucedânea a parte de outra proposição, denominando-se "substitutivo" quando a alterar, substancial ou formalmente, em seu conjunto; considera-se formal a alteração que vise exclusivamente ao aperfeiçoamento da técnica legislativa." Vale ainda notar que os projetos substitutivos das comissões têm precedência sobre a proposta original no momento da votação, como definido no § 4o do artigo 138 do Regimento Interno da Câmara dos Deputados (RICD). No entanto, ao nosso ver, não seria correto inferir que um projeto substitutivo altere mais a essência de um projeto do que uma emenda, ou vice-versa. Uma vez que se dá o título de substitutivo a projetos que alterem não só "substancial" como também "formalmente" o projeto21. Ou seja, o conteúdo do projeto pode não ser alterado, e mesmo assim as alterações serem aprovadas na forma de um projeto substitutivo. Vale lembrar ainda que, nas diversas rodadas de votação, ainda é possível alterar o teor de um projeto substitutivo via apresentação de emendas ao mesmo.
} 
alterações é impossível afirmar em que grau cada uma delas reformula o teor do projeto original. Por esse motivo, contaremos a partir de agora com todas as alterações empreendidas nos projetos que se tornaram, sejam elas de que tipo forem.

Contamos então com um total de 1205 projetos alterados, na qual foram empreendidas 2017 alterações.

Tabela 2.6: Alterações nas leis aprovadas, por tipo de governo

\begin{tabular}{|c|c|c|}
\hline & Governo Majoritário & Governo Minoritário \\
\hline Coalizão & $1056(67,9 \%)$ & $159(34,5 \%)$ \\
\hline Não-Coalizão & $500(32,1 \%)$ & $302(65,5 \%)$ \\
\hline Total & $1556(100 \%)$ & $461(100 \%)$ \\
\hline
\end{tabular}

Fonte: Banco de Dados Legislativos, Cebrap.

Pode-se destacar que no computo geral, os dados de alteração continuam seguindo a mesma lógica que vimos desde as relatorias. Nos governos majoritários, a proporcionalidade entre participação e tamanho dos atores não chega a ser perfeita, ficando pouco abaixo do número de cadeiras ocupado pela não-coalizão. Mas é surpreendente que mesmo sendo os governos majoritários, ainda assim permitam que as propostas sejam alteradas na ordem de $32.1 \%$ pela não-coalizão. Já a participação existente nos governos minoritários, essa sim é diretamente proporcional ao tamanho dos atores. Nesses governos a não-coalizão é responsável por $65.5 \%$ de todas as alterações, na medida perfeita da proporção de cadeiras que ocupa; $65.5 \%$. Através desses dados, nesses governos, poderíamos dizer que existe uma correlação direta entre participação e proporção de cadeiras. Dito de outra forma a representação aqui é 
proporcional. Mas para que possamos nos certificar em que medida isso ocorre, analisaremos agora como a participação da não-coalizão se dá nos projetos de iniciativa privativa do presidente, de iniciativa compartilhada e por fim nos projetos de autoria da não-coalizão.

Tabela 2.7: Alterações nas leis de iniciativa privativa do Executivo, por tipo de governo

\begin{tabular}{|c|c|c|}
\hline & Governo Majoritário & Governo Minoritário \\
\hline Coalizão & $236(65,4 \%)$ & $47(34,3 \%)$ \\
\hline Não-Coalizão & $125(34,6 \%)$ & $90(65,7 \%)$ \\
\hline Total & $361(100 \%)$ & $137(100 \%)$ \\
\hline
\end{tabular}

Fonte: Banco de Dados Legislativos, Cebrap.

Devemos nos recordar aqui que quando estudamos a autoria dos projetos ficou nítido como o poderes exclusivos do presidente importavam para pautar a agenda. Ali sim, a quantidade numérica formal dos atores não fazia diferença, na medida que até mesmo em governos minoritários o presidente era responsável pela maior parte de tudo que vinha a se tornar lei. Mas como dissemos, no que tange a participação isso não nos parece querer dizer muito, uma vez a aprovação de uma proposta de um grupo A ou B não determina como pode se dar com participação efetiva da não-coalizão, como nos apontam esses dados. Notamos aqui, novamente, uma correlação quase perfeita entre proporção de cadeiras e alterações nos projetos. Cabe notar que estamos tratando aqui apenas de projetos de iniciativa privativa do presidente, que versam basicamente sobre a parte administrativa e a condução das políticas de governo. E mesmo assim, há 
participação expressiva da não-coalizão. Mas vejamos agora quem altera as propostas de iniciativa conjunta.

Tabela 2.8: Alterações nas leis de iniciativa compartilhada, por tipo de governo

\begin{tabular}{|c|c|c|}
\hline & Governo Majoritário & Governo Minoritário \\
\hline Coalizão & $819(68,6 \%)$ & $112(34,6 \%)$ \\
\hline Não-Coalizão & $375(31,4 \%)$ & $212(65,4 \%)$ \\
\hline Total & $1194(100 \%)$ & $324(100 \%)$ \\
\hline
\end{tabular}

Fonte: Banco de Dados Legislativos, Cebrap.

Aqui novamente os valores se repetem, no entanto em governos majoritários a não-coalizão é algo subrepresentada, em relação ao seu tamanho. Já nos governos minoritários isso não ocorre.

Passemos agora a ultima tabela de alterações, se o governos faz frente as propostas da não-coalizão, aqui é onde esperamos que sua participação seja mais incisiva. E a da não-coalizão, menos. Mas como veremos não é isso que acontece.

Tabela 2.9: Alterações nas leis da não-coalizão, por tipo de governo

\begin{tabular}{|c|c|c|}
\hline & Governo Majoritário & Governo Minoritário \\
\hline Coalizão & $190(64,6 \%)$ & $34(34,3 \%)$ \\
\hline Não-Coalizão & $104(35,4 \%)$ & $65(65,7 \%)$ \\
\hline Total & $294(100 \%)$ & $99(100 \%)$ \\
\hline
\end{tabular}

Fonte: Banco de Dados Legislativos, Cebrap. 
Novamente aqui a variação da participação versus proporcionalidade de cadeiras, chega a ser entediante. É, neste caso, absolutamente proporcional.

O próximo gráfico mostra como essa distribuição se dá ao longo das coalizões. Veremos aqui em que medida existe relação entre a proporção de alterações empreendidas pela não-coalizão e o número de cadeiras que ocupa, em cada uma das coalizões.

Gráfico 2.3: Alterações da não-coalizão vs \% cadeiras da não-coalizão

— \% Alteração Não Coalizão $\quad$ \% Cadeiras Não Coalizão

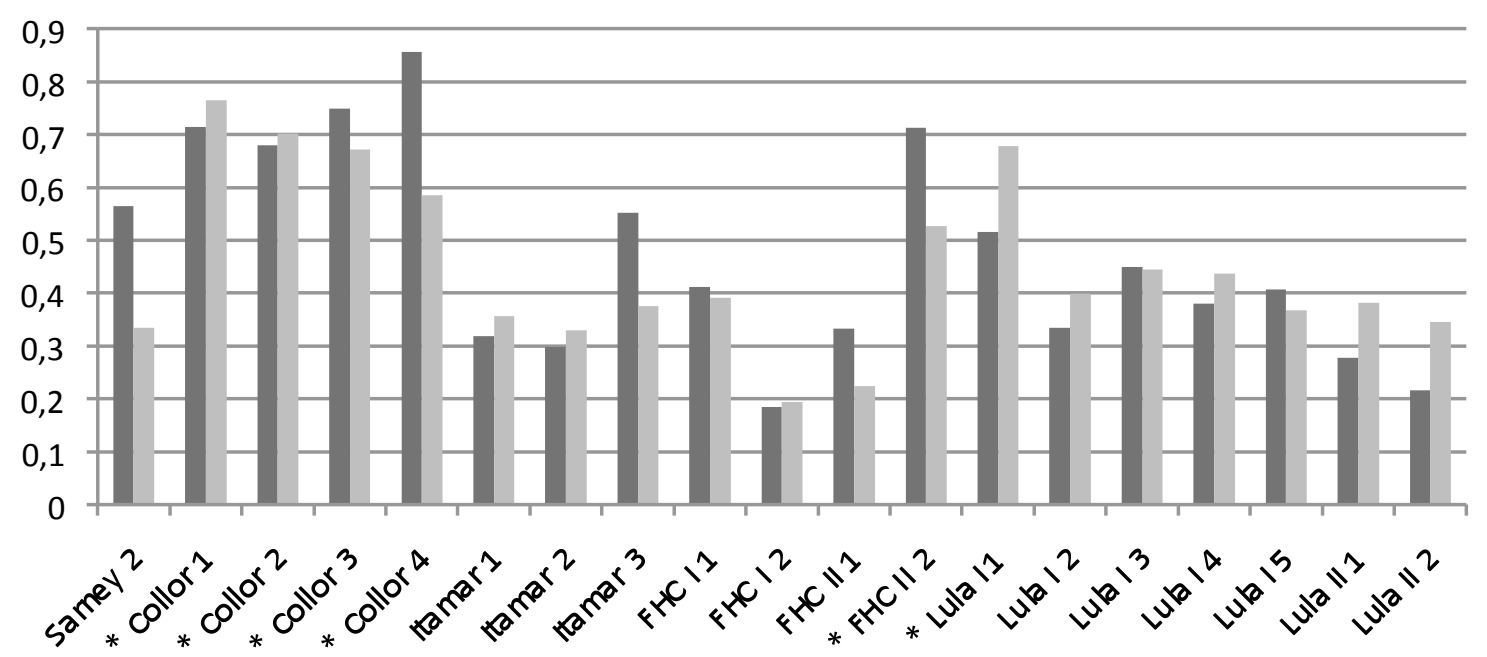

Fonte: Banco de Dados Legislativos, Cebrap.

Averiguaremos a seguir "quem", dentro da não-coalizão, está de fato participando desse processo. Por hora basta de dizer que se a não-coalizão, força oposta ao governo, em tese, participa aqui de forma expressiva, poderíamos tomar com extremamente inclusivo nosso modelo parlamentar. Dar vazão as diferenças é o que de 
melhor se poderia esperar dele. Em algum grau, os dados aqui observados dão indícios disso. No entanto, uma crítica pertinente ao os dados vem mostrando até aqui poderia relativizar substantivamente os a participaçao dos atores como foi descrita. Qual seja, a de que esta participação poderia estar ligada substancialmete a áreas de menor interesse, mesmo já tendo excluído da análise as projetos de “Homenagem”. Mas será que está possível crítica se sustentaria aos fatos? 


\section{3 Áreas temáticas}

Para classificar as leis aprovadas em áreas temáticas ${ }^{22}$, fiz uma análise da ementa das leis - quando necessário recorri aos pareceres dos relatores e textos das leis para proceder a análise. As matérias foram classificas então, segundo o impacto que as leis poderiam ter. Foram usados aqui todos os projetos aprovados no período, com exceção dos Projetos de Lei Orçamentária (PLN), pelos motivos antes exposto no capítulo 1. Em anexo (Anexo 2) seguem informações relativas aos critérios adotados bem como exemplos de leis para cada um dos casos.

O gráfico a seguir mostra a proporção de projetos de autoria da nãocoalizão e da coalizão, de 15/10/1988 áté 31/12/2010.

\footnotetext{
${ }^{22}$ Devo em muito a esse trabalho, ao empenho constante de Samir de Luna, que fez todo trabalho de classificação inicial dos projetos, com minúcia e perseverança surpreendentes. Foram longas semanas de análise árdua e dedicação para que esse trabalho viesse a luz.
} 
Gráfico 2.4: Autoria nas áreas temáticas

— Não-Coalizão — Coalizão

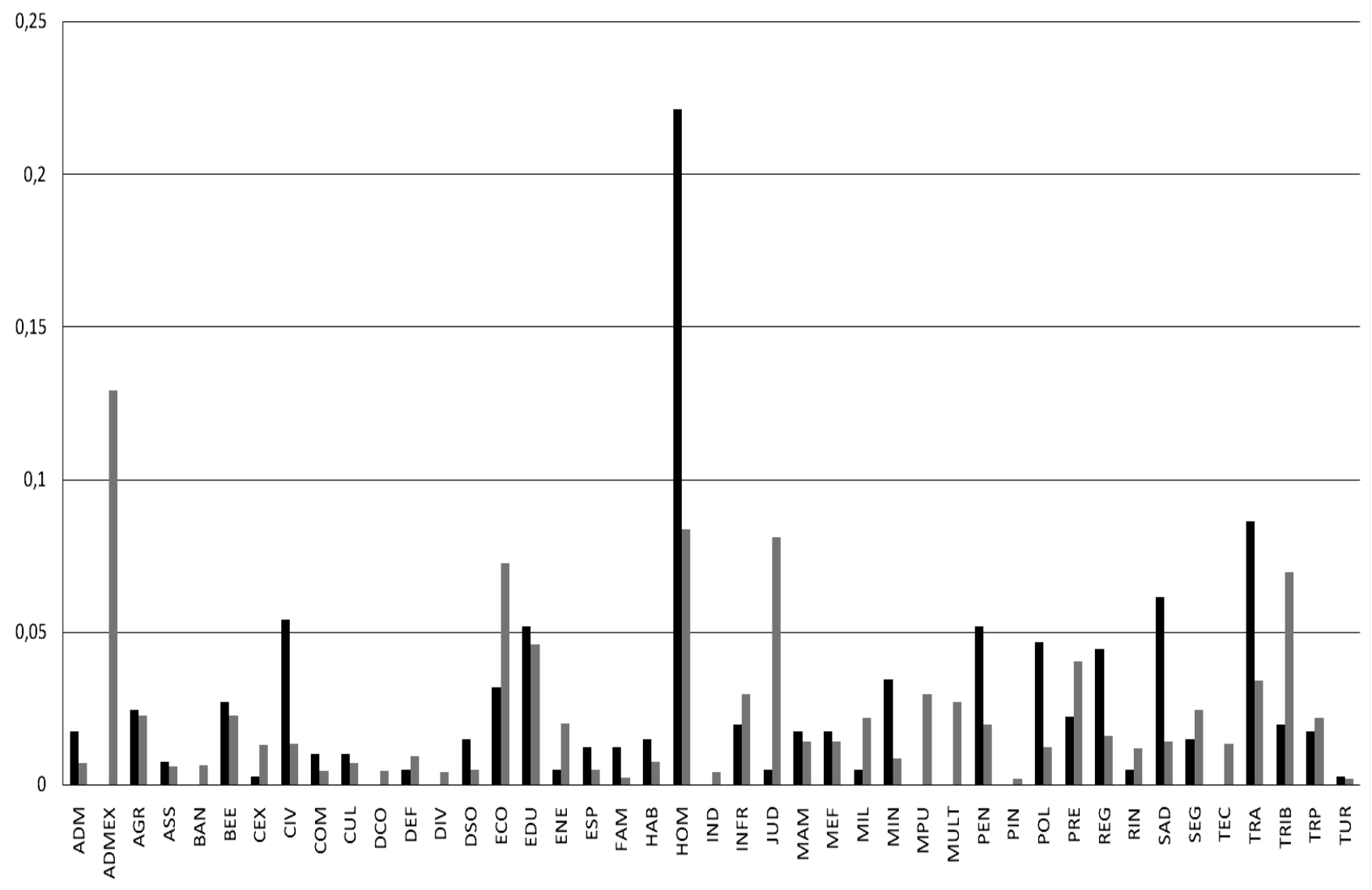

Fonte: Banco de Dados Legislativos, Cebrap.

Primeiramente, olhemos se existem diferenças substantivas em relação aos tipos de áreas de incidência dos projetos de autoria do governo e da não-coalizão. Pode-se notar aqui o porquê de havermos apartado da análise os projetos de "Homenagem". A não coalizão aprova mais projetos de homenagem do que a coalizão - como pode ser observado no gráfico acima.

Primeiro aqui vale uma resalva, podemos notar que ná área de iniciativa exclusiva do Presidente, a regulamentação administrativa doJudiciário, contamos ainda sim com projetos de autoria da não-coalizão. Aqui não se trata de equivoco 
na classificação, se não que estes projetos foram de fato apresentados por parlamentares que não compunham o governo ${ }^{23}$, raras exceções à regra.

Um fato interessante a ser notado é como a não-coalizão atua em áreas relacionadas aos diretos, acima do que o faz o governo. Notemos que regulamentações do código civil (CIV), educação (EDU), direitos sociais (DSO), defesa de minorias (MIN) e saúde (SAD) a participação da não-coalizão [e smeper maior. guardadas as proporções de cadeiras ocupadas.

Áreas de extrema importância para o governo, como as áreas tributária (TRIB) previdência (PRE) e economica (ECO) aparecem com destaque na atuação do governo. As possibilidades de análise que estes dados nos mostram, no entanto, vão além do nosso objetivo nesse trabalho. Vale destacar que o que aqui estamos testando é se, tendo visto que a não-coalizão participa, essa participação não poderia estar restrita a políticas de menor. Os dados falam por si só; essa não é um crítica pertinente a atuação da não-coalizão.

Mas será que isso volta a se repetir quando olhamos para as relatorias ocupadas pela não-coalizão? Vejamos a seguir.

Aqui levaremos em conta como, percentualmente, os projetos da nãocoalizão e do governo são divididos nas áreas temáticas. 0 denominador da divisão é o numero total de relatorias ocupadas por cada ator.

\footnotetext{
${ }^{23}$ Trata-se do PL.2938/92, que "Dispõe sobre o Estatuto da Advocacia e a Ordem dos Advogados do Brasil - OAB”, proposto pelo então deputado Ulysses Guimarães do PMDB na data de 22/6/1992, e do PL.4565/89, que "Altera a redação do art. 40 da Lei $n^{\circ} 7.244$, de 7 de novembro de 1984. determinando que o proprio juizo competente para o processo de conhecimento execute as decisões proferidas, de acordo com o disposto no inciso i do artigo 98 da Constituição Federal de 1988)" proposto na data de 8/6/1989, pelo então senador Mauricio Correa do PDT.
} 
Gráfico 2.5: Relatorias nas áreas temáticas

- Não-Coalizão n Coalizão

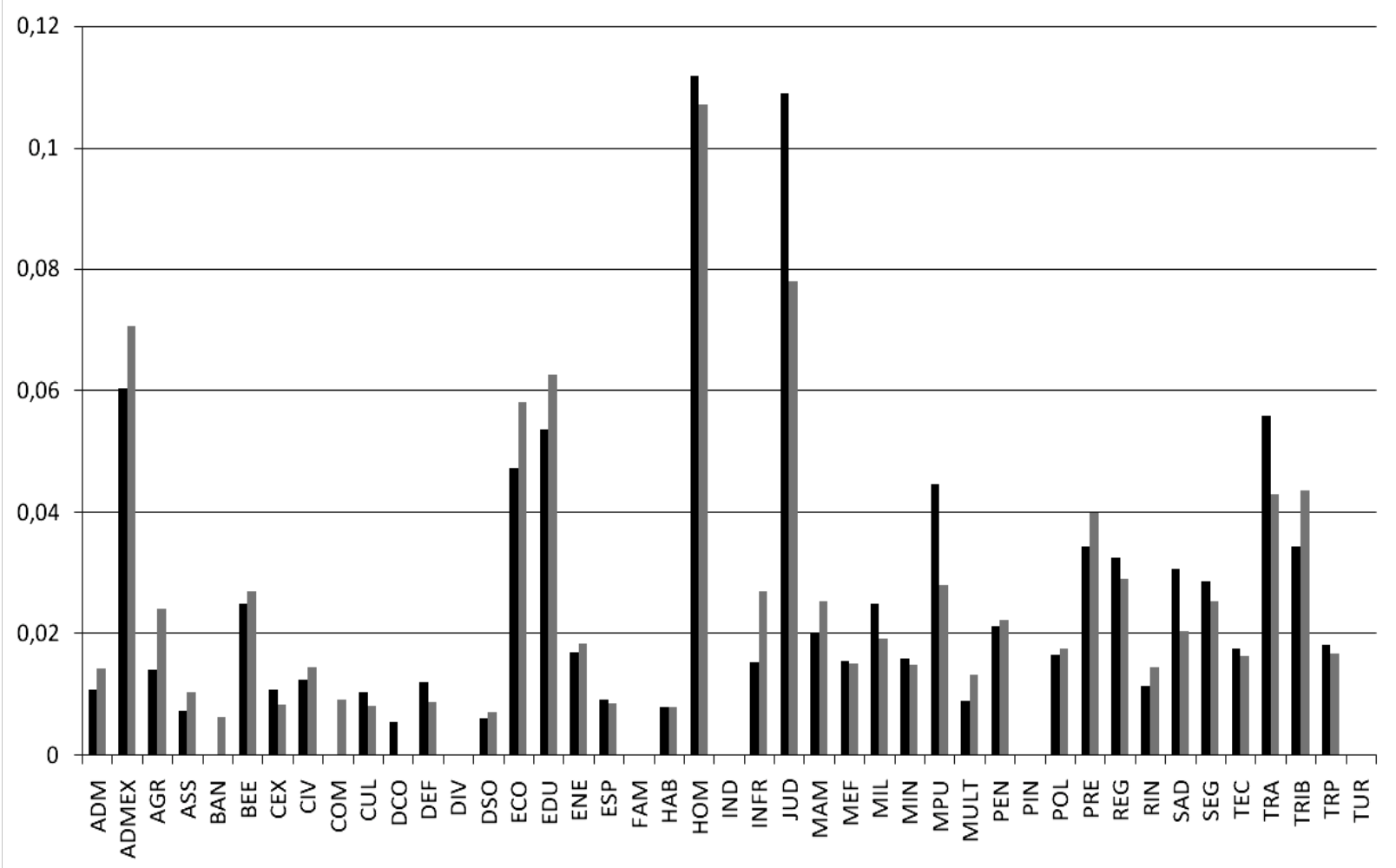

Fonte: Banco de Dados Legislativos, Cebrap.

Aqui não poderemos dizer que de forma geral não existem diferenças nas relatorias ocupadas pela não-coalizão quando comparada ao governo. No entanto cabe destacar que não-coalizão parece ter preferência em relatar matérias que versem sobre a regulamentação jurídica (JUD), haja vista como atuam também no sistema de análise e controle do Executivo (MPU). Esse evento não seria surpreendente não fosse o fato de nessas matérias estar aberta uma porta para crítica direta ao governo. Esses dados em algum grau reforçam por quais meios os partidos da não-coalizão podem fazer frente ao governo

Interessante notar como, de maneira substantiva, a não-coalizão relata matérias relacionadas ao mundo do trabalho. Mas não só aí, em todas as outras áreas citadas, 
inclusive atuando sobre as matérias de iniciativa privativa do Presidente da República, sua participação é substantiva.

Veremos agora se as tendências encontradas ao longo das análises precedentes se confirmam também quando se trata de alterar os projetos. E aqui vale lembrar que, se a relatoria é um importante cargo para direcionar os debates, esse fato se concretiza de forma factual quando a alteração proposta vem a compor o texto de lei aprovado, como mostra o gráfico abaixo.

Gráfico 2.6: Alterações nas áreas temáticas

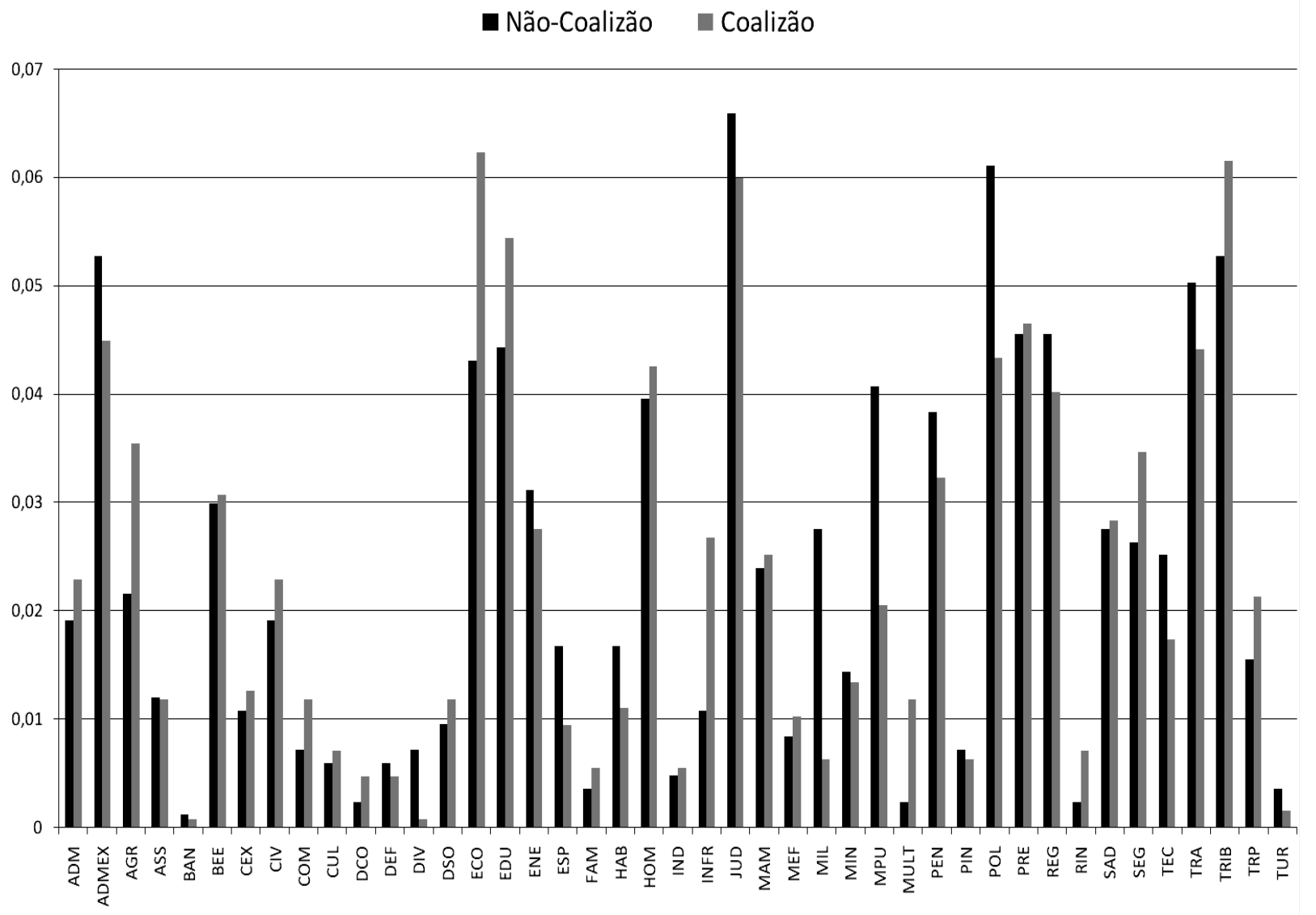

Fonte: Banco de Dados Legislativos, Cebrap. 
Como podemos notar as porcentagens de alterações por área temática confirmam que a participação dos atores ao longo do processo legislativo é consistente, não só quantitativamente - como foi visto anteriormente -, mas também qualitativamente.

Note-se que a não-coalizão dá atenção aos projetos de autoria privativa do Executivo (ADMEX). Se é o governo que define em grande parte a agenda legislativa, em virtude dos mecanismos institucionais que lhe garantem prerrogativa sobre áreas importantes da administração da máquina pública, podemos dizer que o controle de tudo que é proposto se dá em termos palpáveis pela não-coalizão. Veja que a não-coalizão participa ativamente alterando também as propostas do judiciário (JUD), Ministério Público (MPU), e mais, os temas que versam sobre as regras do jogo político (POL). Mesmo a regulamentação que diz respeito às Forças Armadas (MIL - militares) não fica à descoberto do controle da não-coalizão. Área de fundamental importância para os cofres públicos, a área tributária (TRIB) e previdenciária (PRE) merecem destaque dos partidos que não compõem a coalizão ministerial de governo. A parte disso, é notável que o governo tenha se empenhado em alterar propostas que dizem respeito a agricultura (AGR) economia (ECO), educação (EDU), segurança (SEG) e tributação (TRI) acima do que o fez a não-coalizão - mesmo que sua participação não tenha sido ínfima em quais quer dessas áreas.

Mas se até agora voltamos nosso foco para os atores que se encontram apartados do governo, sem fazer distinção entre aqueles que são usualmente chamados de oposição, no próximo capítulo trilharemos esse caminho. 


\section{Capítulo 3}

\section{Oposição e participação}

Como mostramos anteriormente, a participação positiva dos parlamentares que não pertencem a coalizão do governo se dá em todas as instâncias que avaliamos. No entanto quem de fato participa desse processo ainda ficou a descoberto, uma vez que mostramos apenas a atuação dos atores políticos em duas categorias, membros e não membros da coalizão.

Neste capítulo, nosso foco se voltará para a oposição formal ao governo, e não mais para a não-coalizão, simplesmente. Isto é, procurarei distinguir um grupo específico no interior dos não membros da coalizão. Os estudos que procuram averiguar como a oposição tende a atuar se dá largamente pelo viés negativo, através de vetos e obstruções (Inácio, 2007; Rabelo, 2009), ou mesmo estudos que se dedicaram a pensar de forma mais teórica a respeito das estruturas de acesso à contestação que podem e/ou deveriam estar abertas para a oposição no Brasil (Caggiano, 1995).

O trabalho de Inácio (2007) pode nos servir de exemplo de como estudos mais recentes passaram a enfatizar a necessidade de se compreender como se dão as convergências (na coordenação das alianças multipartidárias) sob governos de coalizão. Guiada pelo modelo partidário, a autora busca compreender o efeito de um artifício institucional cujo uso costuma ser creditado à oposição. Mais especificamente, analisa como a mudança do rito de tramitação das Medidas Provisórias afetou o uso estratégico da obstrução parlamentar na Câmara dos Deputados.

Seu argumento central é que o "trancamento da pauta de votações", ocasionado pela Emenda Constitucional $n^{\text {o } 32, ~ d e ~} 2001^{24}$, deu um poder extra às oposições, que

\footnotetext{
${ }^{24}$ Promulgada em 04 de setembro de 2001 e publicada no Diário Oficial da União no dia 12 de setembro do mesmo ano, EC 32 teve como principais alterações: o prazo para o decreto perder a eficácia passou a ser de 60 dias,
} 
passaram a obstruir as votações, provocando assim "barganhas seqüenciais" com o governo. O estudo analisa 580 votações nominais e 782 sessões deliberativas entre 2001 e 2006 e chega à conclusão que "a nova regulamentação do dispositivo modificou de forma importante o ambiente de operação da Coalizão de Governo e das oposições na arena legislativa" (Inácio, 2007, p. 30). É destacado pela autora que as coalizões partidárias "compostas por partidos que não ocupam posições contíguas no espectro ideológico podem resultar em situações mais complexas de barganha na medida em que os membros mais distantes podem apoiar propostas dos partidos da Oposição que lhes são próximos” (Inácio, 2007, p. 4).

$\mathrm{Na}$ medida em que os governos de coalizão necessitam de sua base de apoio para aprovar suas propostas, "as estratégias procedimentais das oposições na arena legislativa impactam os walk-away values ${ }^{25}$ dos partidos da coalizão por elevarem os custos de acomodação de seus interesses pelo governo" (Inácio, 2007, p. 7). Desta forma, tanto o contexto partidário como o regimental influiria diretamente nas possibilidades que a minoria, ou a não-coalizão formalmente minoritária, tem de se fazer ouvir. Como diz a autora, os partidos mais distantes ideologicamente impõem custos mais elevados de negociação e de barganha, dado que as suas preferências podem se situar além do que é considerado como razoável pelo partido formador da coalizão. Ou seja, a acomodação dos partidos dentro da base governista indica a necessidade de uma negociação mais ampla entre os membros da própria coalizão. A partir dessas

prorrogáveis por mais 60 . Entretanto, a partir do $45^{\circ}$ dia da edição, a MP passa a trancar a pauta do Plenário da casa onde estiver. Até que seja apreciada, nenhuma outra proposta de lei pode ser submetida à votação. A rejeição da MP em qualquer uma das duas casas impede que a proposta venha a ser reapresentada naquela legislatura. Além disso, a partir da EC 32, as MPs que não são apreciadas em 120 dias perdem a validade e não podem ser reeditadas novamente, como anteriormente.

25 "Walk-away value is what a negotiator, such a party leader, can gain without any new collective agreement, i. e., what he or she secures by walking away from the bargaining table". Lupia \& Strom, 2003, p. 10 apud Inácio. 2007. 
colocações pode-se notar que a falha na coordenação entre os atores da coalizão pode justificar e/ou abrir espaços para a atuação da oposição.

A autora indica uma associação entre a estratégia ${ }^{26}$ de proteção da coalizão e o uso de procedimentos regimentais para restringir as modificações e os vetos presidenciais:

"Essa 'cobertura política' é acionada quando os custos de transação de determinadas decisões legislativas podem ser elevados pelas estratégias das oposições parlamentares de forçar o posicionamento público dos parlamentares e instigar os eleitores contra eles" (p.7).

Inácio conjectura que, sob o novo rito de tramitação das MPs, as recompensas advindas da obstrução parlamentar se tornaram mais significativas, uma vez que com a elevanção dos custos de apreciação da MP todo o processamento da agenda legislativa subseqüente também é onerado. Nesse sentido, a autora entende que os trancamentos sucessivos podem trazer consigo "rodadas seqüenciais de barganhas para a liberação da pauta de votações” (Inácio, 2007, p. 22). Daí conclui que:

\footnotetext{
"A probabilidade de que as oposições utilizem o direito de obstruir as votações aumenta quando a pauta está trancada por MPs. O fato de que gabinetes desproporcionais aumentam as chances de obstrução das votações pelas oposições parece sinalizar para o uso estratégico desse direito com o objetivo de afetar a capacidade operativa da coalizão no plenário da Câmara dos Deputados. [...] o trancamento de pauta por MPs torna mais complexo o ambiente em que as barganhas legislativas ocorrem, pois potencializa as estratégias das oposições voltadas para provocar barganhas seqüenciais com a coalizão de governo" (Inácio, 2007, p. 31).
}

\footnotetext{
26 A autora utiliza a idéia de "proteção da coalizão", conforme definido primeiramente por Huber (1996), para indicar a mobilização feita por parte da coalizão governamental na tentativa de evitar que membros dessa própria coalizão migrem para oposição, tornando assim mais custoso o apoio à agenda de governo.
} 
No que tange a este estudo, a discussão feita por Inácio é válida na medida em que a obstrução parlamentar acaba por se configurar como umas das ferramentas que a oposição tem a seu favor. Este recurso quando coadunado com as características gerais das composições partidárias pode representar um precioso artifício nas mãos da nãocoalizão, alterando sua capacidade de ação e servindo como um importante instrumento de pressão.

Como vemos, costuma-se tratar a posição ocupada pela oposição através do viés que enfatiza a conduta da coalizão. A oposição serve aqui para explicar como a mudança da regra influi no comportamento dos parlamentares daquelas legendas que formam a coalizão de governo e tem papel secundário na análise. Desta forma, a capacidade que a oposição teria de vetar a tramitação de matérias serve para demonstrar o problema de coordenação de interesses dentro da coalizão de governo. Ou seja, o problema seria a falta de coordenação da maioria numérica situada nos partidos da coalizão de governo.

Binder (1997) faz um levantamento das mudanças que foram sendo feitas ao longo do tempo no ordenamento dos direitos parlamentares das minorias no Senado e da Câmara dos Deputados norte-americanos. A autora coloca em questão as estratégias e objetivos levados em conta pelos partidos quando redefinem as regras norteadoras dos trabalhos legislativos.

Para introduzir o tema, Binder assinala que a maioria conta com sua superioridade numérica para alcançar resultados favoráveis, ao passo que a minoria conta com o auxílio das regras procedimentais para emendar, atrasar, ou obstruir a agenda da maioria. Ela indica que, na prática, a evolução dos direitos das minorias congressuais sugere um caminho diferente daquele que apregoa uma participação igual de todos os membros, argumentando que "far from enjoying iron-clad protection, minority rights are in fact conditional on the shape of partisan forces within the instituion" (Binder 
1997: 2). Por isso os resultados das políticas dependem do conjunto de regras sob as quais se dá a competição de cada proposta legislativa formulada e posteriormente considerada.

As possibilidades de atuação da oposição são limitadas pelas regras do jogo. Contudo, ainda assim, tais regras concedem à minoria a oportunidade de participar do processo em mais de uma instância do Congresso. Focando unicamente na autoria dos projetos com vistas à identificar a autoria das leis aprovadas acaba por deixar de lado uma parte importante do processo legislativo. Os dados analisados até o momento mostraram a preponderância do governo nas chances de pautar os temas que entram em debate, mas mostraram também que a não-coalizão também participa desse processo. Cabe investigar, portanto,se a participação destes dois grupos se dá da mesma forma ou se através de mecanismos distintos. É possível que a análise da participação efetiva dos atores ao longo da tramitação das matérias, seja ocupando cargos de destaque ou efetuando alterações que lhes permitam formatar o modo como as leis vêm à luz evidenciem resultados inesperados. Dito de outro modo: o binômio aprovação/reprovação indicado nos índices de dominância e sucesso ${ }^{27}$ do Executivo para se compreender como se processa a representação dentro do Congresso poderia ser insuficiente no esclarecimento das questões colocadas nesta pesquisa. Seria necessário transcendê-lo para comprovar a tese de que a oposição está excluída do processo legislativo, que só lhe resta tentar obstruir ou derrotar o governo.

Para prosseguir na análise, cabe aqui então distinguir de forma cabal aqueles partidos que estando alijados da coalizão ministerial fazem de fato oposição ao governo, com a proposta de avaliar suas capacidades de participação positiva deste grupo.

\footnotetext{
${ }^{27}$ Ver nota 7.
} 
Usualmente se entende que o papel principal da oposição consiste em questionar o governo e responsabilizá-lo por seus atos frente ao eleitorado, dado que poucas vezes dispõem da quantidade suficiente de votos para atuar de forma propositiva.

Apesar de, na maior parte das vezes, serem usadas de forma similar, os termos "oposição" e "minoria" não devem ser entendidas como sinônimos, já que encontrar-se fora do governo, como dito anteriormente, nem sempre é fazer oposição ao mesmo. A confusão entre esses dois termos não é descabida, haja visto que nosso parâmetro de comparação, no que diz respeito a avaliação de nosso sistema político, esteve sempre balizado pelo modelo parlamentarista clássico de Westminster. Nesse sistema é a maioria parlamentar que indica o primeiro ministro, que se tornará o chefe do governo. No entanto, a perda da maioria legislativa pode acarretar na queda do chefe de governo, via o chamado voto de confiança. Assim, o grupo parlamentar minoritário encontra-se na oposição, que apesar de ter pouco espaço para participar da formatação das políticas do governo, tem chances reais de vir a ocupar o poder após uma reorganização da maioria no interior do parlamento. Nesse sistema torna-se coerente identificar a não coalizão com a oposição já que, por tratar-se de um sistema bipartidário, sempre um dos partidos se encontra alijado do governo, esperando uma oportunidade para ocupar o Executivo.

No sistema presidencialista, a perda da maioria parlamentar por parte do Presidente pode fazer do governo inoperante e fraco, mas não justifica sua queda. $O$ governo pode ser minoritário e mesmo assim ter garantido os poderes de agenda com que o Presidente é dotado - como ficou evidente na autoria dos projetos (Cap. 1).

Segundo, Giampaolo Zuchini (1986), é através da análise dos papéis e das relações segundo os quais os atores operam, que podemos delimitar quando um ator "A" adota uma posição igual e contrária a de um ator "B". Se dentro de uma relação 
política podemos identificar a oposição como aquele grupo de pessoas ou indivíduos que objetivam fins contrastantes com os identificados pelo grupo ou grupos detentores do poder, este último é reconhecido institucionalmente na figura das autoridades políticas econômicas ou sociais que o compõe. No que tange ao sistema político, existem basicamente dois tipos de oposição; aquele que faz uso de métodos e meios constitucionais e lícitos, e aquele que opera por outros métodos e meios ilegais. Aqui irá importar somente o primeiro tipo, uma vez o objetivo que proposto é entender como isso acontece dentro do Congresso brasileiro.

Chamadas de legitimas, as Oposições que operam dentro do sistema atuam dentro dos valores e limites claramente partilhados pela sociedade, na qual o conflito é aceito e institucionalizado. Dentro do contexto parlamentar, a oposição pode agir de forma negativa - tentando obstruir ou barrar o processo legislativo - ou de forma positiva, através da formulação de repostas alternativas as propostas pelo(s) grupo(s) detentor(es) do poder. Vale notar que ambas estratégias não são excludentes. Assim, um ator que se encontra na oposição pode tentar barrar as propostas que lhe são contrárias ao mesmo tempo que propõem soluções alternativas ao tema em debate. É dizer, atuando positivamente dentro do sistema. O que difere ambos os grupos é se estas propostas serão aceitas e/ou incorporadas ou não.

São conhecidos e ressaltadas na literatura os meios usados pela oposição para obstruir e tentar negar ao governo a possibilidade de aprovar os projetos a que se opõe (Rabelo Santos, 2009; Inácio, 2007). Menos notadas e mesmo desconsideradas são as formas pelas quais a oposição consegue influenciar as decisões efetivas do governo.

Se formalmente sabemos que as regras garantem os direitos das minorias atuarem na formatação da legislação, haja visto, por exemplo que sua participação é 
garantida constitucionalmente nas comissões $^{28}$, coisa que assinalamos no capítulo anterior, na prática ainda não sabemos se isso se concretiza de forma prática quando o foco é a oposição.

Uma operacionalização de que partidos de fato formam a oposição poderia ser obtida a partir do grau de disciplina que esses partidos demonstram em relação à indicação de voto do líder do governo nas votações nominais do período. Assim, partidos com maior grau de convergência com a indicação de voto do governo seriam diferenciados daqueles que na maior parte das votações se posicionam no flanco oposto, fazendo oposição ao governo. No entanto esse indicador se mostraria incongruente com o grau de participação aqui verificado por esses atores. Senão vejamos.

Ao olharmos para a disciplina dos partidos que se encontram fora da coalizão, no entanto, notaremos que uma parte considerável deles, mesmo sem ter cargos no governo, ou seja, que não se encontrarem formalmente dentro da coalizão ministerial, de fato dão apoio substantivo as propostas do governo e são altamente disciplinados em relação ao governo. Por vezes suas taxas de disciplina em relação a indicação de voto do líder do governo são até mais altas que partidos que participam da coalizão. Para dar dois exemplos, em dois governos recentes, na primeiro coalizão de Fernando Henrique Cardoso, partidos como PSL, PP, PDS ou PL, tinham taxas de disciplina acima do PMDB, que compunha a coalizão de governo. Na primeira coalizão de Lula, o fato volta a se repetir, e partidos como PMN, PSL, PSC ou PMDB, mesmos estando fora da coalizão tiveram disciplina maior que o PTB, PDT ou PV, membros formalmente

\footnotetext{
28 Segundo o regimento interno da Câmara, na "Na constituição das Comissões assegurar-se-á, tanto quanto possível, a representação proporcional dos Partidos e dos Blocos Parlamentares que participem da Casa, incluindo-se sempre um membro da Minoria, ainda que pela proporcionalidade não lhe caiba lugar." (Art. 23, RIDC). Na composição da Mesa também "É assegurada a participação de um membro da Minoria, ainda que pela proporcionalidade não lhe caiba lugar." (Art. 9o, § 3 으, RICD).
} 
participantes da coalizão. Isso não se dá apenas nas duas coalizões de governo citadas, se repete ao longo de todas as coalizões que analisamos.

Esses partidos que foram classificados por Freitas (2009) como partidos satélites, pelo fato de orbitarem em torno do Poder Executivo, dando-lhe apoio, no mais das vezes, independente de sua participação no governo, podem ser, então, melhor nomeados: são membros da coalizão legislativa sem serem membros da coalizão governamental.

Se queremos averiguar em medida nosso sistema legislativo é inclusivo, devemos procurar entender quais são os partidos responsáveis pela expressiva participação da não coalizão como foi mostrado em seções anteriores. São eles apenas "os satélites", os membros de uma eventual coalizão legislativa? Ou todos os partidos acabam por, de uma forma ou de outra, participar do processo legislativo? A questão portanto está em saber se é possível distinguir no interior da não-coalizão, quais são os partidos que fariam parte da oposição e quais fariam parte da base de apoio legislativa do governo. Caso o sistema dê vazão também a participação dos partidos normalmente classificados como oposicionistas, poderíamos dizer que temos um indicativo de que nosso sistema teria um caráter bem mais inclusivo do que normalmente se supõe, a ponto de poder retomar o uso do termo "consociativo" para classificá-lo.

Nesse sentido as votações nominais que se deram no período podem nos servir para averiguar o grau de conflito entre os partidos - já que sabemos que a maioria dos temas não são votados nominalmente. E claro, como as votações selecionadas para a análise dizem respeito somente aos temas onde o grau de conflito teve maior intensidade, tão pouco espera-se que englobem todos os temas.

As votações nominais que se deram no período servem para averiguar o grau de conflito entre os partidos. Como se sabe a maioria dos temas não são votados 
nominalmente, isto é, tendem a ir a votação nominal apenas as matérias mais importantes e controversas. Ainda assim, dado os preceitos constitucionais e regimentais que obrigam votação nominal em determinadas matérias, como por exemplo, matérias constitucionais, temos que grande parte do vai a votação nominal é decidido por unanimidade ${ }^{29}$. Esta alta incidência de matérias unânimes tende a ser simplesmente descartada pelos analistas. Contudo, deve se notar que o simples fato que, em um número grande de matérias, todos parlamentares votam de maneira similar, não pode ser tomado como se fosse ditado pela natureza das próprias matérias, que estas fossem destituídas per se de sentido conflitivo. O grau de conflito político é gerado endogenamente. Se uma matéria é ou não conflitiva é resultado do processo político. Ao menos, deve se conceder que a oposição não politiza todas as questões e que não busca paralisar a atividade legislativa em todas as matérias. Há portanto um grau de consenso básico que permeia e dá fundamentação ao sistema que não pode ser ignorado.

O gráfico abaixo mostra que parte substantiva de tudo que foi a votação nominal no período pós-Constituinte (até o final de 2010) foi decidido por unanimidade ${ }^{30}$.

\footnotetext{
${ }^{29}$ Tomamos como unânimes as votações nas quais mais de $90 \%$ dos votos tem o mesmo destino; "sim" ou "não".

${ }^{30} \mathrm{O}$ cálculo exclui as votações que não alcançaram quorum.
} 
Gráfico 3.1: Votações Unânimes

não Unânimes

Unânimes

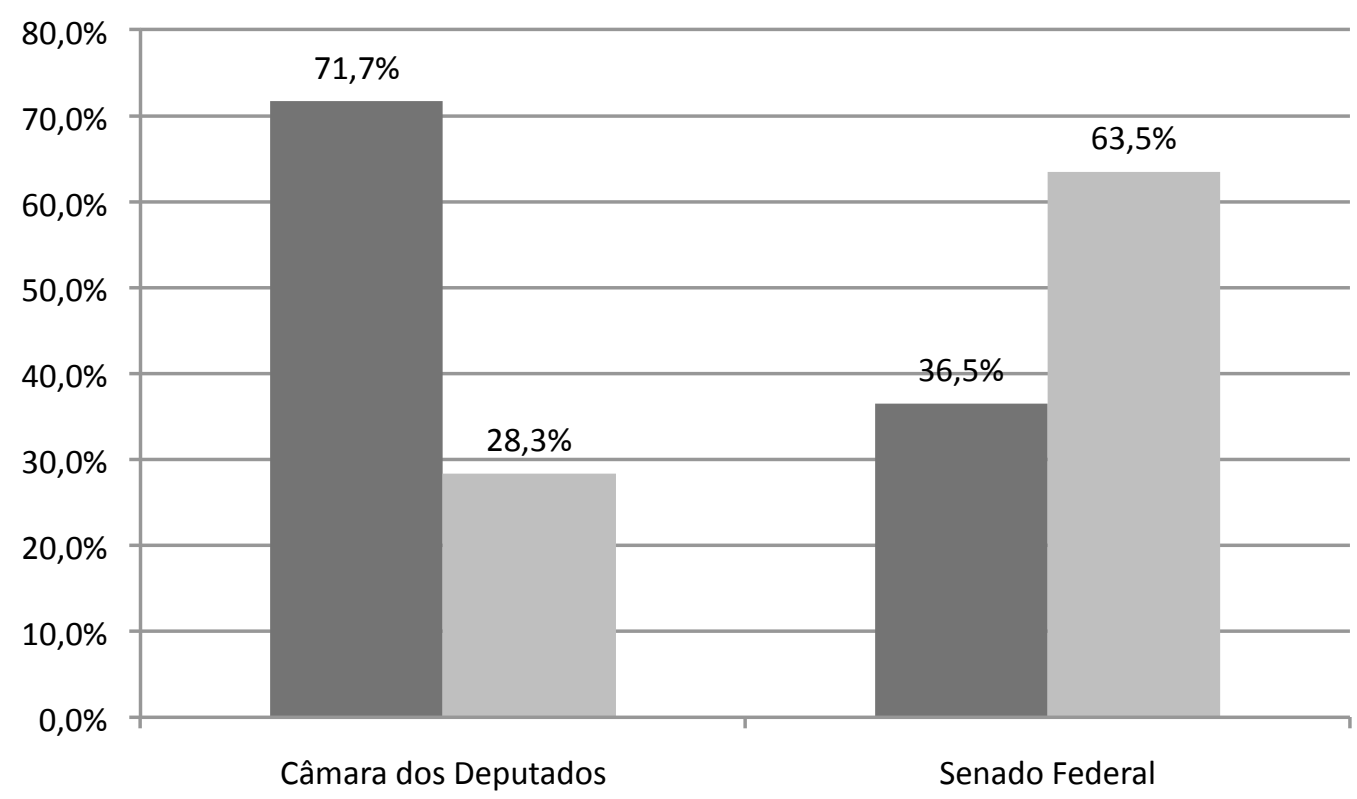

Fonte: Banco de Dados Legislativos, Cebrap.

Chega a ser destoante como no Senado Federal a unanimidade prevalece se comparado à Câmara. Mas isso tão pouco causa espanto uma vez que o número de atores ali é bem menor, logo, maior a facilidade para se chegar a um consenso. De outro modo, como o Senado costuma ser a casa revisadora, é esperado que os projetos cheguem ali já tendo sido alvo debates mais aprofundados.

Passando a análise das votações nominais em que há conflito, podemos notar que mesmo quando o governo é majoritário, quando poderíamos contar com apoio formal de uma maioria, o governo nem sempre vence as votações contando exclusivamente com sua base formal de apoio. 
Tabela 3.1: Coalizão vence com as próprias forças?

\begin{tabular}{|c|c|c|}
\hline \multicolumn{2}{|c|}{ Câmara dos Deputados } \\
\hline & Governo Majoritário & Governo Minoritário \\
\hline $\begin{array}{c}\text { Vence com a } \\
\text { Coalizão }\end{array}$ & $535(62,3 \%)$ & $33(21,9 \%)$ \\
\hline $\begin{array}{c}\text { Necessita da Não } \\
\text { Coalizão }\end{array}$ & $324(37,7 \%)$ & $118(78,1 \%)$ \\
\hline Total & $859(100 \%)$ & $151(100 \%)$ \\
\hline
\end{tabular}

\begin{tabular}{|c|c|c|}
\hline \multicolumn{2}{|c|}{ Senado Federal } \\
\hline & Governo Majoritário & Governo Minoritário \\
\hline $\begin{array}{c}\text { Vence com a } \\
\text { Coalizão }\end{array}$ & $247(71,6 \%)$ & $1(1,5 \%)$ \\
\hline $\begin{array}{c}\text { Necessita da Não } \\
\text { Coalizão }\end{array}$ & $98(28,4 \%)$ & $65(98,5 \%)$ \\
\hline Total & $345(100 \%)$ & $66(100 \%)$ \\
\hline
\end{tabular}

Fonte: Banco de Dados Legislativos, Cebrap.

Um leitor atento se perguntaria como é possível mesmo quando o governo é minoritário vencer apenas contando com suas próprias forças, sem o auxílio da não coalizão. A resposta é simples, muitas das votações consideradas exigiam quorum simples, isto é, a maioria dos presentes. Logo é possível que em governos minoritários que o governo vença sem necessitar contar com o apoio da não coalizão em virtude das faltas dos não membros da coalizão ou oposição. Basta contar com a maioria dos presentes. 
Novamente notamos aqui que as coisas são muito diferentes quando comparamos a Câmara ao Senado. Mas devemos lembrar aqui também, que as votações nominais, nos servem apenas para medir o grau de conflito entre os atores.

Se nos detivermos agora nos resultados obtidos nessa tabela poderemos notar que no Senado Federal o grau de conflito é menor, quando se trata de governo minoritários. Razão pelo qual somente em um caso a coalizão ter necessitado do apoio da não coalizão para vencer uma votação. Pode-se conjecturar que isto se deva a menor presença dos pequenos partidos no Senado.

Quando tratamos dos governos majoritários no Senado, podemos notar que há apoio efetivo da não coalizão ao governo em $28.4 \%$ das votações. Olhando para o grau de conflito que teve lugar na Câmara, notaremos que a não coalizão dá apoio ao governo em $37.7 \%$ das votações. Já nos governos minoritários o apoio se dá na ordem de $21.9 \%$ das votações.

Visto por outro ângulo, poderíamos formular a hipótese de que sendo o sistema conflituoso, era de se esperar um volume de votações nominais muito maior do que de fato se tem. Para se ter uma idéia, diversas votações de pareceres de comissão e plenário têm lugar todas semanas nas casas legislativas. Mesmo assim, em todo período analisado apenas 1421 votações nominais foram feitas nas duas casas legislativas. Se pararmos pra pensar, é um número bem pequeno para um período tão grande, o que indica por si só que o grau de conflito não é tão alto assim. Logo, não haveria motivos para estranhar o fato dos Poderes se completarem, motivo pela qual a coalizão legislativa é sempre maior que o governo.

As tabelas que se seguem abrem as informações relativas à participação dos diferentes partidos que não fazem parte das coalizões governamentais ao longo do período considerado. A primeira coluna identifica o partido não membro em cada uma 
das coalizões formadas pelos diferentes presidentes seguindo-se o critério proposto por Figueiredo (2007). A segunda coluna reporta a porcentagem média de votos em acordo com o líder do governo dados pelos membros daquele partido. Em outras palavras, estes partidos são tratados como se pertencessem à coalizão e a sua disciplina em relação ao governo é testada. Nestes termos, o que se afere é a medida cada um dos partidos que se encontraram fora da coalizão se aproximaram ou se distanciam do governo nas votações nominais período ${ }^{31}$.

$\mathrm{Na}$ terceira coluna temos a proporção de cadeiras ocupadas pelos partidos. Notese que só foram incluídos os partidos que não fazem parte da coalizão de governo. $\mathrm{O}$ valor reportado é uma média da proporção de cadeiras controladas pelo partido no período considerado. ${ }^{32}$ A terceira, quarta e quinta coluna mostram a proporção de participação dos partidos nas relatorias válidas, alterações aprovadas e por fim na autoria de projetos.

Notaremos que não há relação direta entre participação e disciplina. Os partidos que participam efetivamente do processo não são necessariamente os partidos mais disciplinados em relação ao governo. Mesmo que os maiores partidos, de oposição ao governo ou não ${ }^{33}$, tenham um pouco mais espaço para participação, notaremos que os pequenos igualmente participam do processo. Aqui optamos por trabalhar apenas com os governos FHC e Lula, governos que deixam de lados opostos dois dos partidos brasileiros mais relevantes (PT e PSDB), e em situações inversas, ora participando do governo, ora na oposição. As tabelas com outras coalizões do período encontram-se no Anexo 3.

\footnotetext{
${ }^{31} \mathrm{O}$ valor de $100 \%$ indica a convergência máxima, e zero nenhuma. Aqui vale tomar nota de que se um partido não votou em nenhum dos pleitos sua disciplina também é indicada como nula ( $0 \%$ ), da mesma forma que se apenas participou de uma das votações nominais e seu voto foi convergente com o do líder do governo, sua disciplina é de $100 \%$.

${ }_{32}^{32}$ Média para controlar os efeitos que a migração partidária.

${ }^{33}$ Como procedi desde o começo do trabalho não levei em conta nesse cálculo a participação dos parlamentares sem partido. Mas vale dizer que o número de cadeiras que ocupam e a participação que detém ao longo do processo é praticamente nula.
} 
Tabela 3.2: Geral FHC I

\begin{tabular}{|c|c|c|c|c|c|c|c|c|c|c|c|}
\hline \multicolumn{6}{|c|}{ FHCI1 } & \multicolumn{6}{|c|}{ FHC 12} \\
\hline Partido & Disc_Gov & Tam & Relat & Alter & Autor & Partido & Disc_Gov & Tam & Relat & Alter & Autor \\
\hline PSL & 93,0 & $1,1 \%$ & $1,4 \%$ & $1,0 \%$ & - & PSC & 100,0 & $0,2 \%$ & - & $0,4 \%$ & - \\
\hline PSC & 87,7 & $0,2 \%$ & $0,2 \%$ & - & - & PSL & 94,7 & $0,7 \%$ & $0,4 \%$ & $0,9 \%$ & - \\
\hline PSD & 86,5 & $0,8 \%$ & $0,5 \%$ & - & - & PRONA & 91,1 & - & - & - & - \\
\hline PRP & 86,4 & $0,2 \%$ & - & $1,0 \%$ & - & PSD & 87,5 & - & - & - & - \\
\hline PP_2 & 82,9 & $6,2 \%$ & $2,5 \%$ & $3,1 \%$ & $6,9 \%$ & PMN & 81,9 & - & - & - & - \\
\hline PL/PR & 82,8 & $1,6 \%$ & $1,6 \%$ & - & - & $\mathrm{PL} / \mathrm{PR}$ & 73,9 & $1,9 \%$ & $0,4 \%$ & $0,4 \%$ & - \\
\hline PDS/PP & 82,3 & $13,3 \%$ & $9,2 \%$ & $17,5 \%$ & $7,9 \%$ & PV & 32,4 & - & - & - & - \\
\hline PMN & 37,2 & $0,9 \%$ & $1,8 \%$ & $1,0 \%$ & - & PCB/PPS & 30,6 & $1,2 \%$ & $0,5 \%$ & $0,4 \%$ & - \\
\hline PV & 35,1 & $0,2 \%$ & $0,2 \%$ & - & - & PDT & 23,8 & $4,7 \%$ & $2,2 \%$ & $3,1 \%$ & $3,3 \%$ \\
\hline PCB/PPS & 26,7 & $1,1 \%$ & $1,4 \%$ & $1,0 \%$ & $1,0 \%$ & PSB & 23,3 & $2,5 \%$ & $7,8 \%$ & $3,1 \%$ & $1,1 \%$ \\
\hline PSB & 25,1 & $2,5 \%$ & $5,3 \%$ & $3,1 \%$ & $2,0 \%$ & PCdoB & 20,8 & $1,8 \%$ & $0,6 \%$ & $2,2 \%$ & $2,2 \%$ \\
\hline PDT & 20,8 & $4,8 \%$ & $4,1 \%$ & $5,2 \%$ & - & PT & 19,0 & $9,1 \%$ & $6,0 \%$ & $12,3 \%$ & - \\
\hline PT & 10,9 & $8,9 \%$ & $7,1 \%$ & $13,4 \%$ & $12,9 \%$ & PSTU & 18,1 & - & - & - & - \\
\hline PCdoB & 8,3 & $1,9 \%$ & $0,5 \%$ & - & - & & & & & & \\
\hline $\mathrm{PJ} / \mathrm{PTC}$ & 0,0 & - & - & - & - & & & & & & \\
\hline PRONA & 0,0 & - & - & - & - & & & & & & \\
\hline PRS & 0,0 & - & - & - & - & & & & & & \\
\hline
\end{tabular}

Fonte: Banco de Dados Legislativos, Cebrap.

Como poderemos notar, a primeira coalizão do primeiro governo de FHC (FHC I1) conta com uma ampla participação de quase todos os parlamentares que estão situados fora da coalizão ministerial. Nas matérias que relatam esse fato fica patente. $\mathrm{O}$ dado mais notável que essa tabela nos apresenta é a participação do PT que não só altera os projetos proporcionalmente acima de seu tamanho, como também pauta $12.9 \%$ da agenda (autor). Não menos digno de nota, é o fato de vários partidos baixo grau de atrito com o governo participarem também do processo. O destaque vai para o PP_2 e PDS/PP participando pautando a agenda da época. No entanto, quando o assunto é participação nas matérias relatadas podemos notar, guardadas as proporções, um alto grau de atividade dos partidos que usualmente são tidos como opositores dessa coalizão. O PT, partido de oposição clássico à essa coalizão, pauta a agenda ainda acima do que se poderia pensar, seja na primeira ou na segunda coalizão tucana $(12.9 \%$ e $12.3 \%)$.

A lógica se mantém a mesma para as próximas duas coalizões, mas o destaque vai para "FHC II 2". Mais especificamente para o PFL/DEM. Note-se que mesmo 
fazendo parte de todas as coalizões anteriores do governo FHC, esse partido mesmo a após a saída do governo se mantém extremamente alinhado à coalizão. Esse dado pode ser aferido se olharmos para a sua disciplina partidária. Mas o que chama mais a atenção é como este partido continua participando acima de seu tamanho nas relatorias e alterações. A esse partido aprece caber bem o rótulo de satélite, pois mesmo apartado da coalizão aprece agir e participar da mesma.

Tabela 3.3: Geral FHC II

\begin{tabular}{|c|c|c|c|c|c|c|c|c|c|c|c|}
\hline \multicolumn{6}{|c|}{ FHC II1 } & \multicolumn{6}{|c|}{ FHC II 2} \\
\hline Partido & Disc_Gov & Tam & Relat & Alter & Autor & \begin{tabular}{|l|} 
Partido \\
\end{tabular} & Disc_Gov & Tam & Relat & Alter & Autor \\
\hline PRONA & 100,0 & - & - & - & - & PHS & 100,0 & - & - & - & - \\
\hline PSC & 92,0 & - & - & - & - & PFL/DEM & 88,6 & $19,7 \%$ & $25,7 \%$ & $26,8 \%$ & - \\
\hline PHS & 89,9 & - & - & - & - & PST & 85,9 & - & - & - & - \\
\hline PTB & 85,8 & $5,2 \%$ & $3,6 \%$ & $2,0 \%$ & $1,0 \%$ & $\mathrm{PL} / \mathrm{PR}$ & 80,4 & $4,3 \%$ & $0,4 \%$ & - & $1,7 \%$ \\
\hline PTN & 79,0 & - & - & - & - & PCB/PPS & 79,6 & - & - & - & - \\
\hline PL/PR & 66,1 & $3,1 \%$ & $0,7 \%$ & $0,8 \%$ & $0,5 \%$ & PTB & 78,7 & $6,8 \%$ & $1,8 \%$ & $1,8 \%$ & - \\
\hline PSD & 60,0 & - & - & - & - & PSL & 75,0 & - & - & - & - \\
\hline PSL & 58,7 & $1,0 \%$ & $0,2 \%$ & - & - & PT & 68,4 & $11,3 \%$ & $9,7 \%$ & $10,7 \%$ & - \\
\hline PCB/PPS & 49,5 & $2,6 \%$ & $1,8 \%$ & $1,6 \%$ & $0,5 \%$ & PSDC & 50,0 & - & - & - & - \\
\hline PV & 48,8 & $0,2 \%$ & $0,5 \%$ & - & $0,5 \%$ & PCdoB & 48,4 & $1,9 \%$ & $0,9 \%$ & $3,6 \%$ & - \\
\hline PSB & 38,4 & $2,9 \%$ & $1,9 \%$ & $2,8 \%$ & $2,1 \%$ & PDT & 47,3 & $3,6 \%$ & $4,4 \%$ & $8,9 \%$ & - \\
\hline PT & 38,1 & $10,9 \%$ & $11,0 \%$ & $13,4 \%$ & $9,8 \%$ & PSB & 46,0 & $3,8 \%$ & $0,9 \%$ & $3,6 \%$ & - \\
\hline PDT & 37,7 & $4,0 \%$ & $5,4 \%$ & $9,1 \%$ & $3,1 \%$ & PTN & 38,5 & - & - & - & - \\
\hline PCdoB & 36,9 & $1,5 \%$ & $0,9 \%$ & $3,2 \%$ & $3,1 \%$ & & & & & & \\
\hline PSTU & 27,8 & - & - & - & - & & & & & & \\
\hline PSDC & 21,1 & - & - & - & - & & & & & & \\
\hline
\end{tabular}

Fonte: Banco de Dados Legislativos, Cebrap.

Outra coisa que pode ser assinalada é que ao final do segundo governo de FHC, a abertura para a participação na definição da agenda (ver coluna relativa à autoria) parece ter sido absolutamente vetada aos partidos que não compunham a coalizão ministerial de governo. Talvez aqui pese o calendário eleitoral. Mas a participação nas relatorias e na proposição de alterações acatadas continua proporcionalmente significativa em relação ao tamanho dos partidos. Destaca-se aqui a alta participação do PFL, que acabava de deixar o governo, estando, por nosso critério, fora da coalizão, 
portanto, ainda que seja difícil tratá-lo como oposição. Interessante agora observar como esse mesmo processo se deu no governo de seu oponente direto, o PT.

Tabela 3.4: Geral Lula I (1)

\begin{tabular}{c|c|c|c|c|c|c|c|c|c|c|c|}
\multicolumn{9}{|c|}{ Lula I I } & \multicolumn{1}{c|}{ Lula I 2 } \\
\hline Partido & Disc_Gov & Tam & Relat & Alter & Autor & Partido & Disc_Gov & Tam & Relat & Alter & Autor \\
\hline PMN & 100,0 & $0,2 \%$ & - & - & $0,9 \%$ & PSL & 100,0 & - & - & - & - \\
\hline PST & 100,0 & - & - & - & - & PSC & 96,6 & $1,2 \%$ & $0,2 \%$ & $1,5 \%$ & - \\
\hline PSL & 96,5 & - & - & - & - & PDS/PP & 89,6 & $1,0 \%$ & $3,9 \%$ & $3,8 \%$ & - \\
\hline PSC & 92,5 & $1,4 \%$ & $0,2 \%$ & $0,8 \%$ & - & PDT & 85,9 & $5,5 \%$ & $1,6 \%$ & $1,5 \%$ & - \\
\hline PMDB & 92,0 & $18,9 \%$ & $17,1 \%$ & $11,1 \%$ & $6,3 \%$ & PFL/DEM & 67,5 & $17,3 \%$ & $12,7 \%$ & $14,5 \%$ & $4,1 \%$ \\
\hline PDS/PP & 85,3 & $0,8 \%$ & $3,5 \%$ & $5,6 \%$ & $1,8 \%$ & PSDB & 67,2 & $11,8 \%$ & $9,8 \%$ & $8,4 \%$ & $4,1 \%$ \\
\hline PSDB & 57,8 & $11,7 \%$ & $13,2 \%$ & $17,5 \%$ & $4,5 \%$ & PRONA & 52,3 & - & - & - & - \\
\hline PFL/DEM & 56,6 & $17,0 \%$ & $20,7 \%$ & $16,7 \%$ & $1,8 \%$ & & & & &
\end{tabular}

Fonte: Banco de Dados Legislativos, Cebrap.

Notamos aqui, em grau significativamente maior, que o poder de agenda é limitado aos partidos de oposição, uma vez que ficaram sempre na metade, ou abaixo da proporção que em tese o governo os partidos teriam direito em virtude das cadeiras que ocupam no parlamento - porém, não nulo. Uma rápida olhada nos governos tucanos mostra que lá o Executivo não se mostrava tão duro com a oposição. Notamos aqui que o PFL/DEM é quase totalmente excluído da formatação da agenda. Talvez isso tenha se dado em virtude das indisposições criadas pela recém passada eleição presidencial. Mas para que isso seja verdade, nas demais coalizões do governo de Lula, essa curva deve mudar. 
Tabela 3.5: Geral Lula I (2)

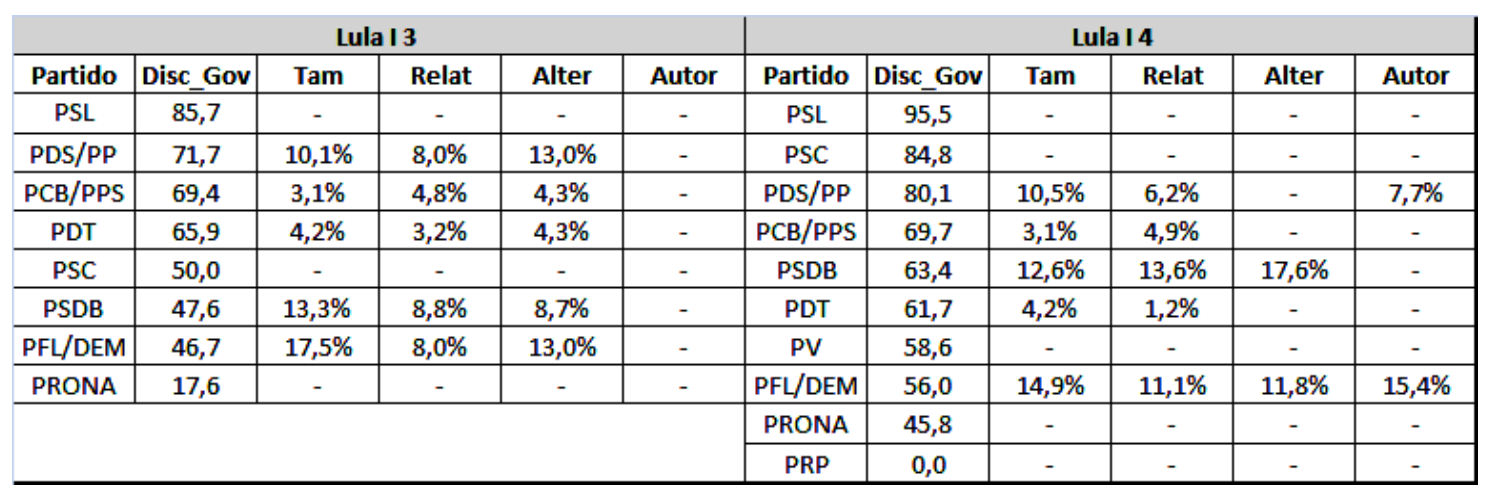

Fonte: Banco de Dados Legislativos, Cebrap.

Cabe destacar que a coalizão "Lula I 3" - como já assinalamos quanto tratamos da autoria das leis - é das menores, e foi nela que estourou o chamado "mensalão". Provavelmente os acirramentos dos ânimos seja aqui responsável pela ausência de proposições aprovadas dos membros da não-coalizão.

No "Lula I 4" é nítida a participação do PFL/DEM participando proporcionalmente ao seu tamanho na construção da agenda. O número expressivo de $15.4 \%$ de tudo que foi proposto indica isso. 
Tabela 3.6: Geral Lula II (1)

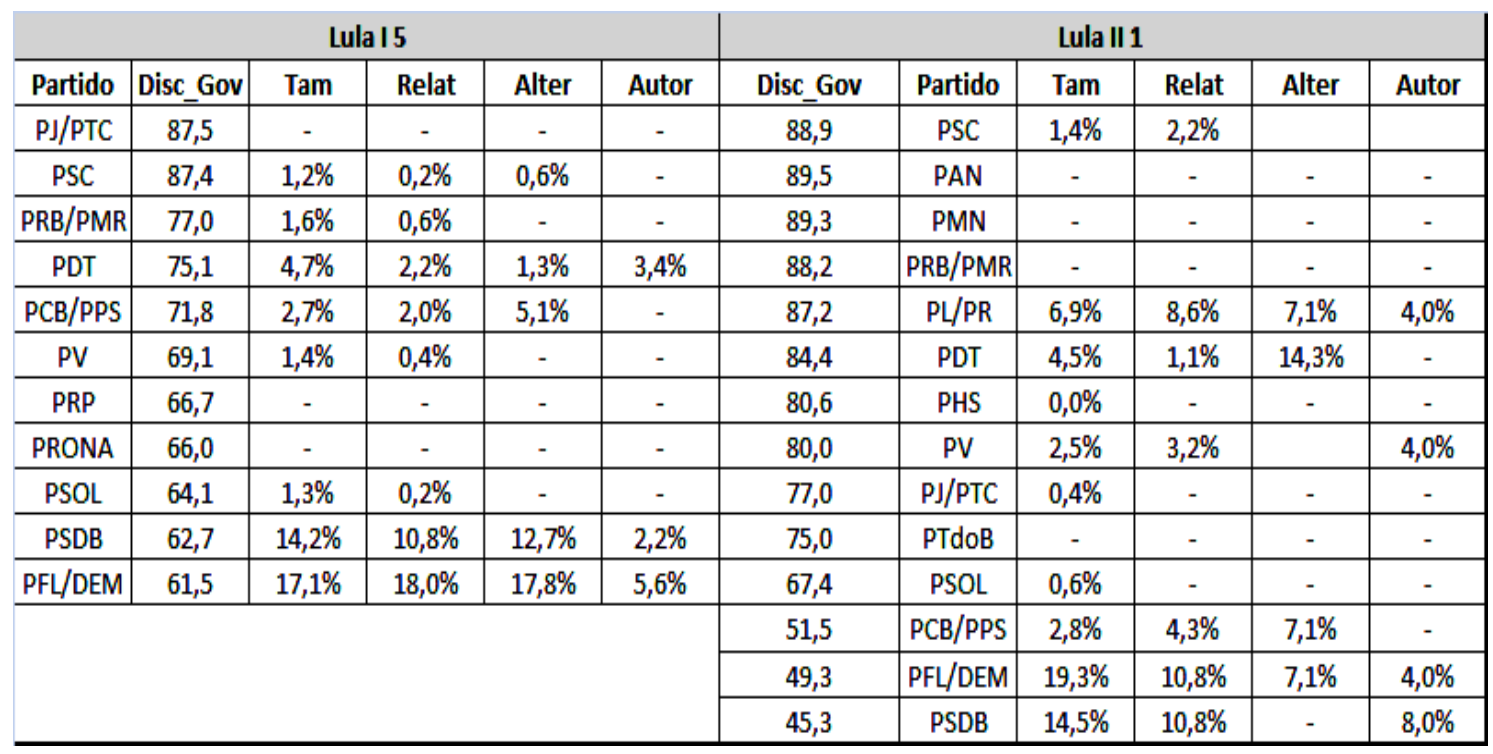

Fonte: Banco de Dados Legislativos, Cebrap.

No final do primeiro governo Lula, como já notamos que havia acontecido no governo FHC, o governo concentra novamente os poderes da pauta via autoria de projetos.

Tabela 3.7: Geral Lula II (2)

\begin{tabular}{c|c|c|c|c|c|} 
Lula II 2 & & & & & \\
\hline Partido & Disc_Gov & Tam & Relat & Alter & Autor \\
\hline PHS & 94,3 & $0,6 \%$ & - & - & - \\
\hline PMN & 93,8 & $0,9 \%$ & $0,5 \%$ & $0,3 \%$ & - \\
\hline PTdoB & 92,5 & - & - & - & - \\
\hline PAN & 90,1 & - & - & - & - \\
\hline PSC & 89,1 & $2,3 \%$ & $1,4 \%$ & $1,6 \%$ & $1,6 \%$ \\
\hline PV & 85,7 & $2,6 \%$ & $0,8 \%$ & $0,6 \%$ & - \\
\hline PRTB & 85,4 & - & - & - & - \\
\hline PJ/PTC & 79,7 & $0,3 \%$ & $0,8 \%$ & $0,3 \%$ & $0,8 \%$ \\
\hline PSOL & 58,2 & $0,6 \%$ & $0,2 \%$ & $0,3 \%$ & \\
\hline PFL/DEM & 57,3 & $15,2 \%$ & $9,5 \%$ & $7,9 \%$ & $1,6 \%$ \\
\hline PCB/PPS & 55,7 & $2,7 \%$ & $1,2 \%$ & $2,5 \%$ & $0,8 \%$ \\
\hline PSDB & 52,5 & $14,4 \%$ & $10,2 \%$ & $10,4 \%$ & $4,7 \%$ \\
\hline
\end{tabular}

Fonte: Banco de Dados Legislativos, Cebrap. 
Por fim podemos notar nessa ultima tabela, que o grau de participação dos partidos usualmente tidos como de oposição (PSDB, PFL/DEM) sofreu um aumento no ultimo mandato petista.

\section{Conclusão}

A série de dados apresentados neste trabalho nos mostra que o sistema político brasileiro opera de maneira a incluir os diferentes atores nas etapas de formulação das políticas, como também a relação entre cadeiras que ocupam e participação que têm ao longo do processo se aproxima da proporcionalidade. Aqui, a variável proporção de cadeiras serve para mostrar como a atuação desses partidos não é nada pequena, e sim é o que se poderia esperar de uma representação proporcional, de um sistema onde a minoria é ouvida. Dentre aqueles atores que se situam fora da coalizão, tanto os partidos normalmente tidos como de oposição, quando os partidos que expressam altas taxas de disciplina em relação ao governo, participam no processo de formulação das leis aprovadas. Não foi encontrada relação direta entre disciplina partidária e participação.

Governar não parece ser tarefa exclusiva da coalizão. E isto pode ser notado nos dados obtidos, na qual fica patente que a participação da não-coalizão é tão significativa nos governos minoritários quanto nos majoritários - onde pese que o governo não dependeria dos partidos situados fora da coalizão de governo para aprovar sua agenda. Se a proporção de participação dos atores se dá na relação próxima com a proporção de cadeiras que ocupam, importa ressaltar que, com exceção dos partidos que ocupam menos que $0,1 \%$ das cadeiras, os demais participam em alguma das etapas do processo.

Sem um grau de consenso e abertura, respeito mutuo entre maioria e minoria, as coisas não funcionariam. Os dados indicam que esse consenso e abertura são maiores do que se poderia supor, em que pese a participação das minorias no processo de tomada de 
decisão. É claro que deve ser dito que, tudo somado, o que foi visto até aqui se resume a um pedaço dos projetos de lei que são apresentados todos os anos no congresso - os aprovados, excluídos aqueles que tratam de matérias exclusivamente orçamentárias (PLNs).

Dentro do modelo analisado os atores participam; temos indicativos de que as divergências são assimiladas, e como fruto disso as políticas de governo são debatidas e formuladas não só pelos partidos que compõem o governo, mas também pelos que estão fora dele. Apesar de nosso sistema dar artifícios para que o governo controle a agenda, isso não significa que ele passe por cima do Legislativo, da oposição ou as minorias os atores têm participação garantida, não só regimentalmente, como empiricamente. 
Anexo 1

Coalizões (1988-2010)

\begin{tabular}{|c|c|c|c|c|c|c|c|c|c|c|}
\hline \multirow{2}{*}{ 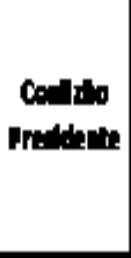 } & \multicolumn{2}{|c|}{ Datacosito } & \multirow{2}{*}{ Petod bo } & \multirow{2}{*}{ Pritodace da } & \multicolumn{2}{|c|}{ Duniso } & \multicolumn{2}{|c|}{ 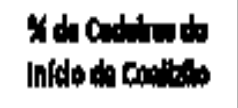 } & \multicolumn{2}{|c|}{ 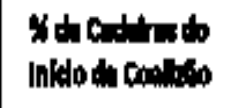 } \\
\hline & L徆 & F & & & D' & DEs & 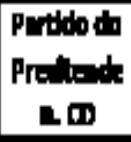 & nilis & $\begin{array}{c}\text { Fartidodo } \\
\text { Frettend } \\
\text { n-sf }\end{array}$ & 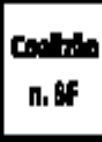 \\
\hline Stmer2 & E- & 14-m: & PMOB & PMDBPFL & $\mathbf{5 2 4}$ & 17 & 41,46 & 的, 27 & 4,2 & 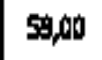 \\
\hline collon 1 & 15-marsen & 12-outen & PAW & PAN - PFL & 211 & 7 & 5,00 & 2,70 & סקه & 2100 \\
\hline $\cot 10$ & 13-04t:-90 & 3) & PFN & PFW - PF +005 & 110 & 4 & 6,00 & 30,51 & 5,5 & 20,10 \\
\hline a.tos & Ifth-91 & $14-\operatorname{bin} 2$ & Pow & PAN -PFL-POS & 498 & 15 & 7,95 & 20 & 6,17 & 92,10 \\
\hline W.1.4 & 15-arse & Solta2 & Piw & PRN -PFL -PDS -PIB -PL & 161 & 6 & 6,16 & 4,15 & 6,17 & 40,70 \\
\hline Fin 1 & $1 \rightarrow$ It & 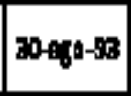 & dpat & $\begin{array}{c}\text { PR-PTd -PWDA -PEDB - } \\
\text { POS }\end{array}$ & 재 & 10 & - & 5,20 & - & 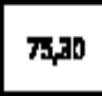 \\
\hline Bumber & $31+40-96$ & $24+5 n-24$ & sinit & $\begin{array}{c}\text { PR -PTd -PMDA - PEDB - } \\
\text { PP }\end{array}$ & 146 & 5 & - & 5,05 & - & 74,10 \\
\hline g-1: & $2 \sin 94$ & a1-dast & dpat & PFL - PADB - POPB P P & 940 & 11 & - & $\mathbf{5 , 4 7}$ & - & 70,40 \\
\hline FHCI1 & 1)mes & 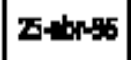 & Pol & PDS -PFL - PMDB -PIB & 190 & 15 & 12,18 & 5,53 & 11,11 & 64,20 \\
\hline FHCI2 & 2starss & aldersis & Pon: & $\begin{array}{c}\text { PQBA -PFL - PMDS -PTB - } \\
\text { PF }\end{array}$ & 979 & $\pi$ & 18,5 & $7, \infty$ & 16,15 & 82,70 \\
\hline Fich1 & 1ytar-s & 5 -mar-az & $\operatorname{pos}$ & PSBD-PFL-PMDB-PP & 115 & 象 & 18,32 & 9,01 & 1481 & Th.30 \\
\hline Fict2 & $6 m a 2$ & a1-dand & Pol & POB - PMDB - PP & 800 & 9 & 18,18 & 45,00 & 17,28 & 46,90 \\
\hline Iulal1 & $1 y=0$ & 2y-ans & PT & $\begin{array}{c}\text { FT -PL-PCAB - PSO - PTE - } \\
\text { PDT PPS-PY }\end{array}$ & 595 & 19 & 17,99 & 40,54 & 9, & $\mathbf{x g y}$ \\
\hline | & 2zfan-as & 31-jen-ng & F & 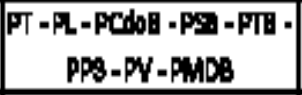 & 774 & 12 & 17,74 & sis; & 17,2 & Exald \\
\hline whal: & Ifen-00 & 19m:-05 & FT & 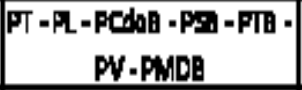 & 107 & 4 & 17,74 & 5,14 & 16,15 & 50,10 \\
\hline Iulalu & $20-m a \mid-105$ & 2yul-os & PT & $\begin{array}{c}\text { PT -PL-PCAB -Pid -PIB - } \\
\text { PMCB }\end{array}$ & 的 & 2 & 17,74 & 38 & 16,05 & 54,90 \\
\hline Lulals & 20 & 91-deass & PT & $\begin{array}{c}\text { F -PL-PCAB - PSO -PTE - } \\
\text { PMDA -PP }\end{array}$ & $\mathbf{5 2 5}$ & 19 & 17,54 & 69,40 & 15,5 & 56,80 \\
\hline |r||l 1 & 1]an-n & $1+\operatorname{tar}-07$ & F & $\begin{array}{c}\text { P - PL-PCdoB -PS -PTE - } \\
\text { PMDB - PP }\end{array}$ & 80 & $\mathbf{a}$ & 15,89 & $\mathbf{s}, \mathbf{6 0}$ & 14,51 & 61,70 \\
\hline Linlillz & $2-8$ are-07 & $a 1-40=10$ & FT & 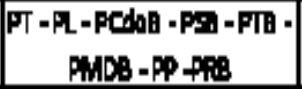 & 130 & 45 & 15,90 & TI, & $12,5 \%$ & $\infty, A$ \\
\hline
\end{tabular}

Fonte: Banco de Dados Legislativos Cebrap, extraído de Figueiredo (2007) e atualizado até 2010. 
Anexo 2

\section{Área Temáticas}

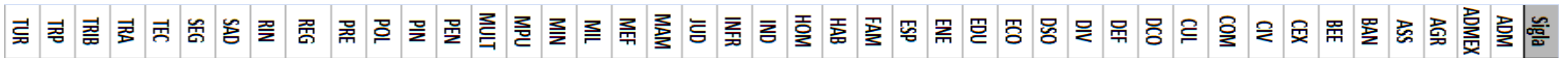

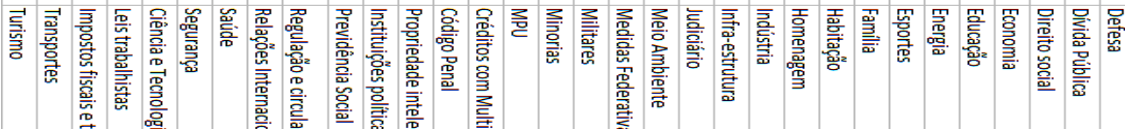
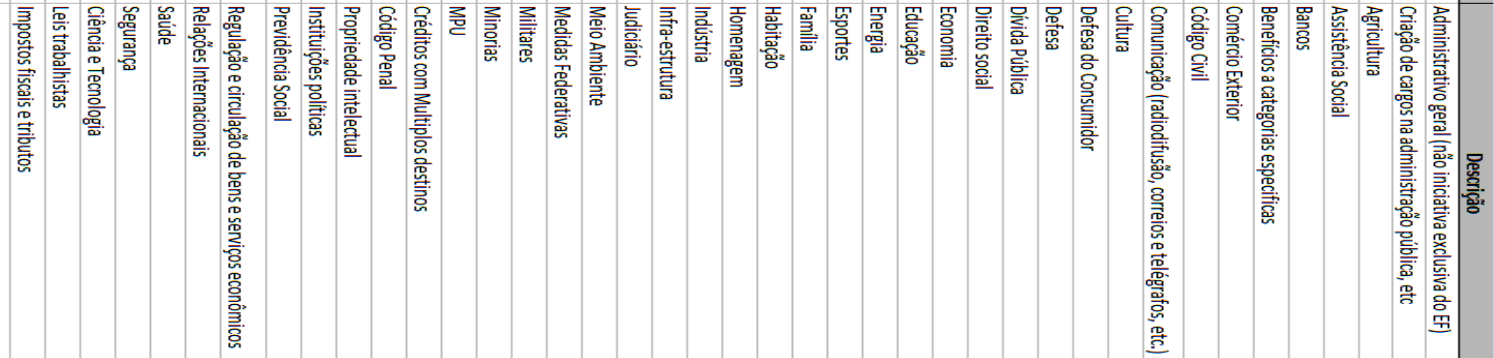

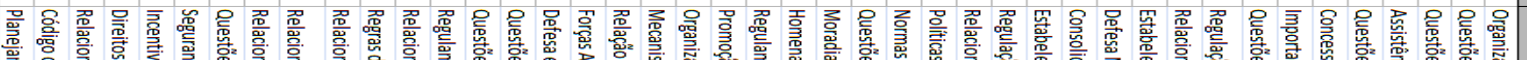

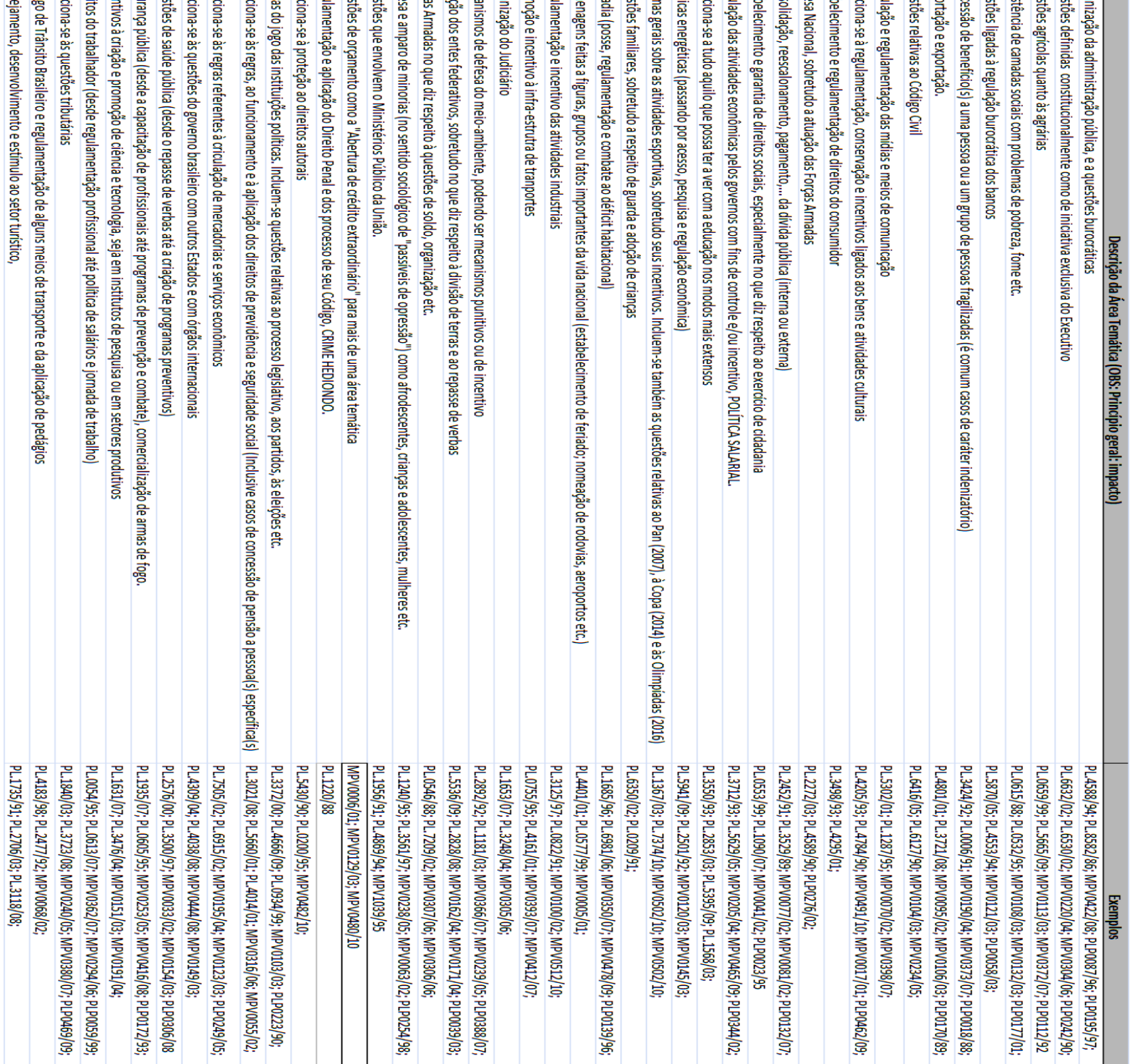

\section{Anexo 3}


Participação da não-coalizão, por partido

\begin{tabular}{c|c|c|c|c|c|c|c|c|c|c|c|}
\multicolumn{9}{|c|}{ Sarney 2 } & \multicolumn{7}{c|}{ Collor 1 } \\
\hline Partido & Disc_Gov & Tam & Relat & Alter & Autor & Partido & Disc_Gov & Tam & Relat & Alter & Autor \\
\hline PLP & 100,0 & - & - & - & - & PJ/PTC & 100,0 & - & - & - & - \\
\hline PPB_1 & 100,0 & - & - & - & - & PSD & 100,0 & $0,2 \%$ & - & - & - \\
\hline PDC & 89,7 & $4,2 \%$ & $1,6 \%$ & - & $0,9 \%$ & PSC & 95,2 & - & - & - & - \\
\hline PTR & 85,7 & - & - & - & - & PTdoB & 94,7 & - & - & - & - \\
\hline PL/PR & 80,2 & $2,9 \%$ & $1,9 \%$ & $1,3 \%$ & $0,9 \%$ & PDS/PP & 93,6 & $5,9 \%$ & $4,6 \%$ & $5,6 \%$ & $2,9 \%$ \\
\hline PSD & 80,0 & - & - & - & - & PTR & 93,3 & $0,6 \%$ & $0,7 \%$ & - & - \\
\hline PDS/PP & 77,3 & $5,5 \%$ & $6,7 \%$ & $6,5 \%$ & $4,7 \%$ & PDC & 92,3 & $3,1 \%$ & - & - & - \\
\hline PTB & 74,6 & $4,9 \%$ & $4,0 \%$ & - & $0,9 \%$ & PL/PR & 90,5 & $2,9 \%$ & $1,3 \%$ & - & - \\
\hline PJ/PTC & 74,5 & - & - & - & $2,8 \%$ & PTB & 89,8 & $5,5 \%$ & $2,0 \%$ & $5,6 \%$ & - \\
\hline PSC & 69,2 & $0,4 \%$ & $1,1 \%$ & $1,3 \%$ & - & PRS & 89,5 & $1,4 \%$ & $2,0 \%$ & - & - \\
\hline PSDB & 50,1 & $10,2 \%$ & $11,0 \%$ & $15,6 \%$ & $12,3 \%$ & PST & 83,9 & - & - & - & - \\
\hline PSB & 35,8 & $1,6 \%$ & $0,3 \%$ & - & $0,9 \%$ & PMDB & 68,3 & $24,9 \%$ & $38,6 \%$ & $27,8 \%$ & $17,1 \%$ \\
\hline PDT & 25,4 & $4,4 \%$ & $5,6 \%$ & $5,2 \%$ & $2,8 \%$ & PRP & 66,7 & - & - & - & - \\
\hline PCB/PPS & 23,1 & - & - & - & - & PSDB & 42,6 & $12,4 \%$ & $15,0 \%$ & $27,8 \%$ & $11,4 \%$ \\
\hline PMN & 20,0 & - & - & - & - & PDT & 6,2 & $7,1 \%$ & $6,5 \%$ & - & $5,7 \%$ \\
\hline PT & 16,7 & $3,2 \%$ & $0,5 \%$ & $1,3 \%$ & $2,8 \%$ & PSB & 1,0 & $2,5 \%$ & $1,3 \%$ & - & - \\
\hline PCdoB & 9,1 & $1,2 \%$ & $0,3 \%$ & $1,3 \%$ & $0,9 \%$ & PCdoB & 0,8 & $1,2 \%$ & $0,7 \%$ & - & - \\
\hline PCN & 0,0 & - & - & - & - & PT & 0,3 & $3,3 \%$ & $2,6 \%$ & $5,6 \%$ & $2,9 \%$ \\
\hline PP_1 & 0,0 & - & - & - & - & PCB/PPS & 0,0 & $0,6 \%$ & $1,3 \%$ & - & $2,9 \%$ \\
\hline PRONA & 0,0 & - & - & - & - & PMN & 0,0 & - & - & - & - \\
\hline PRP & 0,0 & - & - & - & - & & & & & & \\
\hline PST & 0,0 & - & - & - & - & & & & & & \\
\hline & & & & & & & & & \\
\hline
\end{tabular}

Fonte: Banco de Dados Legislativos, Cebrap.

Collor 2

Collor 3

\begin{tabular}{c|c|c|c|c|c|c|c|c|c|c|c|}
\hline Partido & Disc_Gov & Tam & Relat & Alter & Autor & Partido & Disc_Gov & Tam & Relat & Alter & Autor \\
\hline PCB/PPS & 55,6 & $0,6 \%$ & $1,0 \%$ & - & - & PTR & 85,3 & $1,7 \%$ & $0,5 \%$ & - & $0,8 \%$ \\
\hline PTdoB & 83,3 & - & - & - & - & PSC & 83,8 & $1,0 \%$ & $0,5 \%$ & $1,2 \%$ & - \\
\hline PRS & 80,6 & $1,4 \%$ & $1,0 \%$ & - & - & PV & 82,4 & $0,2 \%$ & $0,2 \%$ & - & - \\
\hline PMDB & 76,0 & $23,8 \%$ & $29,7 \%$ & $23,7 \%$ & - & PL/PR & 79,2 & $3,1 \%$ & $0,8 \%$ & $0,6 \%$ & $0,8 \%$ \\
\hline PDC & 67,7 & $3,5 \%$ & $2,0 \%$ & $5,3 \%$ & - & PMN & 78,8 & - & - & - & - \\
\hline PSC & 66,7 & - & - & - & - & PDC & 75,8 & $3,5 \%$ & $3,8 \%$ & $4,3 \%$ & $0,8 \%$ \\
\hline PSD & 66,7 & - & - & - & - & PST & 74,4 & $1,4 \%$ & $0,7 \%$ & $1,2 \%$ & - \\
\hline PTR & 66,7 & - & - & - & - & PRS & 74,0 & - & - & - & - \\
\hline PTB & 66,0 & - & - & - & - & PSD & 72,7 & - & - & - & - \\
\hline PST & 61,1 & - & - & - & - & PTB & 72,6 & $8,4 \%$ & $6,1 \%$ & $3,7 \%$ & $4,1 \%$ \\
\hline PSDB & 61,0 & $12,2 \%$ & $17,8 \%$ & $18,4 \%$ & - & PMDB & 67,2 & $23,1 \%$ & $36,6 \%$ & $32,5 \%$ & $20,3 \%$ \\
\hline PL/PR & 59,4 & $2,9 \%$ & $1,0 \%$ & - & - & PSDB & 49,1 & $8,9 \%$ & $9,3 \%$ & $11,7 \%$ & $10,6 \%$ \\
\hline PDT & 53,2 & $7,2 \%$ & $6,9 \%$ & $7,9 \%$ & - & PDT & 43,8 & $7,6 \%$ & $7,3 \%$ & $9,2 \%$ & $7,3 \%$ \\
\hline PMN & 50,0 & $1,2 \%$ & $3,0 \%$ & - & - & PSB & 38,7 & $2,1 \%$ & $0,7 \%$ & $0,6 \%$ & - \\
\hline PSB & 33,7 & $3,1 \%$ & $4,0 \%$ & $5,3 \%$ & - & PCB/PPS & 37,0 & $0,6 \%$ & $0,5 \%$ & - & - \\
\hline PCdoB & 33,3 & $1,2 \%$ & $1,0 \%$ & - & - & PT & 36,3 & $7,0 \%$ & $4,1 \%$ & $7,4 \%$ & $7,3 \%$ \\
\hline PT & 32,2 & $3,4 \%$ & - & $2,6 \%$ & - & PCdoB & 32,6 & $1,0 \%$ & $0,2 \%$ & $0,6 \%$ & - \\
\hline PRP & - & - & - & - & - & & & & & & \\
\hline
\end{tabular}

Fonte: Banco de Dados Legislativos, Cebrap. 


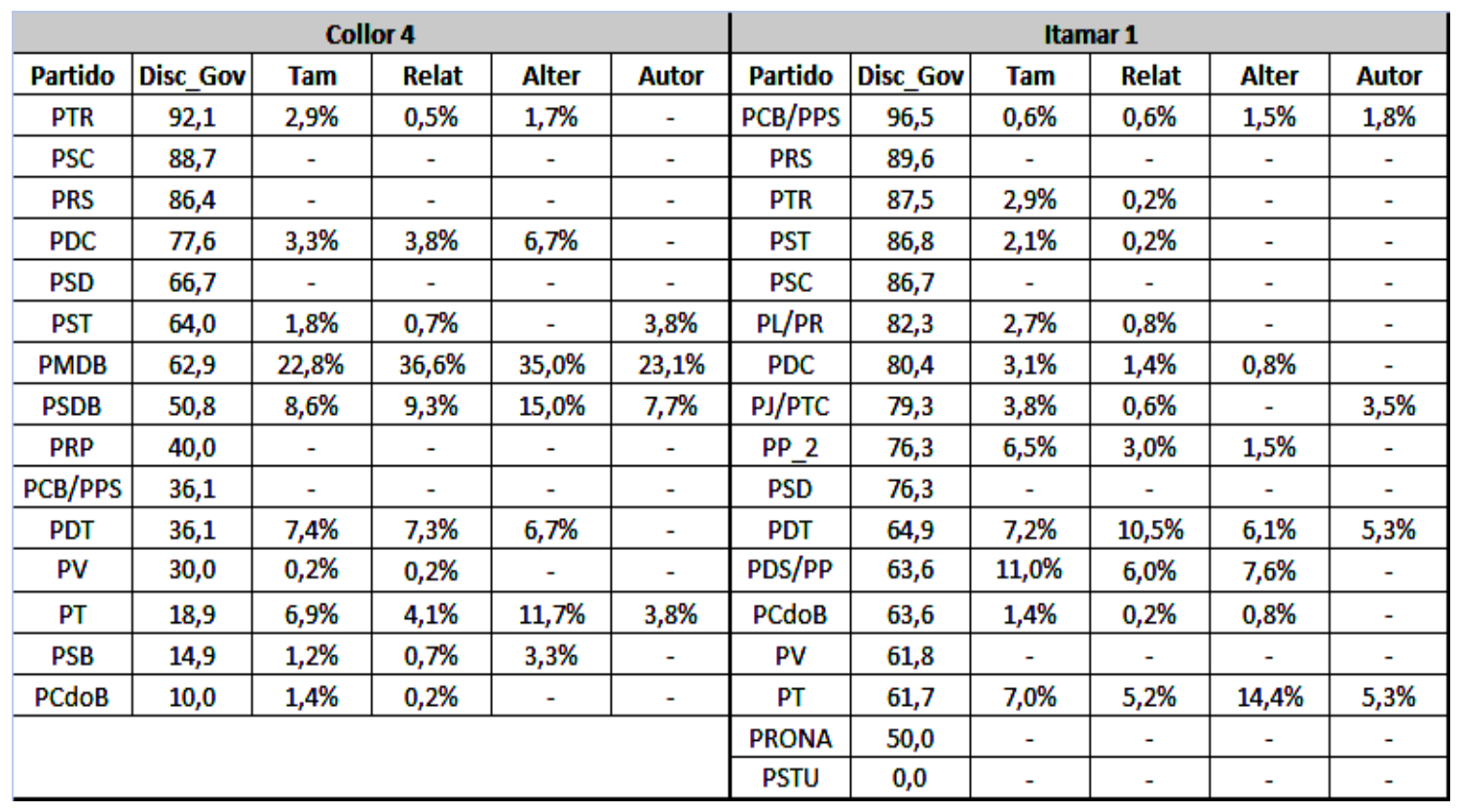

Fonte: Banco de Dados Legislativos, Cebrap.

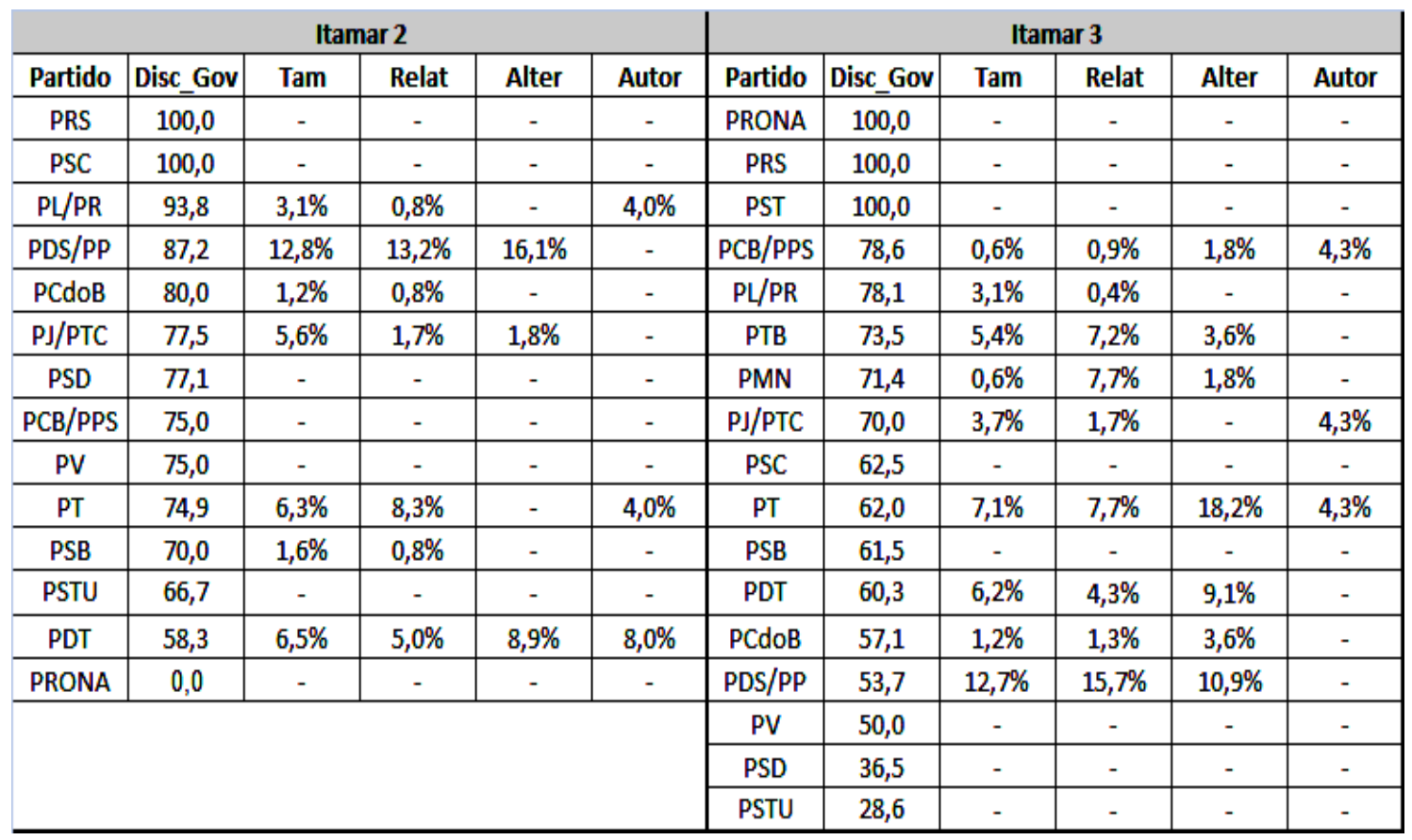

Fonte: Banco de Dados Legislativos, Cebrap.

\section{Bibliografia}


ABRANCHES, Sérgio. Presidencialismo de coalizão: o dilema institucional brasileiro.

Dados, Rio de Janeiro: IUPERJ, vol. 31, no 1, 1988, pp. 3-55.

AMES, Barry. (2001), The Deadlock of Democracy in Brazil. University of Michigan Press. Michigan.

AMORIM NETO, Octavio. O Brasil, Lijphart e o modelo consensual de democracia. In: INÁCIO, Magna; RENNO, Lúcio. Legislativo brasileiro em perspectiva comparada. Belo Horizonte: Editora UFMG, 2009.

ANASTASIA, Fátima et al. De lá para cá: As condições e as instituições da democracia depois de 1988. In MELO, Carlos Ranulfo\& SÁEZ, Manuel Alcântara (orgs). A democracia brasileira: balanços e perspesctivas para o século 21. Belo Horizonte: Editora UFMG, 2007.

ANASTASIA, Fátima. ; MELO, C. R. F. ; SANTOS, Fabiano . Governabilidade e Representação Pólítica na América do Sul. 1. ed. Rio de Janeiro e São Paulo: Fundação Konrad Adenauer e Fundação Unesp Ed., 2004. v. 01. 207 p.

ANASTASIA, Fátima. ; NUNES, F. . A Reforma da Representação. In: AVRITZER, Leonardo; ANASTASIA, Fátima. (Org.). Reforma Política no Brasil. 1 ed. Brasília / Belo Horizonte: PNUD / Editora UFMG, 2006, v. 1, p. 17-33.

ABRUCIO, Luiz Fernando. (1998), Os Barões da Federação os governadores e a redemocratização brasileira. São Paulo, Editora Hucitec.

AMORIM NETO, Octavio. (2000), Presidential cabinets, electoral cycles, and coalition discipline in Brazil. Dados, vol 43, n. 3.

. (2006) "The Presidential Calculus: Executive Policy

Making and Cabinet Formation in the Americas", Comparative Political Studies, vol. 39 , n. 4, p.1-26.

BRASIL. (2006), Constituição da República Federativa do Brasil: texto consolidado até a Emenda Constitucional $\mathrm{n}^{\mathrm{o}} 53$ de 19 de dezembro de 2006. Disponível em: http://www.senado.gov.br/sf/legislacao/const/ . Acesso em: 23 set. 2007.

BINDER, Sarah. A. (1997), Minority Rights, Majority Rule: Partisanship and The Development of Congress, New York: Cambridge University Press. 
CÂMARA DOS DEPUTADOS. Regimento Interno: Resolução n ${ }^{\circ} 17$ de 1989. Disponível em: http://www2.camara.gov.br/internet/legislacao/RegInterno.pdf>. Acesso em: 01 out. 2007.

CHEIBUB, J. A., PRZEWORSKI, A. e SAIEGH, S. "Governos de Coalizão nas Democracias Presidencialistas e Parlamentaristas”. Dados, vol.45, n.2, 2002, p.187-218.

COX, Gary W. e MCCUBBINS, Mathew D. (1993) Legislative leviathan: party government in the House. Berkeley, University of California Press.

FIGUEIREDO, Argelina. (2007). Government Coalitions in Brazilian Democracy." Brazilian Political Science Review 1(2):182\{216.

FIGUEIREDO, Argelina \& LIMONGI, Fernando. (1995), "Mudança constitucional, desempenho do Legislativo e consolidação institucional". Revista Brasileira de Ciências Sociais, 10 (29): 175-200.

. (1996) "Congresso Nacional: organização, processo legislativo e produção legal". Cadernos de Pesquisa CEBRAP, São Paulo, $n^{\circ} 5$.

. (1998) "Bases Institucionais

do Presidencialismo de Coalizão". Lua Nova, nº 44, pp. 81-106.

(1999) Executivo $e$

Legislativo na Nova Ordem Constitucional. Fundação Getúlio Vargas Editora, Rio de Janeiro.

(2008) Política

orçamentária no presidencialismo de coalizão. 1. ed. Rio de Janeiro: Editora FGV, v. 1. . "Poder de Agenda e

Políticas Substantivas" in INÁCIO, Magna e RENNÓ, Lúcio (Org.). Legislativo Brasileiro em Perspectiva Comparada, Belo Horizonte: Editora UFMG, 2009, p.77104. 
FREITAS, Andréa (2009) "Migração partidária na Câmara dos Deputados". [S.1.]. Dissertação de Mestrado. Departamento de Ciência Política da Universidade de São Paulo.

FREITAS, Rafael. (2010) Poder de agenda e participação legislativa no presidencialismo de coalizão brasileiro. 2010. 126 p. Dissertação de Mestrado Faculdade de Filosofia, Letras e Ciências Humanas, Universidade de São Paulo, São Paulo.

FREITAS, Rafael; MEDEIROS, Danilo; MOURA, Samuel. (2008) "Padrões de Atuação das Comissões do Congresso Nacional (1988-2006)". In: XXXII Encontro Nacional da ANPOCS, 2008, Caxambu - MG. XXXII Encontro Nacional da ANPOCS.

HELLER, William B. (2001) "Making Policy Stick: Why the Government Gets What It Wants in Multiparty Parliaments”. American Journal of Political Science, vol. 45, n. 4, p. $780-798$.

HUBER, John. (1996). Rationalizing Parliament: legislative institutions and party politics in France. Cambridge University Press.

HUBER, John e MCCARTHY, Nolan. (2001) “Cabinet Decision Rules and Political Uncertainty in Parliamentary Bargaining”. American Political Science Review, vol. 95, n. 2 , p. $345-360$.

INÁCIO, Magna. (2008), "Mudança procedimental, oposições e obstrução na Câmara dos Deputados". Texto apresentado no $6^{\circ}$ Encontro da $A B C P$, realizado em Campinas.

JACOBSON, Gary C. (1992), The Politics of Congressional Elections. New York, HarperCollins.

KERROUCHE, Eric. (2006) "The French Assemblée Nationale: the case of a weak legislature?” The Journal of Legislative Studies, vol $\underline{12}$, n. $\underline{3 \& 4}$, p. 336-365.

KREHBIEL, K. "Spatial models of political choice”. Legislative Studies Quarterly. vol. 8, 1988, pp. 259-319. 
LAMOUNIER, Bolivar. (1994), A Democracia Brasileira de 1985 à Década de 90: A Síndrome da Paralisia Hiperativa. Governabilidade, Sistema Político e Violência Urbana. J. P. R. Velloso. Rio de Janeiro.

- "Estrutura institucional e governabilidade na década de 1990”. In REIS VELLOSO, João Paulo dos. O Brasil e as reformas políticas. Rio de Janeiro: José Olympio, 1992.

LOUREIRO, M. R. 2001. Instituições, política e ajuste fiscal : o Brasil em perspectiva comparada. Revista Brasileira de Ciências Sociais, Rio de Janeiro, v. 16, n. 47, p. 7596, out.

MAINWARING, Scott. (1991) "Políticos, Partidos e Sistemas Eleitorais". Novos Estudos CEBRAP, São Paulo, nº 29.

(1999), Rethinking Party Systems in the ThirdWave of Democratization: The Case of Brazil. Stanford, Stanford University Press.

MAINWARING, S.; SHUGART, M. (1997). Presidentialism and Democracy in Latin America. Cambridge University Press.

MARTIN, Lanny. (2004) “The Government Agenda in Parliamentary Democracies". American Journal of Political Science Vol. 48, No. 3, pp. 445-461.

MARTIN, Lanny e VANBERG, Georg. (2004) "Policing the Bargain: Coalition Government and Parliamentary Scrutiny." American Journal of Political Science vol. 48, p. $13-27$. . (2005) "Coalition Policymaking and Legislative Review". American Journal of Political Science, vol. 99, n. 1, p. 93-106.

MAYHEW, David. (1974). Congress: The electoral connection. New Haven: Yale University Press.

MATTSON, Ingvar e STROM Kaare. (1995) "Parliamentary committees", in Herbert Döring (org.), Parliaments and majority rule in Western Europe, Nova York, St. Martin's Press. 
MCCARTHY, Nolan, POOLE, Keith T. \& ROSENTAHL, Howard. (2001). The Hunt for Party Discipline in Congress." The American Political Science Review 95(3):673\{687.

MOURA, Samuel; FREITAS, Rafael; MEDEIROS, Danilo. "Padrões de Atuação das Comissões do Congresso Nacional (1988-2006)". In: XXXII Encontro Nacional da ANPOCS, 2008, Caxambu - MG. XXXII Encontro Nacional da ANPOCS, 2008.

PALERMO, Vicente. (2000) "Como se governa o Brasil? O debate sobre instituições políticas e gestão de governo". Dados, 2000, vol.43, n.3, p.521-557.

PEREIRA, Carlos \& MUELLER, Bernardo. (2000) "Uma teoria da preponderância do poder Executivo: o sistema de comissões no Legislativo brasileiro". Revista Brasileira de Ciências Sociais, vol. 15, $\mathrm{n}^{\circ} 43$.

POWER, T. J; ZUCCO, C. (2009) "Estimating ideology of Brazilian Legislative parties, 1990 - 2005: a research communication." Latin American Research Review, vol. 44, $\mathrm{n}^{\circ}$ 1, p.218-246.

RABELO SANTOS, Lourimar (2009), “Oposiçaõ e Obstrução na CÂmara dos Deputados”. Instituto Universitário de Pesquisas do Rio de Janeiro (Iuperj).

REIS, B. P. W. (2007), "O presidencialismo de coalizão sob pressão: da formação de maiorias democráticas à formação democrática de maiorias". Revista Plenarium, 4 (4): 80-103, Câmara dos Deputados.

RICCI, Paolo. (2003), “O conteúdo da produção legislativa brasileira: leis nacionais ou políticas paroquiais?”. Revista Dados, vol.46, no.4, p.699-734.

SAMUELS, David. (2003), “A economia política da reforma macroeconômica no Brasil, 1995-2002”. Revista Dados, vol.46, no.4, p.805-835.

SANTOS, Fabiano. (1997), "Patronagem e Poder de Agenda na Política Brasileira". Revista Dados, vol. 40, nº 3, pp. 465-492.

. (1999), "Instituições eleitorais e desempenho do presidencialismo no Brasil". Revista Dados, vol. 42, n 1, Rio de Janeiro. (2006). “Em defesa do presidencialismo de coalizão", em 
Gláucio Ary Dillon Soares e Lucio R. Rennó (orgs.), Reforma Política: Lições da História Recente, 281-95. Rio de Janeiro: Ed. FGV.

SANTOS, Wanderley Guilherme dos. Crise e Castigo: partidos e generais na politica brasileira. São Paulo: Vértice/IUPERJ, 1987.

SARTORI, Giovanni. (1996), Engenharia Constitucional - como mudam as constituições. Brasília, UNB.

SHEPSLE, Kenneth e WEINGAST, Barry. (1987) "Institutional foundations of committee power". American Political Science Review, vol. 81, p. 85-104.

SMITH, Steven S. e DEERING, Christopher J. (1997) Committees in Congress ( $3^{\mathrm{a}}$ ed.). Washington, D.C., Congressional Quarterly In.

SOUZA, Márcia Teixeira de. (2003), “O processo decisório na Constituição de 1988: práticas institucionais". Revista Lua Nova, nº 58, pp. 37-60.

THIES, Michael. (2000) "On the Primacy of Party in Government: Why Legislative Parties Can Survive Part y Decline in the Electorate." In DALTON, $R$ and WATtenberg, M. (eds)., Parties without Partisans: Political Change in Advanced Industrial Democracies. Oxford: Oxford University Press.

ZUCCHINI, Giampaolo, (1986). Verbete sobre a oposição. In: BOBBIO, Norberto et al. (orgs.). Dicionário de política. $2^{\mathrm{a}}$ ed. Brasília: Editora UnB, p. 846-851

ZUCCO \& LAUDERDALE. (2011) Distinguishing Between Influences on Brazilian Legislative Behavior. Legislative Studies Quarterly, 36:3, 363-396. 